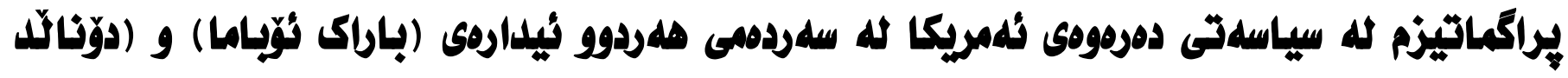
ترمبه)

\author{
(ليَّكوّلَينهوديلهى سياسيى شيكاريى بهراوردكارانهيله )
}

\section{هيَما نيازى حمد}

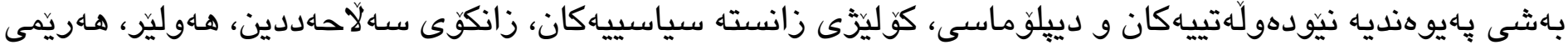
كوردستان، عيّراق. Hema.niazy@yahoo.com : ئمهيل:

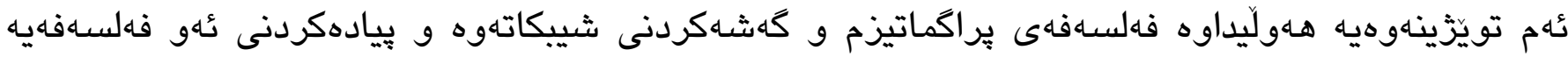
لهسهر ئاستى سياسهتى دهرهوهى ئهميكا له كابينهكانى هـردوو سـاروكى ئهمريكا (باراك ئوباما) و (دونالد ترهمب) دا بهشيّوهيهكى بهراوردكارانه بخاته بهر شيكردنهوه و ليكولينهوه.

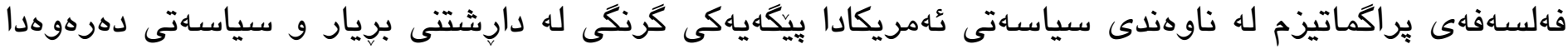
هـبووه و ويادهكردنيشى له نيّوان ئيدارهى (باراك ئزياما) و (دوّنالد ترهمب) له شيّوه و ميكانيزمى جياوازدا بهرجهستهبووه، كه تيكّهيثتن لهو روانكه و ئاراسته سياسييه، هاوكاره بو زيادكردنى تيكاهيشتيك لهبارهى دارشتن و بيادهكردنى سياساتى دهرهوهى ئهمريكا.

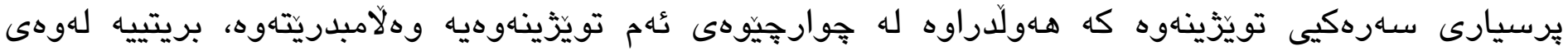
جياوازييه سـرهكى و ديارهكانى سوودوهركرتن و ييادهكرنى يراكماتيزم له نيّوان هـريهك له ئيدارهكانى (ئوناما) و (ترهمب) جִون له سياسهتى دهرهوهى ئهمريكادا رهنكيداوهتهوه؟ له تويَّينهوهكها كريمانهى ئهوه كراوه كه بِراكماتيزم به كَثتى له سياسهتى دهرهوهى ئهمريكادا بو بِاراستنى

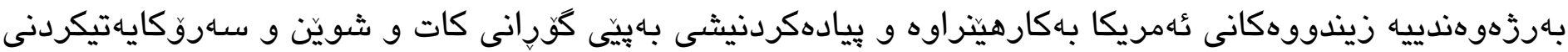
ئهمريكا، كُورانى بهاهـارداهاتووه.

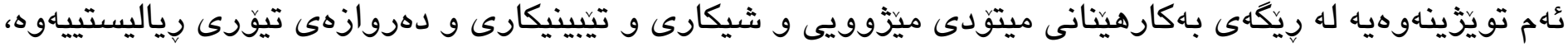
كاهيثتووهته ئهو دهرئهنجامهى كه بِراكماتيزم له سهردهمى ئيدارهى (باراك ئزياما) له شيّوهى هيَّى زيرهك و شاراوه و نهرمدا خوّى بهرجاستهكرووه كه سهربارى خواستى ياراستنى بهرزهوهندييهكانى ئهمريكا، ئهكتهر و 


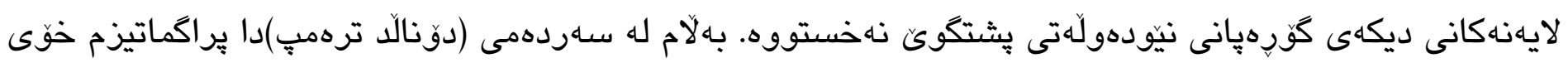

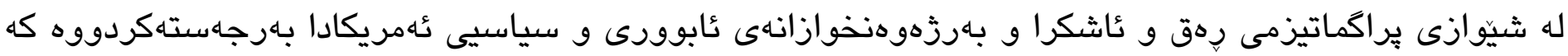

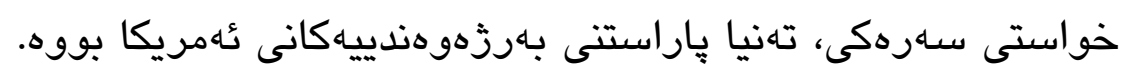

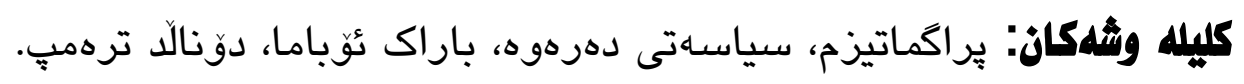

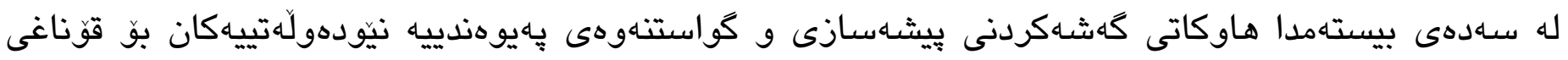

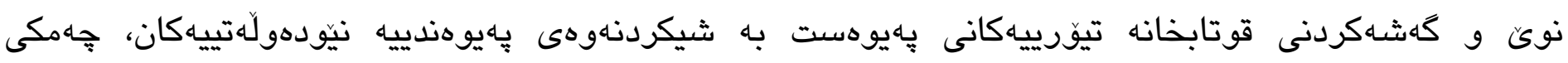

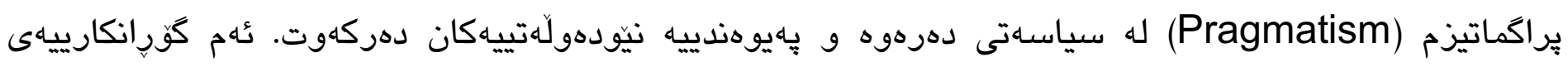

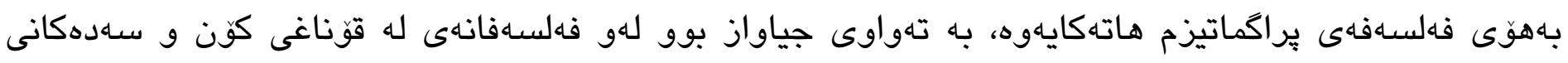

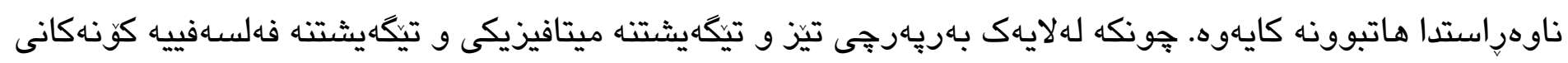

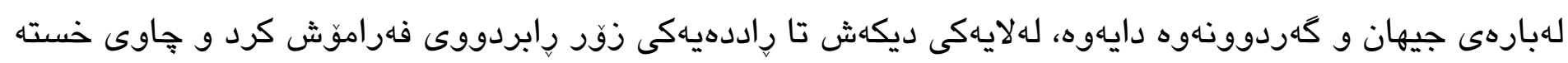

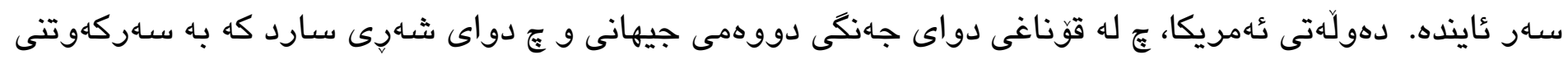

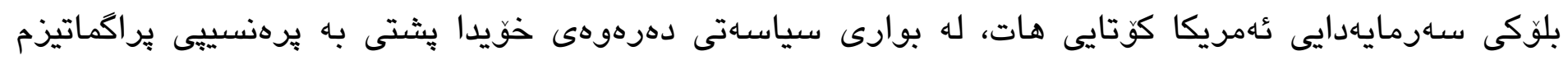

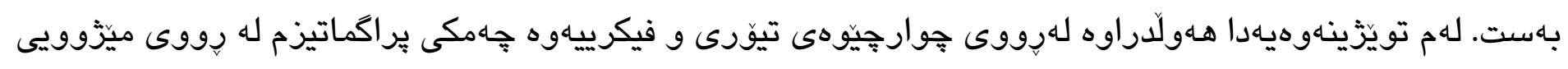

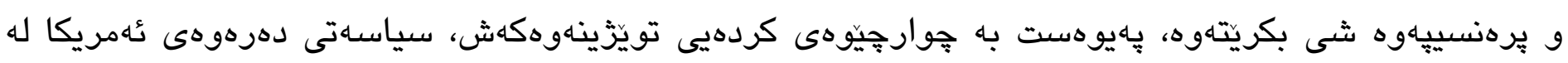

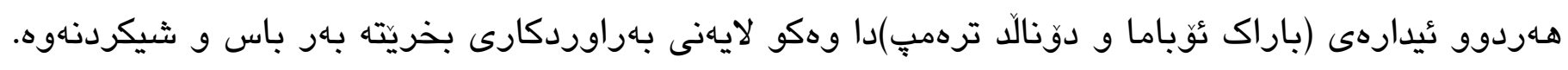

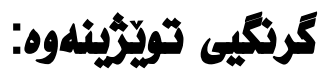

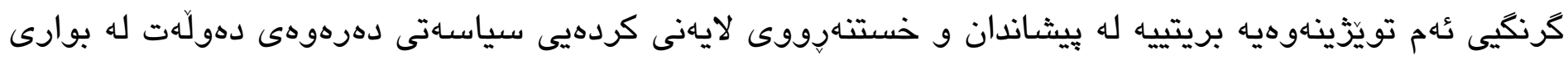

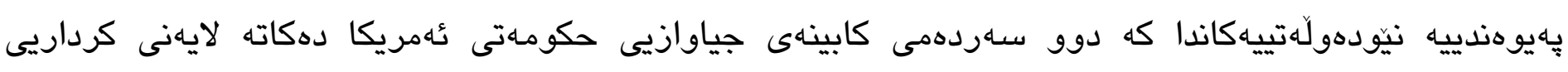

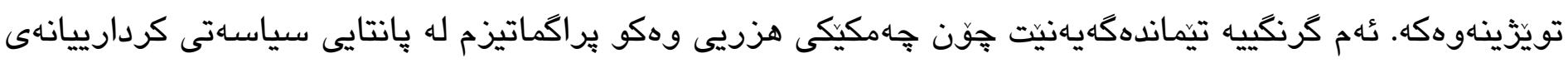

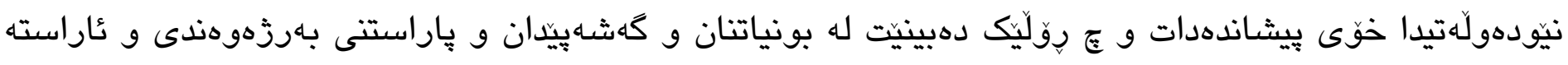

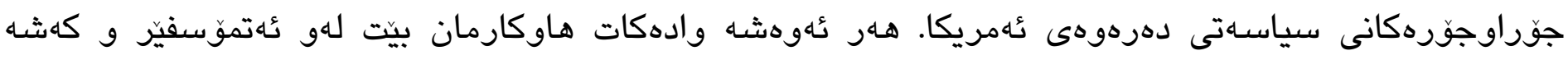

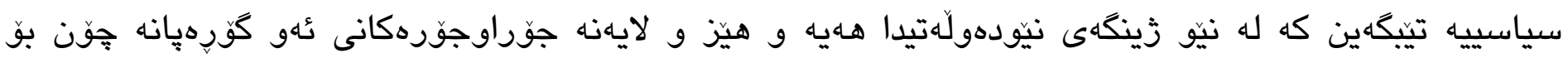
باهديهينانى ئهو ئامانجه سياسييانه له هـاسولَدان. 


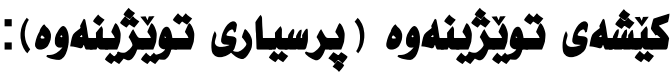

برسيارى سارهكيى تويَزينهوهكهان بريتييه لهوهى: بِراكماتيزم جِون له ههريهك له كابينهانى (باراك ئوباما و

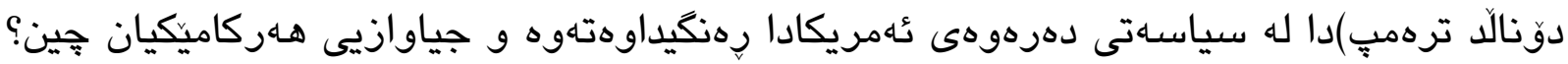

\section{كريماثلهى تُوِّرِينهوه:}

كريمانهى تويّزينهوهكهمان بريتييه له : بِراكماتيزم له سياسهتى دهرهوهى ئهريكادا رِوَلِيَكى بهرجاوى بينيوه، ئهوهش

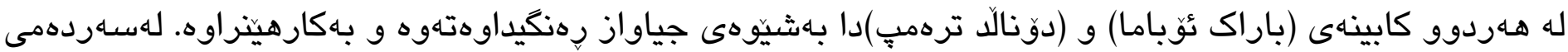

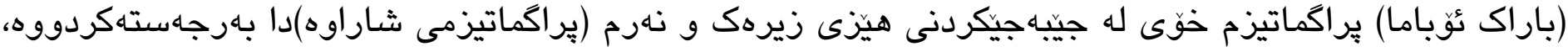
بهلاّم له سـردهمى (دوّنالد ترهمب)دا بِراكماتيزم خوى له بهديهينانى بهرزهوهنديى تاكلايهنهى ئابوورى و سياسى ئهمريكا (براكماتيزمى ئاشكرا و زهق) بهرجهاهتهردودوه.

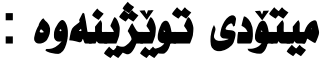

لهم تويّزينهوهيهدا، به لهبهرجاوكرتنى بنهما رِهسهن و زانستييهكان جهاند ميتوديَك بهكارهاتوون: ميتودى شيكارى: يشتبهست به زانيارى و بنهما لوزّيكييهكانى شيكردنهوه، تويَّهر هـولَدهدات بهشيّوهيهكى زانستى و بناماكانى شيكردنهوه، روونكردناوهى ورد له بارهى ناوهروكى تويزّينهوهكه يِيشكهشبكات و تايبهتمهنديى بابهتيبوونيش يشتكوىن نهخات.

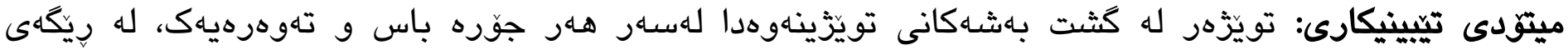

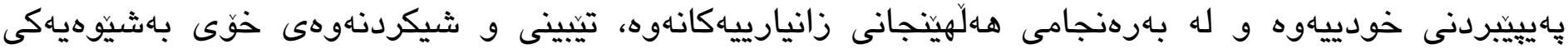
سنووردار و بهئاكايانه سهاربارى بابهتهكان كردووه.

دهروازهى تيوّرى: لهرووى تيوّرييهوه تويَزينهوهكه زياتر بشت به دهروازهى تيوّريى رياليستى كلاسيك و رياليزمى

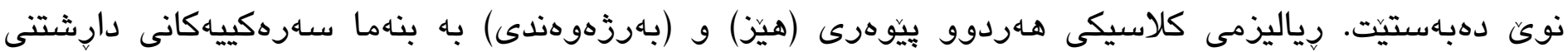
سياسهتى دهرهوه و دابينكردنى ئامانجه نيشتمانييككان ليككداتهوه و رياليزمى نويّش برسى مانهوهى دهولَّت له

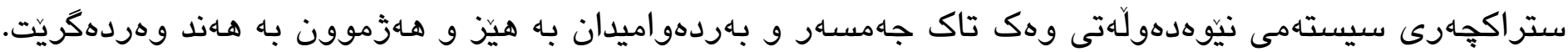

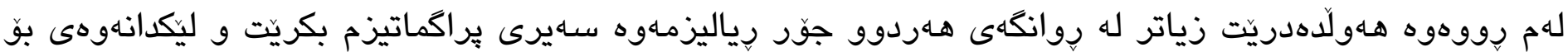
بكريّت. 


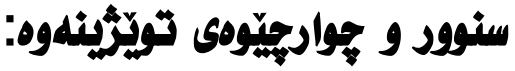

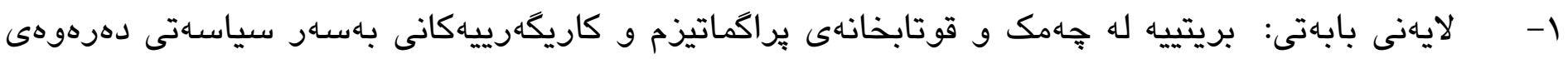

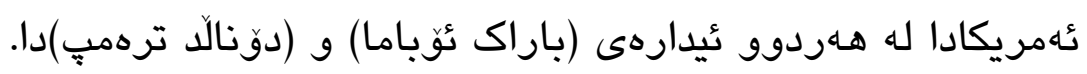

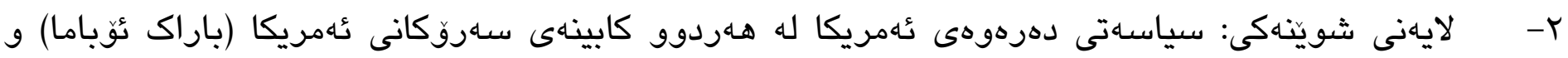

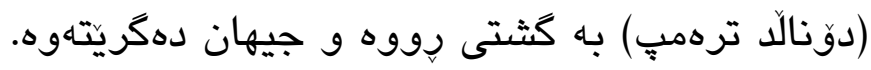

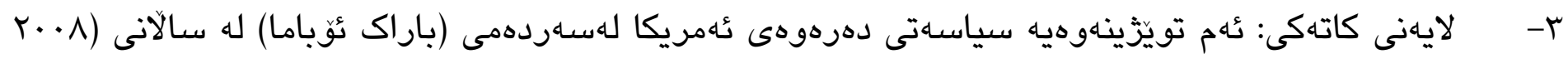

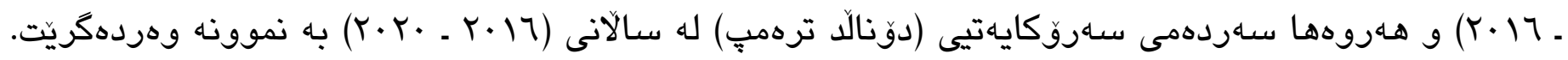

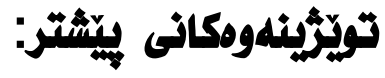

له بوارى نووسينى تويَّينهوهى سياسهتى دهرهوهى ئهمريكادا به زمانى جياواز كَليكَ ليكّولينهوه و تيّز بهرجاو

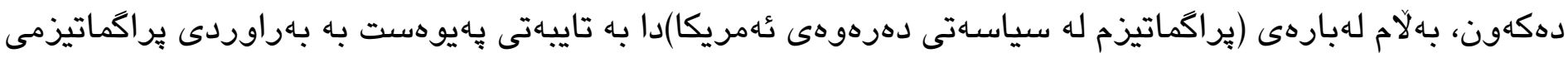

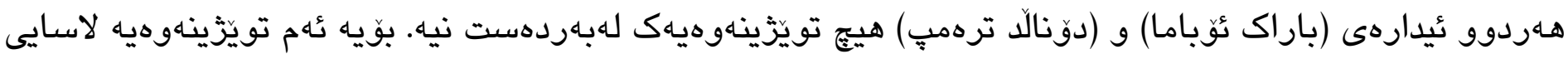

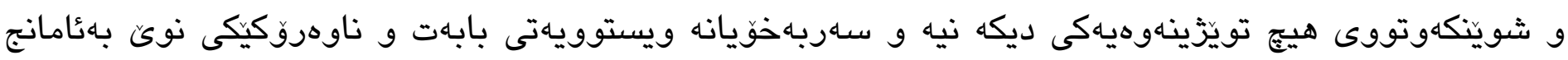

له تويَّينهوانهى لهسهر (سياسهتى دهرهوهى ئهمريكا) له هـريّمى كوردستاندا نووسراون: -السياسه الخارجيه الأمريكيه بعد احداث II سبتمبر |..ب (التغيير و التحديات)، عمر حمد أمين نورالدينى، جامعة

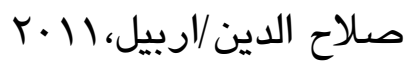

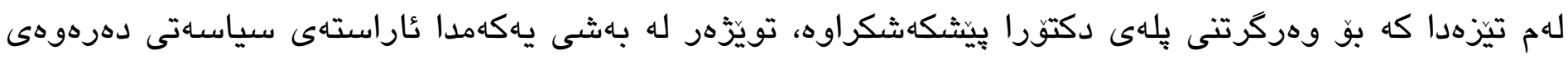

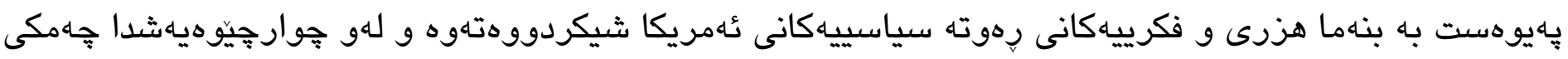

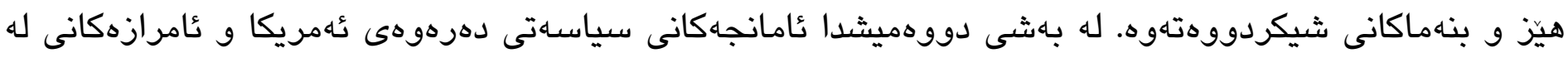

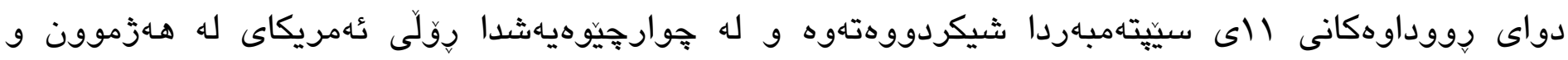

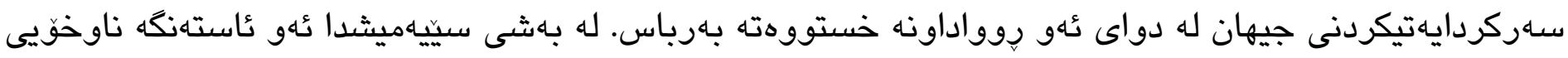

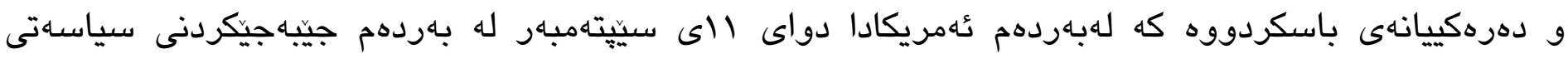

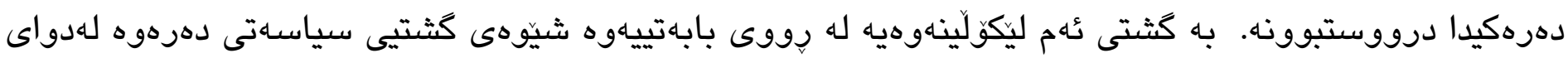

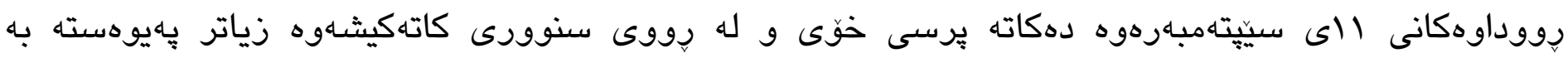

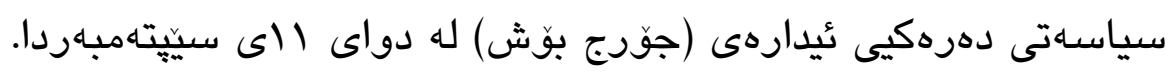


الاستراتجية الولايات المتحدة الأمريكيه تجاه الشرق الأوسط (محاربه الارهاب و دعم التغيير الديمقرطى بين

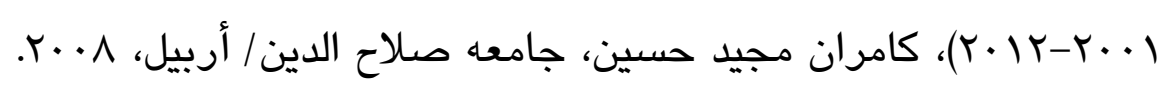

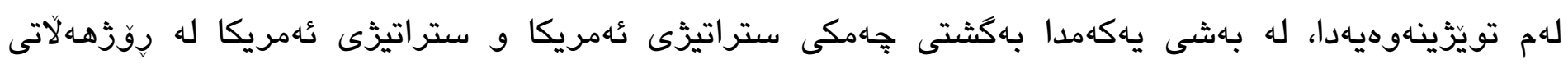

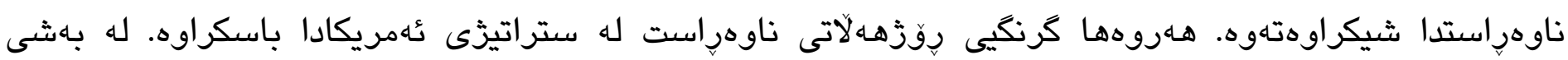

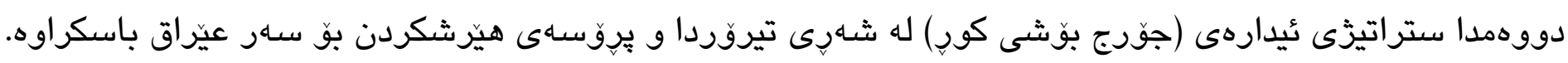

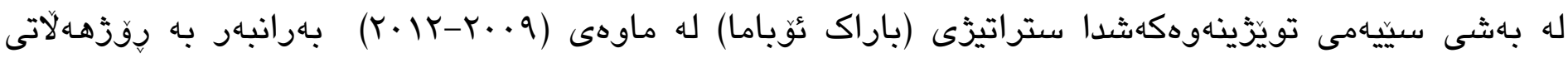
ناوهراست و له روووبهرووبوونهوهى تيروريزمدا باسكراوه. لهم جهوارجيّوهيهدا تاكتيك و ثُامرازى هيزّى زيرهكى

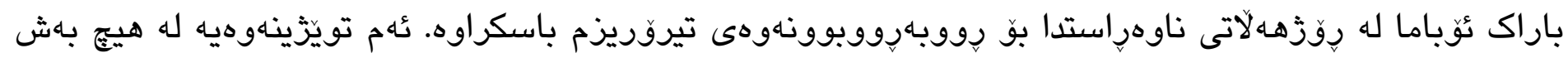
و باسيكيدا باسىى له يِراكماتيزم نهكردوه و له بوارى زهمهنيشدا تهنيا سياسـتى باراك تئياماى له خولى يهكهمى

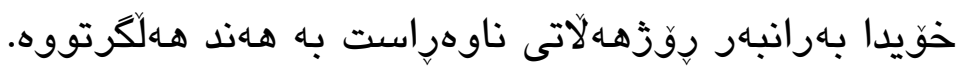

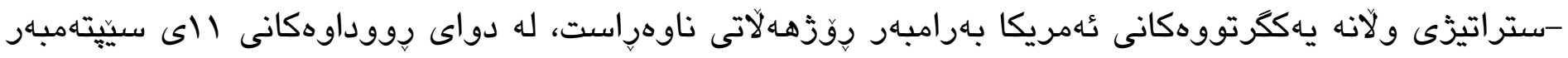

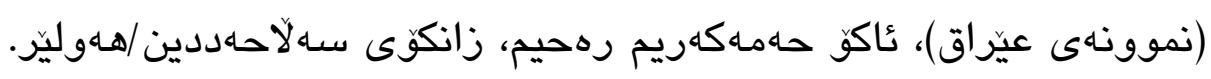

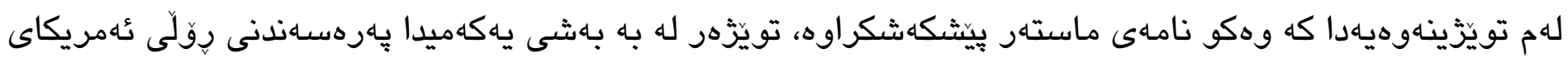
له سياسـتى نيّودودهولهتى و عُامانج و بـرزهوهندييه جوّراوجورهكانى شيكردووهتهوه. له بهشى دووهمدا

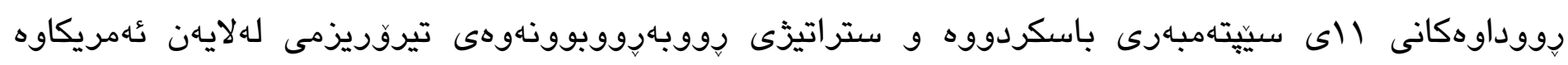

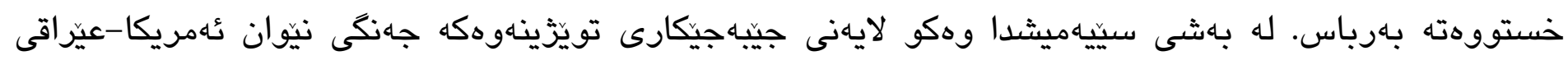

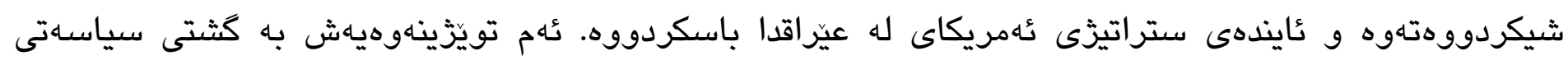

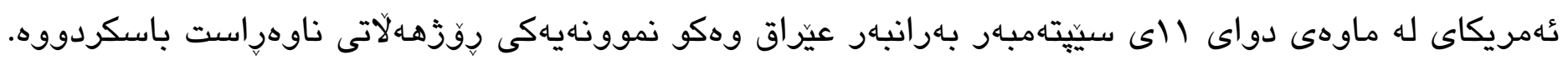

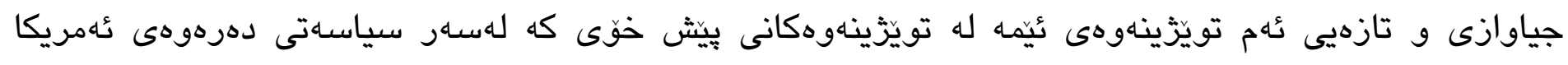

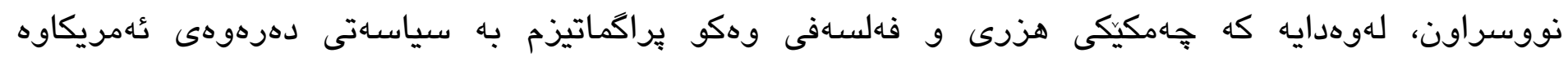
دهبهستيتهوه و للهو روانكُه هزرييهوه شيكردنهوه بو ناراستهى سياسـهتى دهرهوه دهكات. جياوازييهكى ديكه تئوهيه

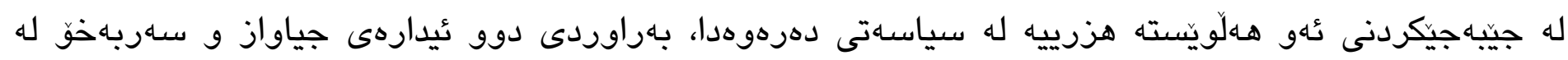
دارشتنى سياسـتى دهرهوهى ئهمريكادا دهكات كه ئيدارهكانى (باراك ئوباما) و (دونالد ترهمب)ه. بـه تايبهتى كه

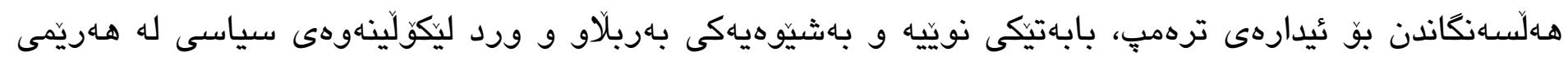
كوردستاندا لهسهر يِيشكه شناهكراوه. 


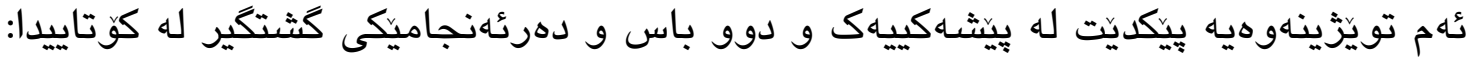
باسى يهكهم: جييهتى و رهكوريشهى بِراكماتيزم دهخاته بهرباس، كه له ميانى جهند تهوهره و لقيكدا جهمك و زاراوه

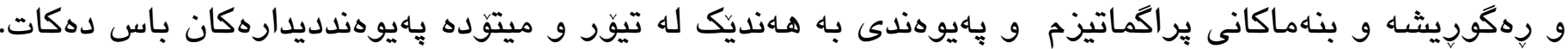
باسى دووهم: كاريكهريى براكماتيزم له سياسهتى دهرهوهى ئهمريكادا شيدهاتهوه، كه له ميانى جهاند تهوهره و لقيكدا بنهما و ئامانجهكانى براكماتيزمى سياسهتى دهرهوهى ئهمريكا و بهراوردى براكماتيزم له سهردهمى هـهردوو ئيدارهى باراك ئزياما و دوّنالد ترهمب وهكو لايهنى بهراوردكارى دهخاته بهرباس.

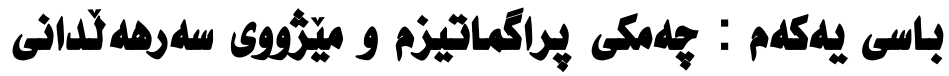

لهم باسهادا له جهند تهوهرهيهكى جيادا، به كثتى زاراوه و جهمكى بِراكماتيزم و بيريارانى سهردكيى عُهو فهلسهاهيه

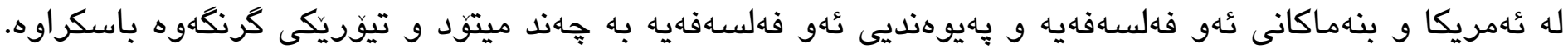

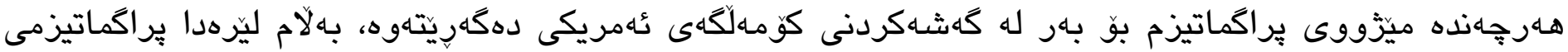
بيريارانى ئهريكى بههاند وهركيراوه.

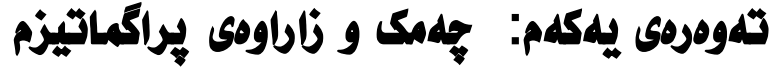

زاراوه و جههمكى بِراكماتيزم ريشهيهكى دورودريّزى ههيه و بنهماكانى دهكهريتهاوه بو سهردهمى كريكى كون. به دريزايى كهشهكردنى رهوتى فهلسهاهش ئهو جههكه لهلايهن بيريار و فهيلهسووفانهوه له ماناى ليَك نزيكدا بهكارهاتوون. تاكو لهلايهن بيريارانى سهدهى نوزدهيهمى ئهمريكاوه مانا و تايبهتمهندى و شيّوهى نويّى يِيّدرا.

\section{ثقى يلdكdم: زاراومى هراكماتيزم}

زاراوهى (يراكماتيزم ـ Pragmatism) كه له زمانى عهرهبيدا به (براغماتيه ـ الذرائعية) ناودهبريّت، له وشهاى ديّرينى يونانيى (Pragma) هاتووه و دواتريش هـريهك له وشهكانى ( Pragmata، Pragmatos)، له

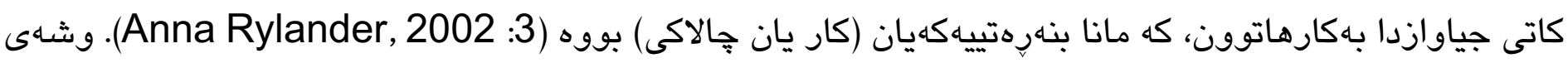

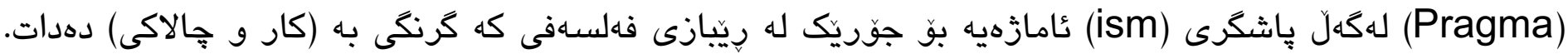
له سهدهى پֶانزدهى زاييندا، هـمان وشه له زمانى فهرهنسيدا به (Pragmatique) كَّكراوه. له زمانى لاتينيدا Susan hack, ) وهكو ماناى كار و دهرئهنجامى كاريك و جييّهيكردنى شتيك بهكارهاتووه (Pragmatism) 


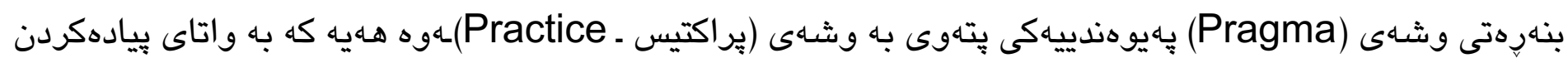

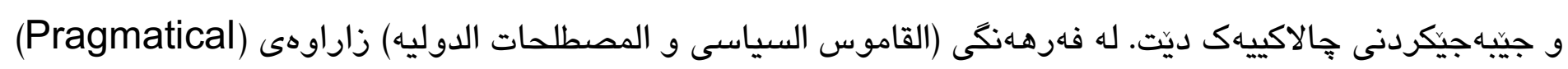

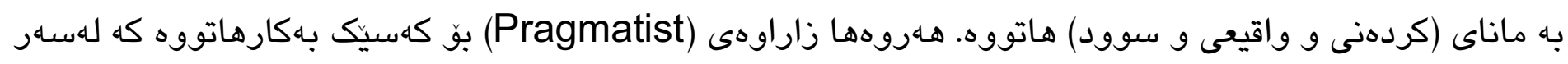

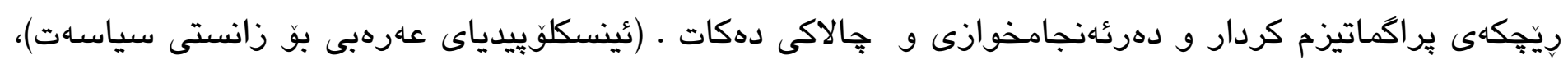

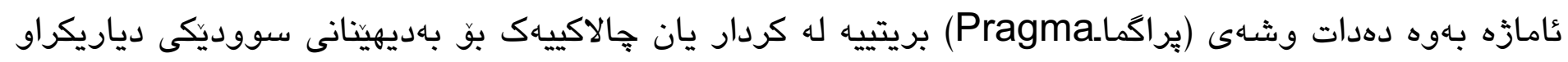

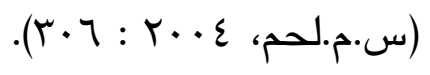

كهوايه به كثتى بِراكماتيزم و رِيشهكانى، به مـهبهـت و واتاى كردار و جالاكى و بيادهكردن بهكارهاتوون و هـهر

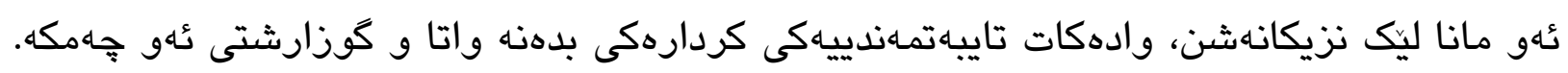

\section{لقى دووهم: بيّناسهى هيراكماتيزم}

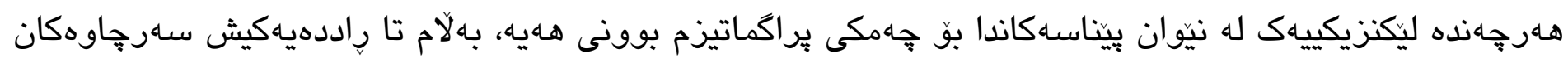

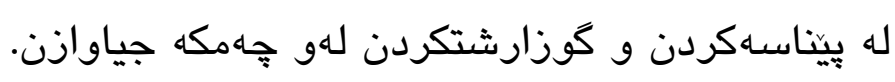

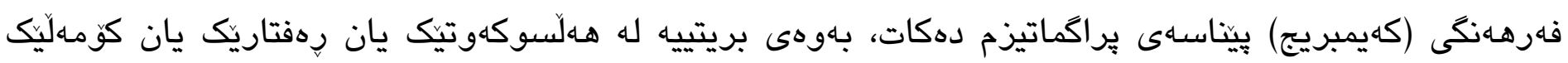

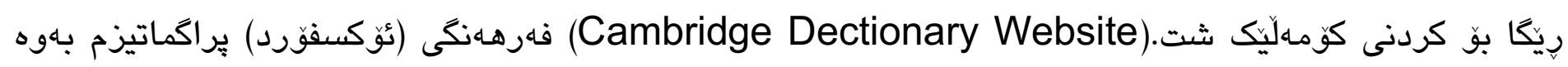

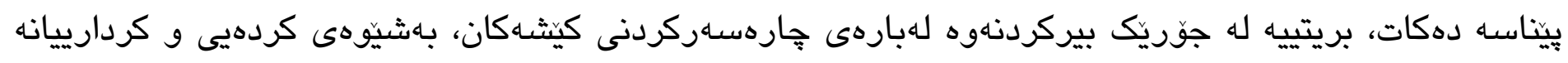

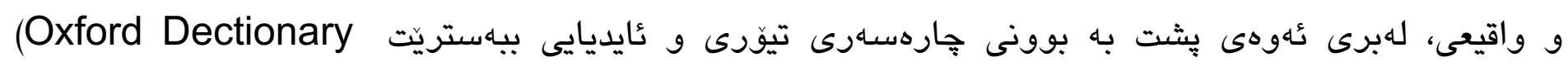
.website)

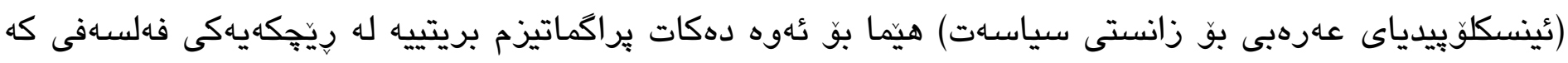

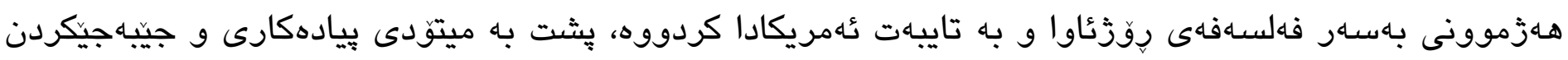

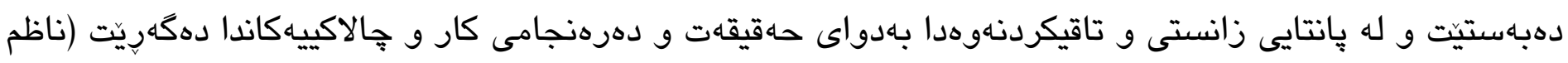

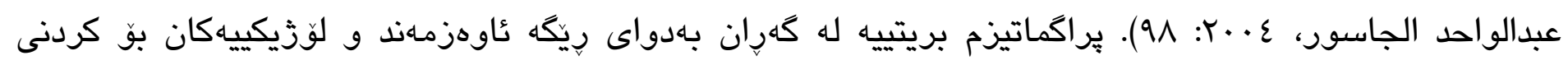

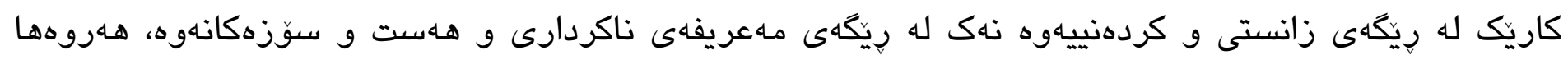

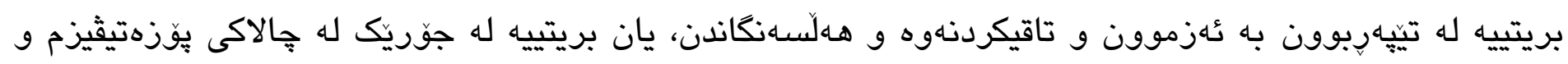

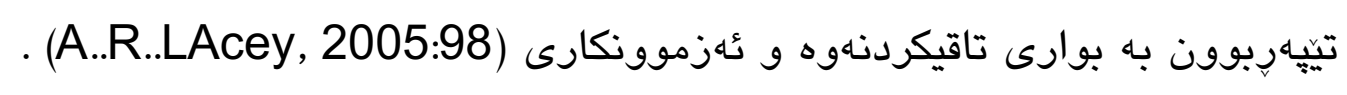

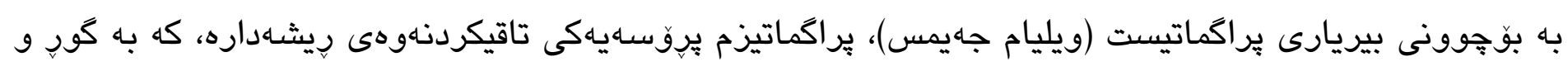

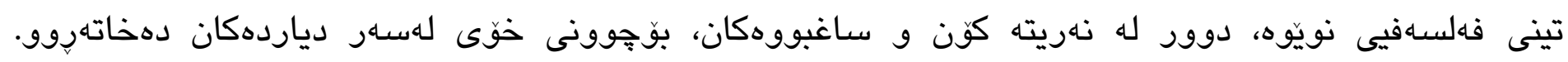

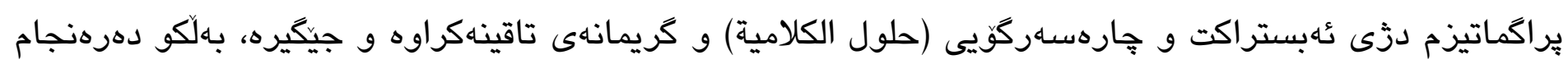

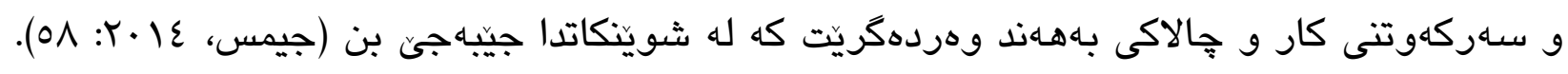




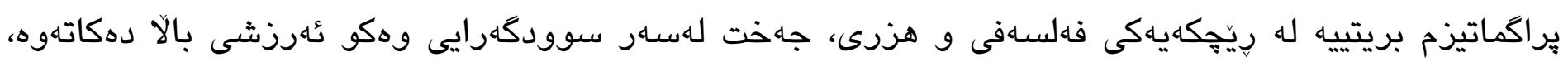
وايدهبينيت سوودوهركرتن و تئزموونكارى بهايهكى يِيوهرئاميّزى هـيه بو كهيشتن به راستى و جاكه و

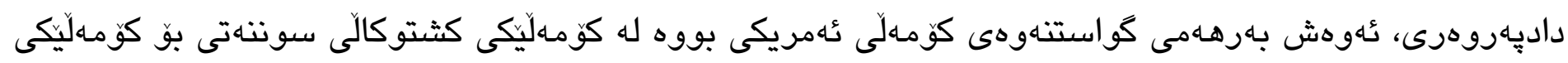

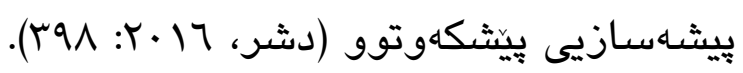

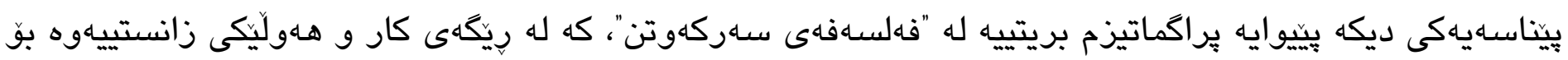
درووستكردنى كاريكَرى بـهديديت، بوّيه تُامانجى سـهرهتا و كوتايى لهو فهلسهاهيهدا بريتييه له بهديهينانى

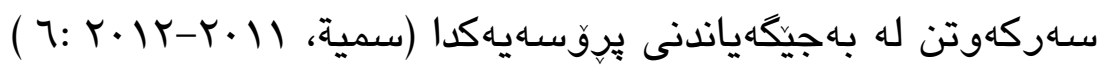

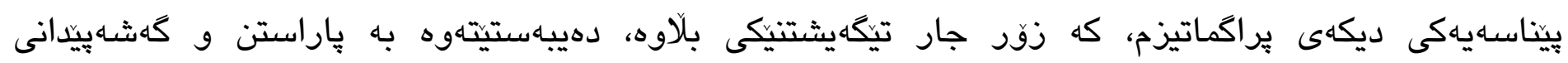
بهارزهوهنديخوازييهوه، واى بو دهيّت كه يراكماتيزم يشتكردنه له بهها و نورم و بنهما رهوشتييهكانه و تهنيا كرنكى

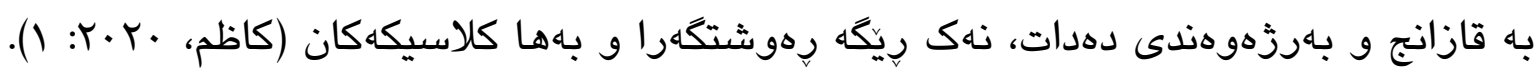

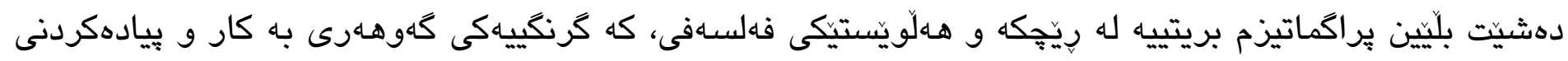

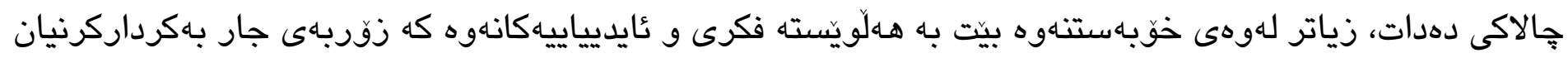

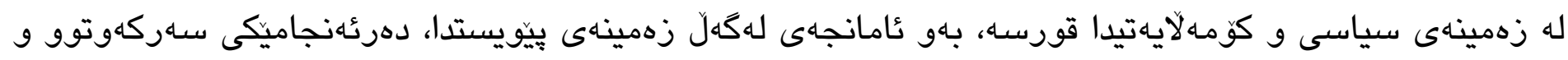
واقيعييانه له كردار و جهالاكييهكه بكهويتهوه و بـه سوود و قازانج بشكيتهوه، هـهر تُهوه بـه بنهماى حهقيقهتبوون و راستى دادهنيت كه دهتوانريّت به روونى دهرئهنجامى جالاكييهكه بيينريّت و سوودى ليّ بكهويتهوه.

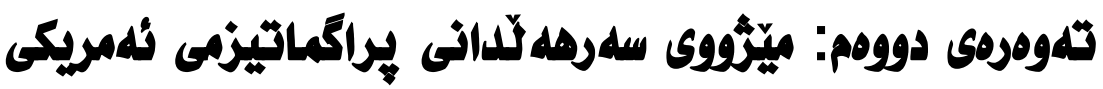

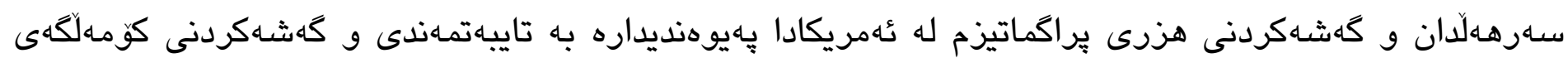

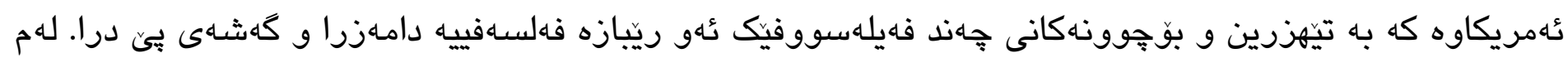

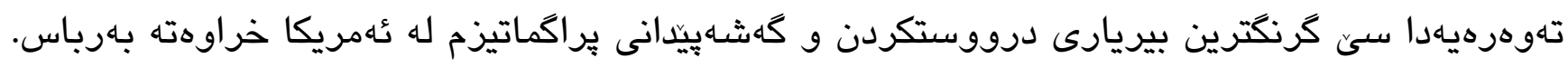

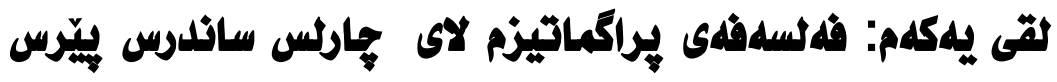

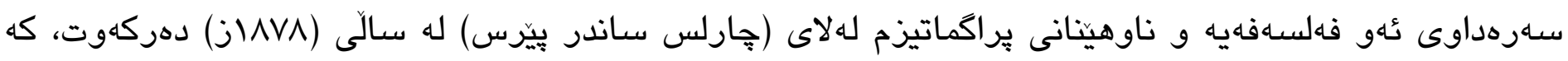

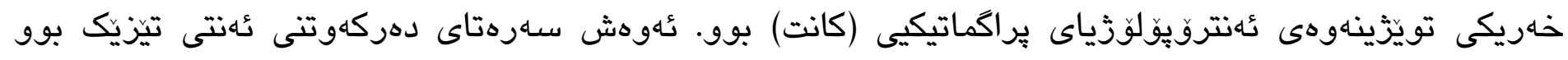

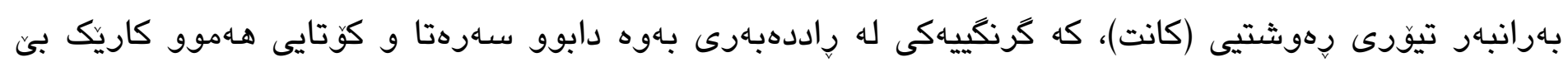

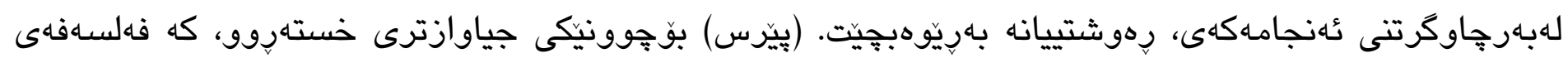

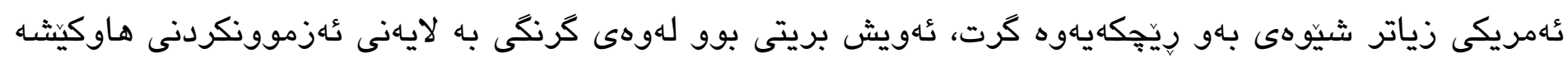
عهةقلييهكان و بهكردهنيكردن بلدريّت (Jaime Nubiola,1996:10).

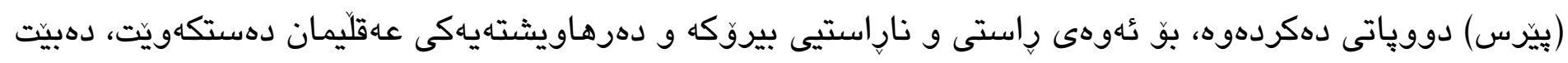

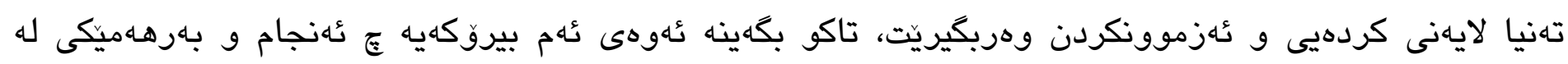

DOI:https://doi.org/10.26750/Vol(8).No(3).Paper27 http://journal.uor.edu.krd/index.php/JUR Vol.8. No.3,September.2021 
واقيعدا هـيه، وه يِيّويسته بيروكهكان هـر تهنيا له فوّرمى كوزارشتكردندا نهبن، بهلكّو رِوون و كردهنى بن.

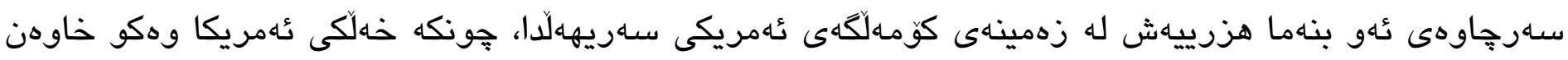

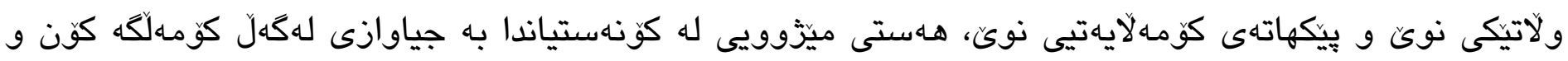

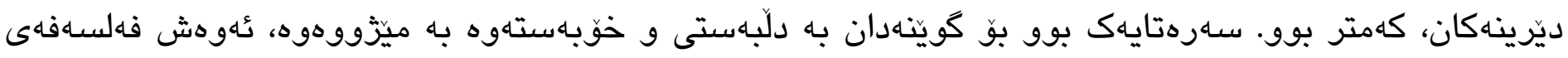

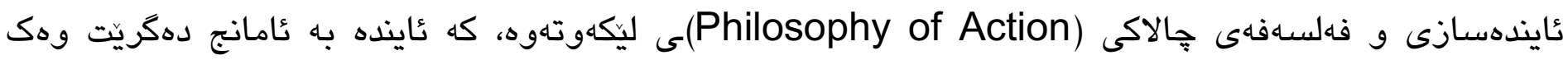

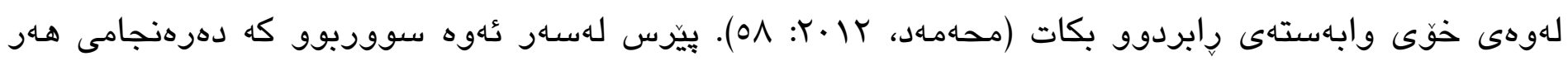

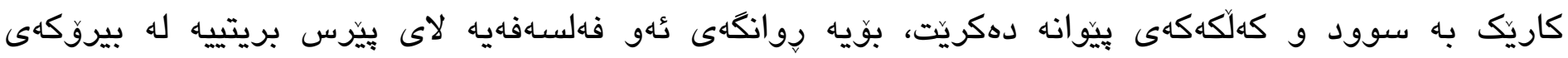

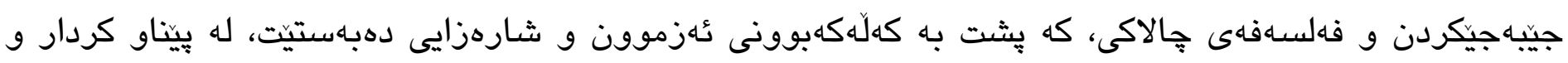

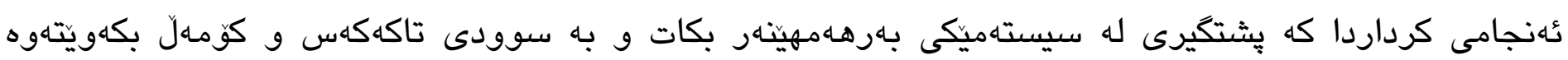

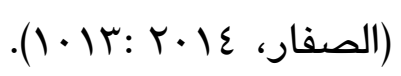

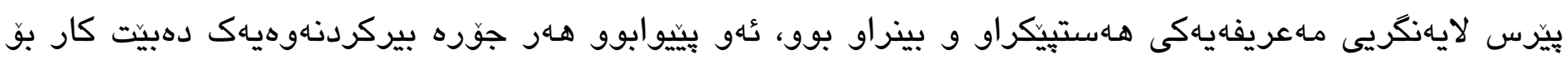

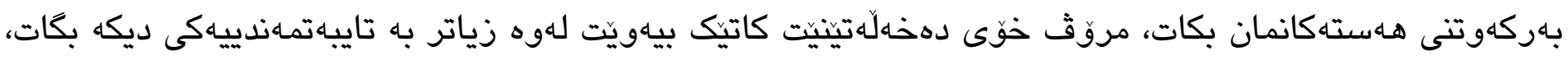

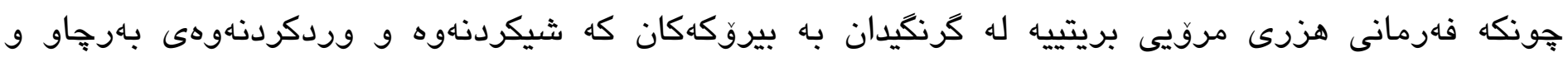

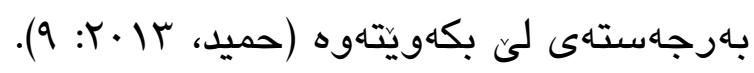

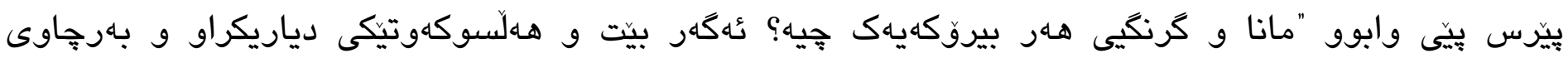

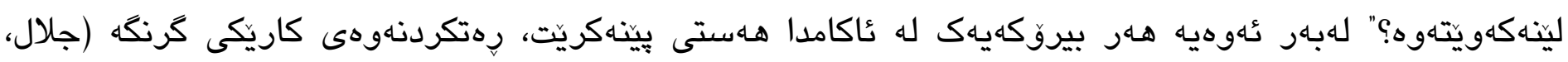

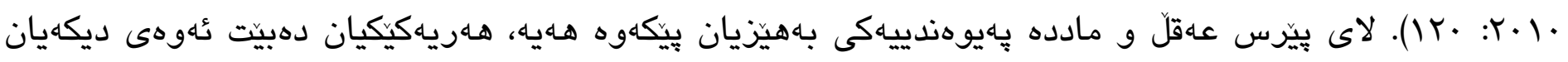

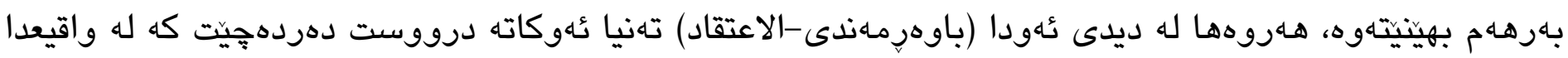

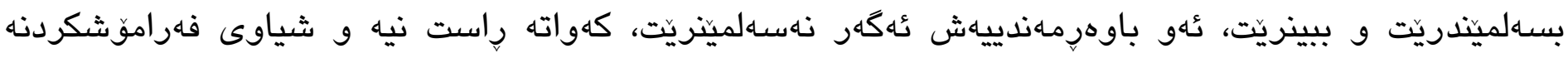

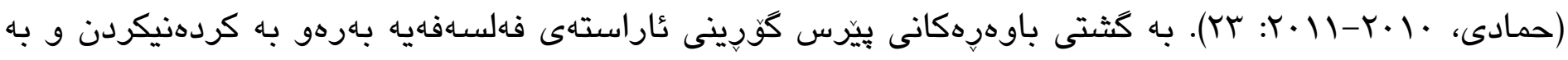

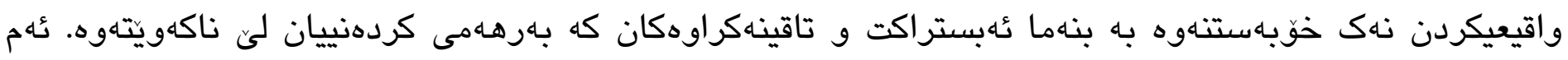

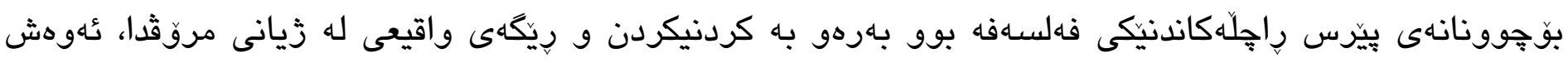

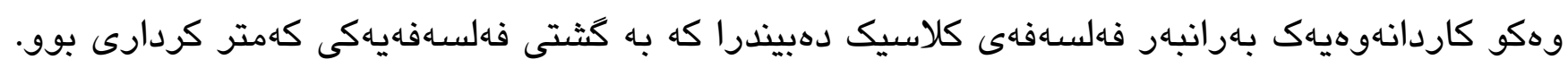

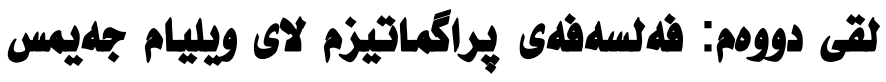

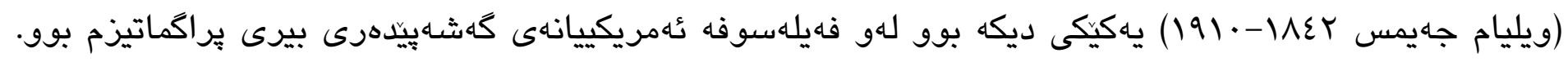

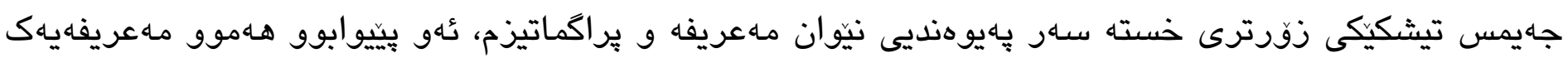

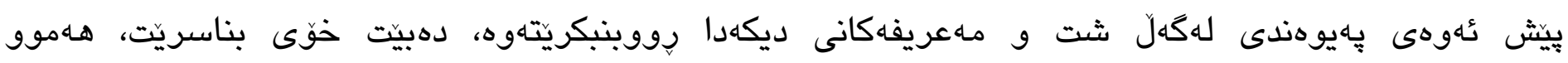


مـهريفهيهكيش قولتره لدوهى به رِووكهش دهردهكهويّت، لهو زهمينهيهشدا هـموو رِاستييهك هـلومهارجى خوّى

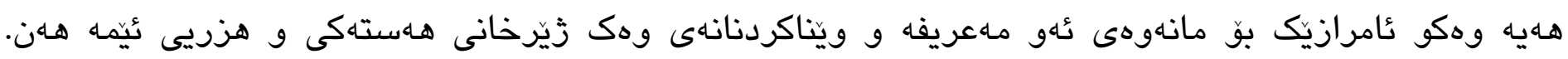

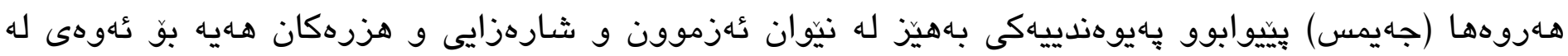

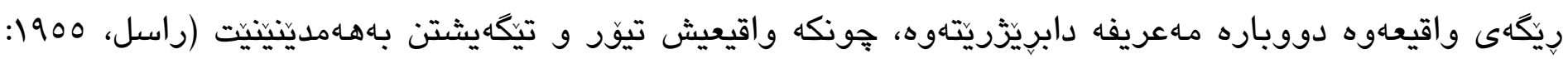

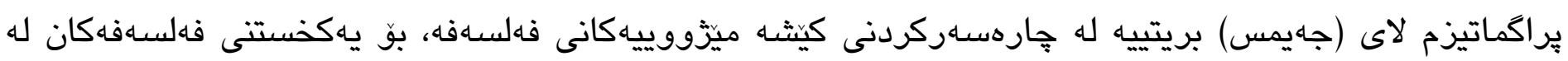

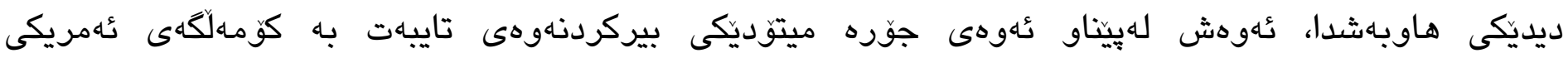

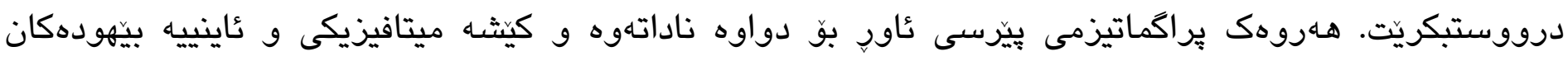

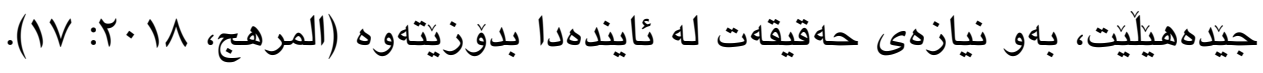

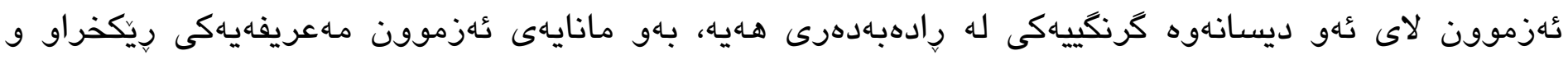

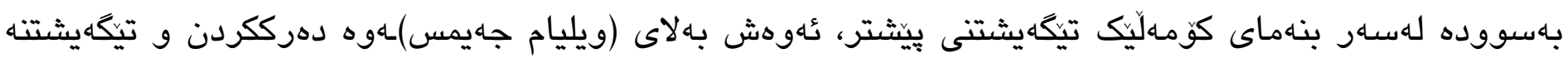

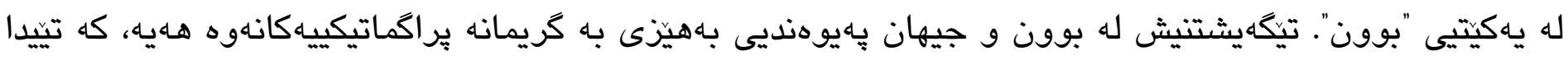

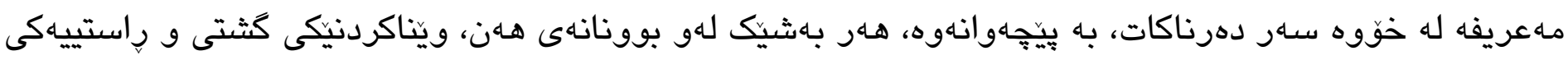

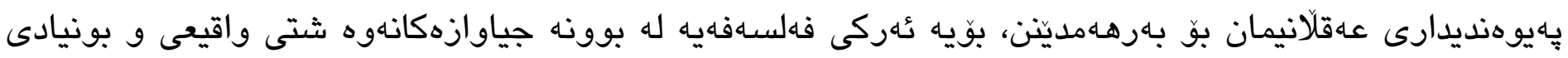

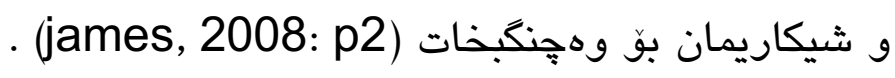

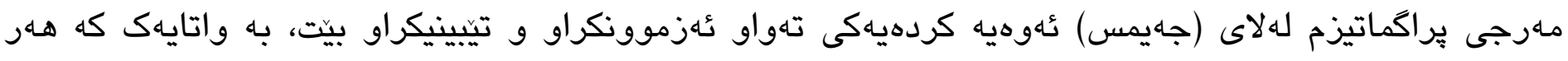

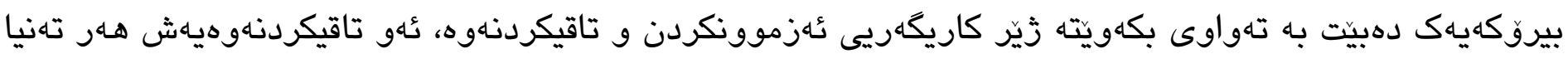

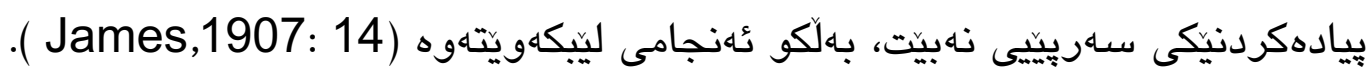

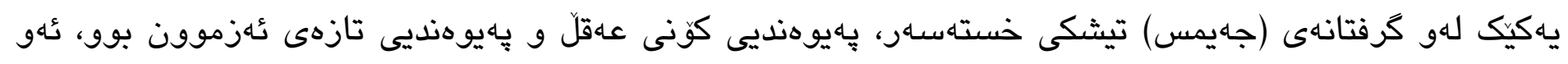

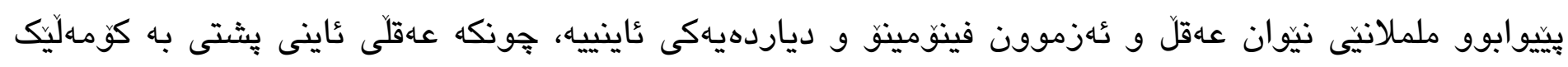

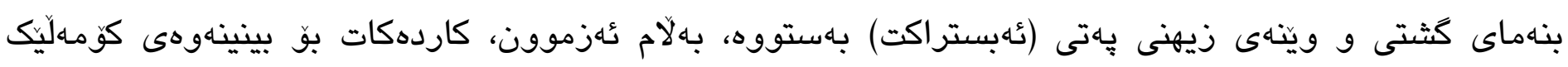

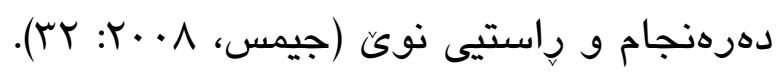

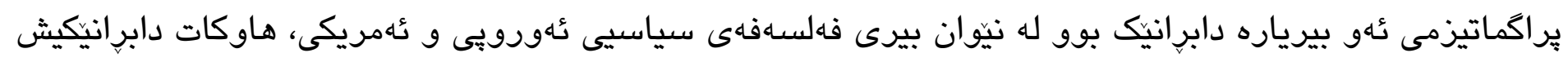

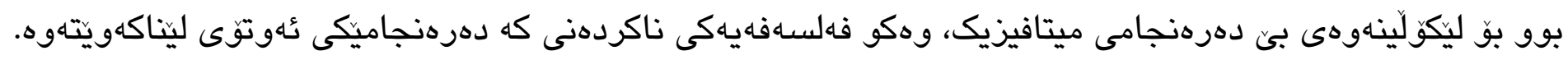

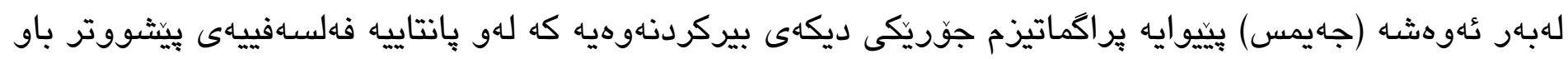

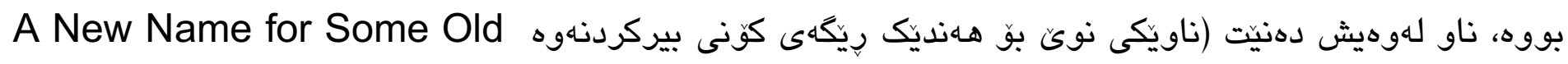
(Ways of Thinking)

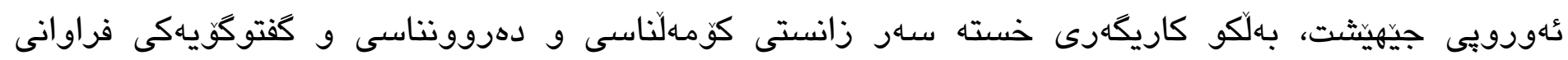


درووستكرد (Jack Barbalet, 2004: 337 (J). كَه بيّرس بيّشنيازكارى براكماتيزم بووبيت، ويليام جهيمس زياتر

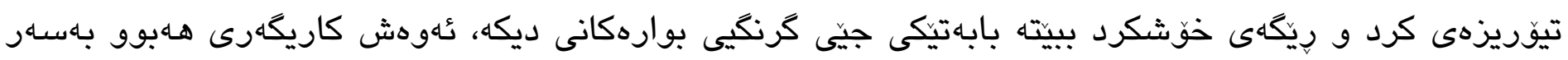

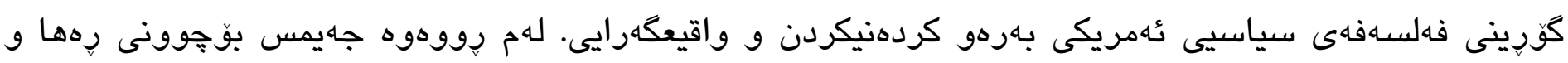

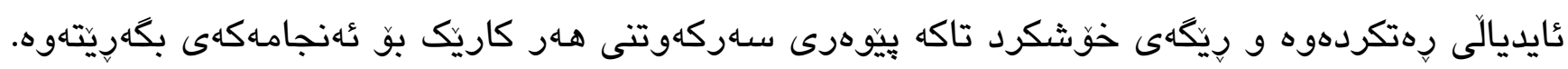

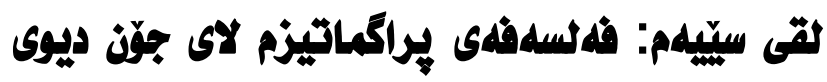

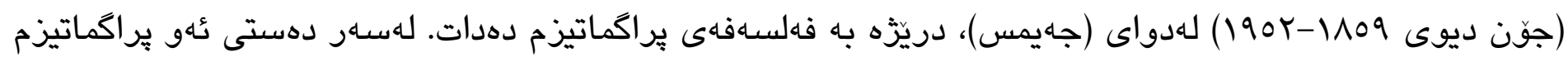

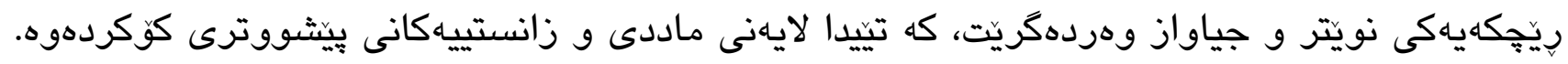

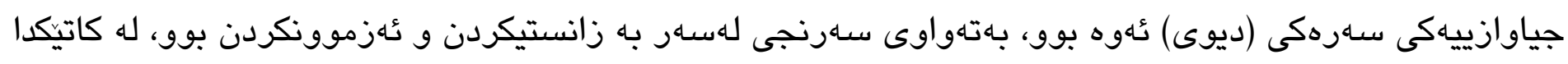

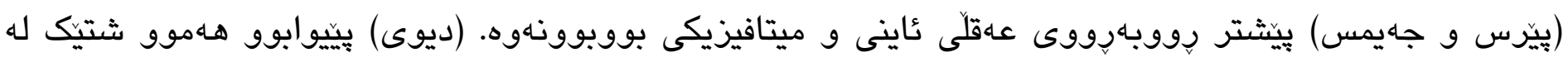

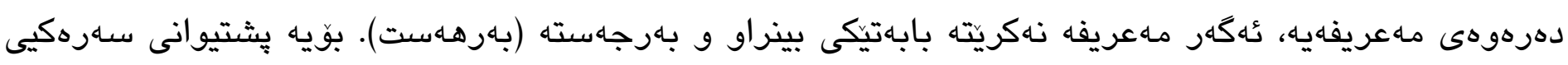

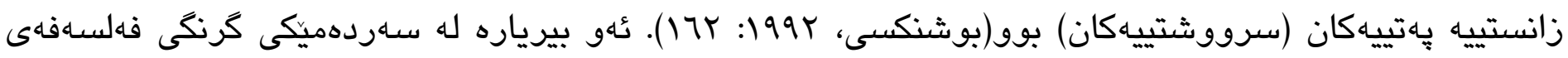

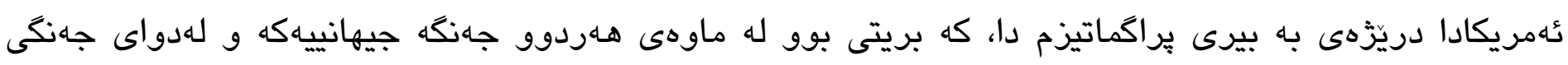

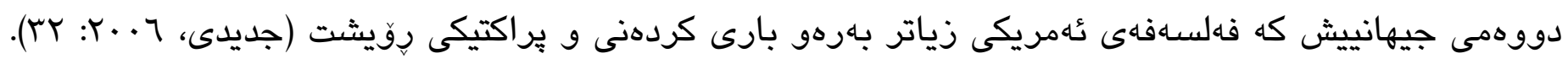

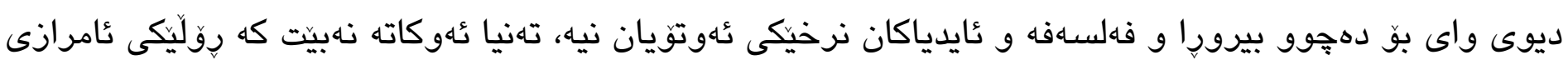

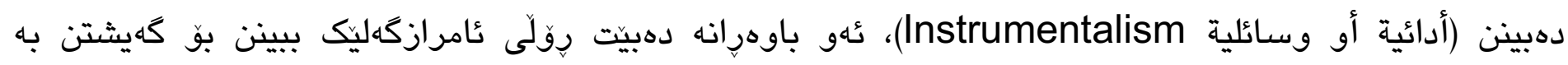

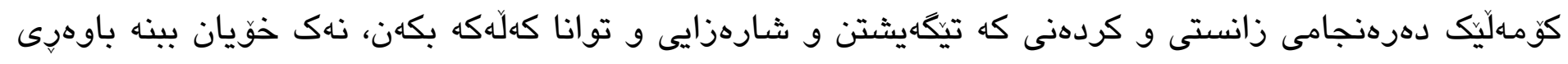

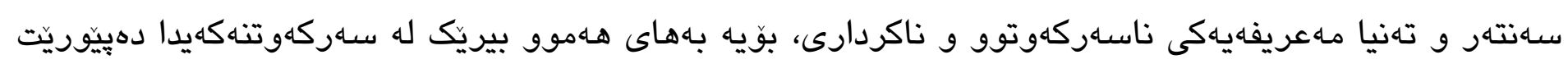

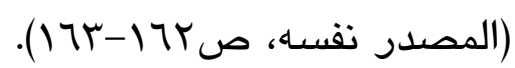

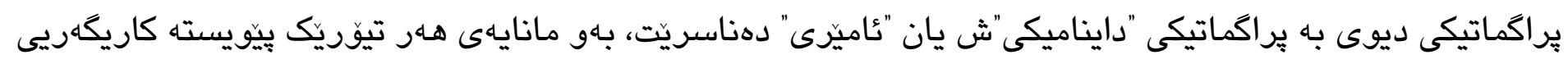

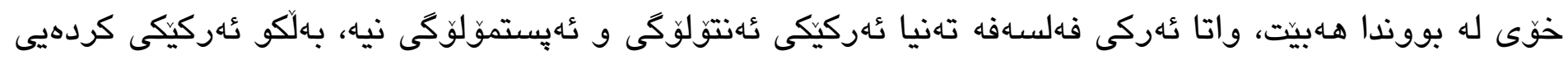

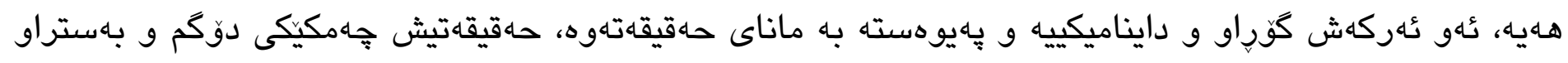

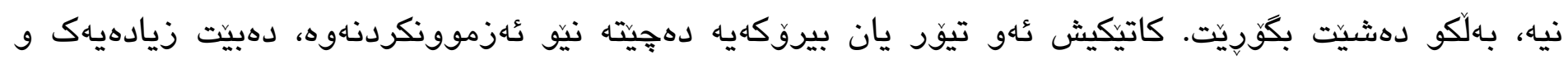

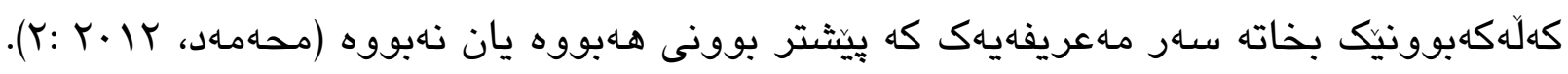

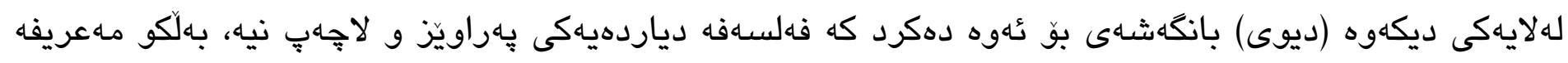

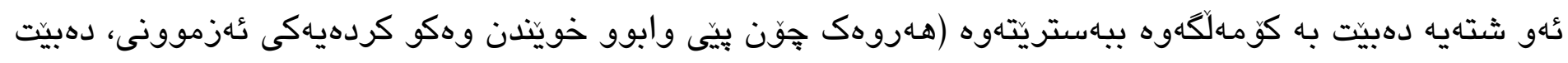

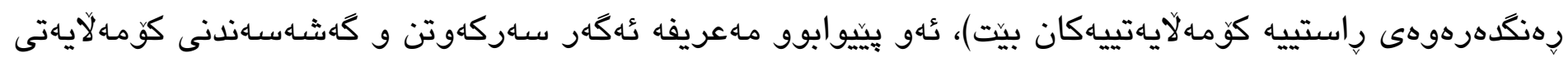

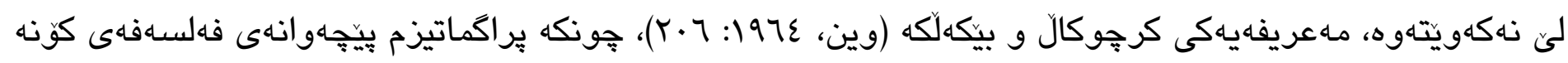




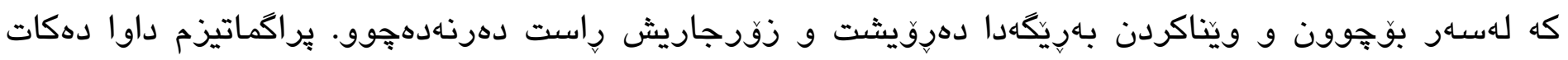

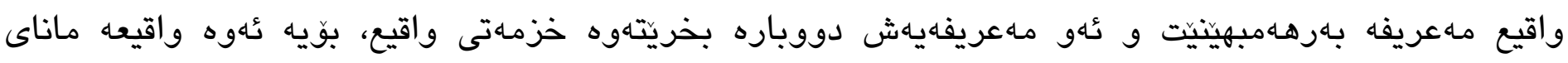

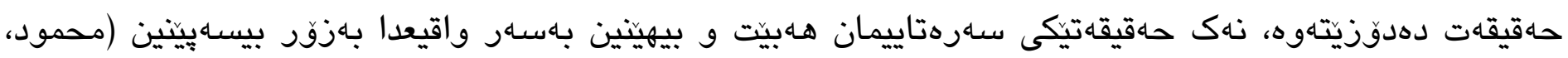
. (YTY: 1994

فهلسفهكى (ديوى) له كُرهيانى تاقيكردنهوه و كُهزمووندا كاريكهرييهكى كهورهى خسته سـر فهلسهفهى سياسى

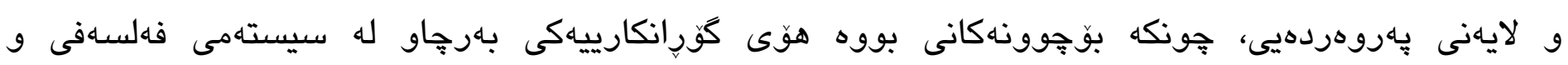

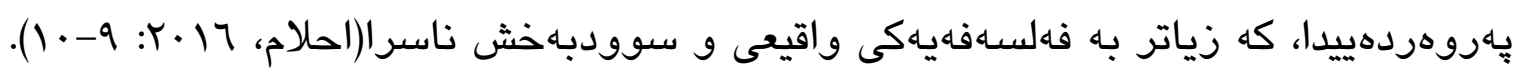

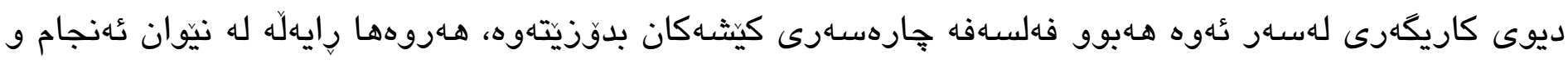
ئهزموون درووستبكات و له قوَناغى دواتريشدا جارهسهرى نيّوان رهكَّز و رههـهده جياوهزهكانى دياردهكان دهستنيشانبكات. نابيت ئهوهش لهبير بكهين كه فهلسهفه تُزموونكردنهكهى (ديوى) فهلسهفهيهكى تاكگهراييانه و

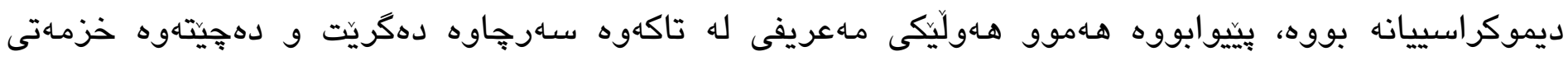
تاكهكه سيش.

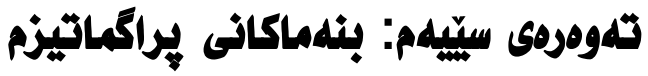

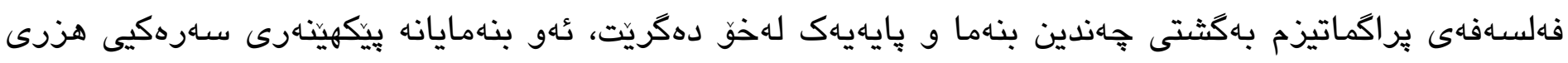

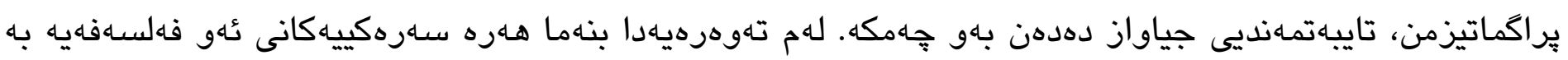
كُشتى زميَّدراون:

\section{ثقى يلهكهم: بنdماى نازادى}

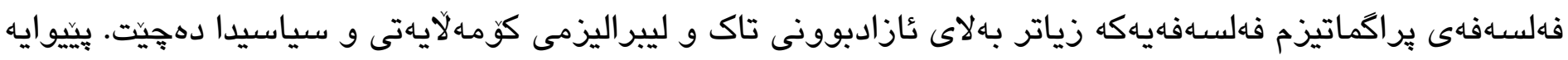

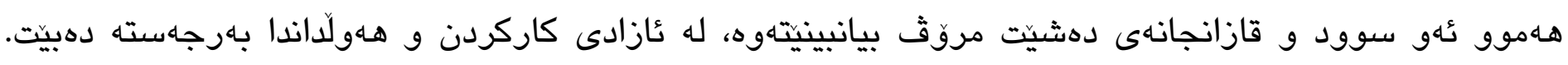

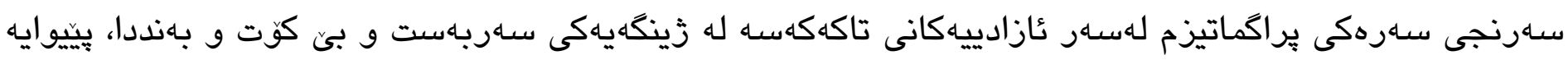

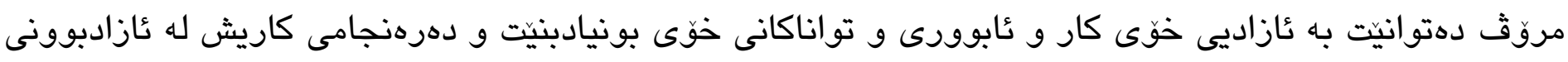

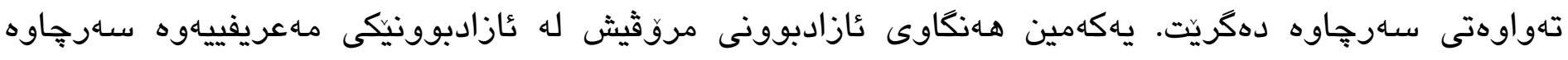
دهكريت كه به ديويَكى ديكهيدا خَرِزكَاركردنه لـه باوهره باوهكانى ئاين و ميتافيزيك و بوّهوونه نادوونيياييهكان

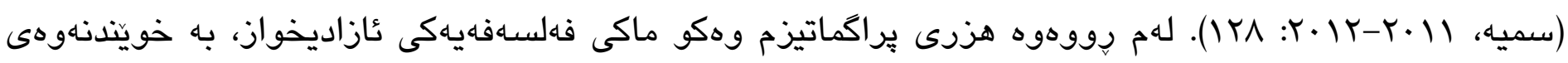

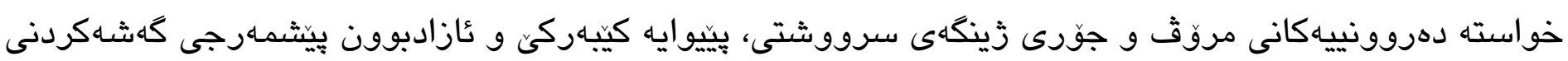

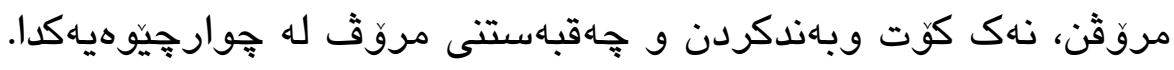


براكماتيزم به فهلسهاهیى زانستى ههزمار دهكريت، جونكه ئاراستهيهكه لهسهار بنهماى تاقيكردناوهى زانستى (وليم

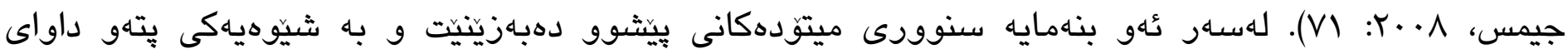

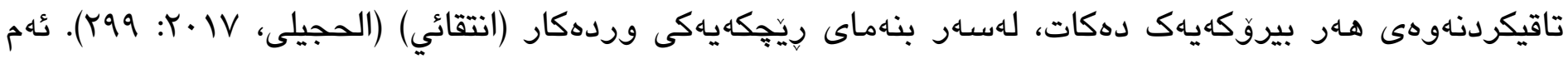

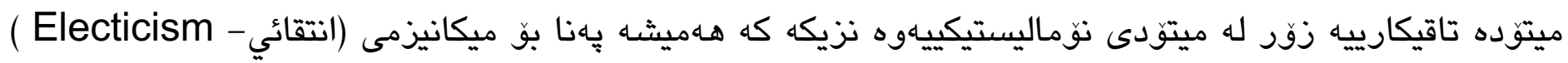

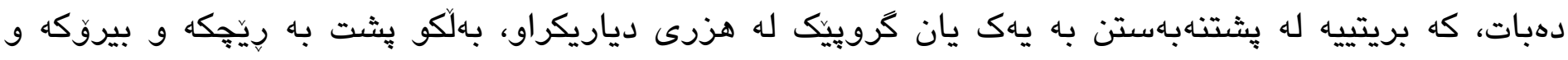

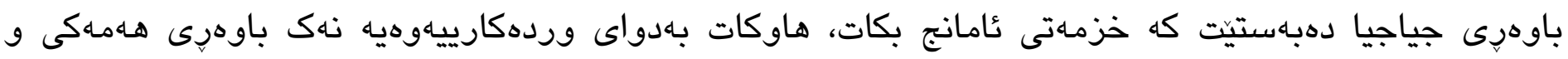

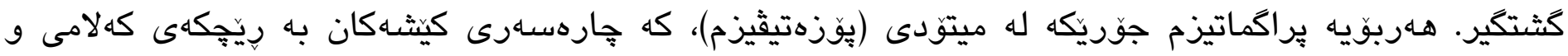

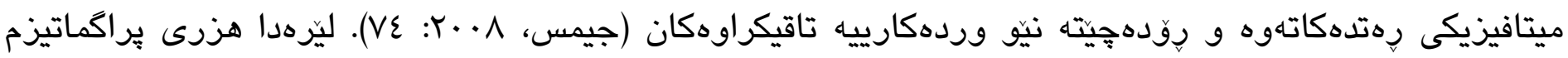

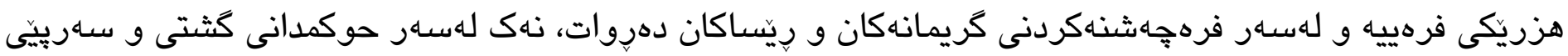

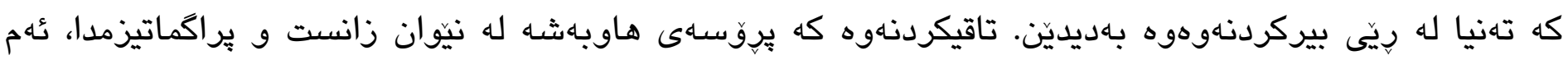

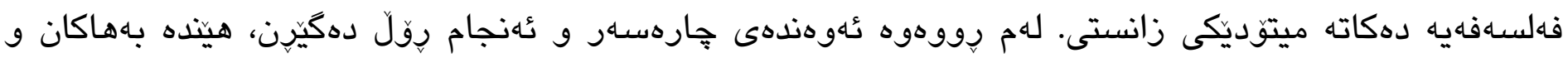
بناهماكانى ديكه بهههاند وهرناكيرين.

\section{A break from the past لقى سييّه: دابران له بإبردود}

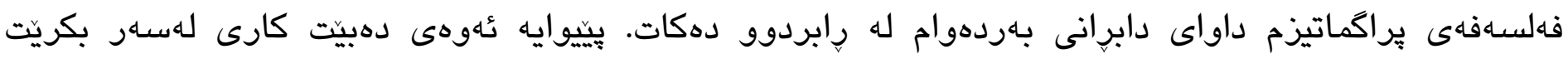

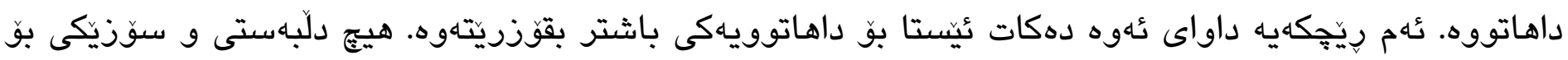

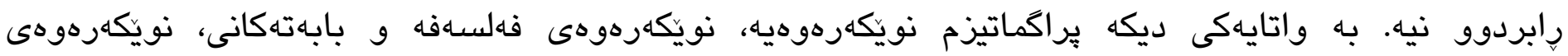

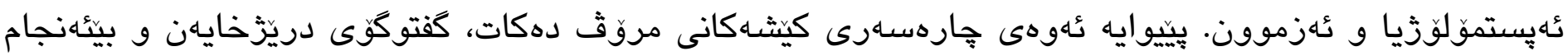

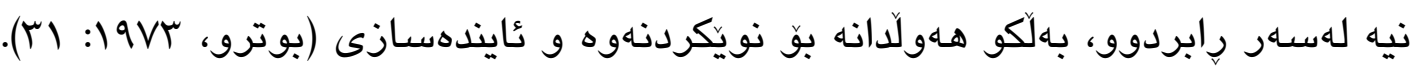

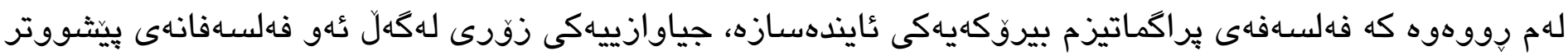

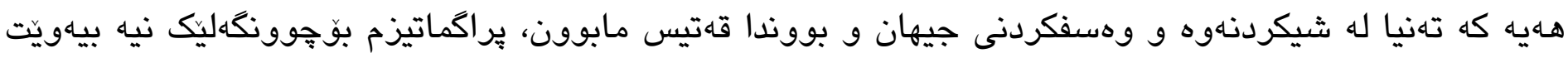

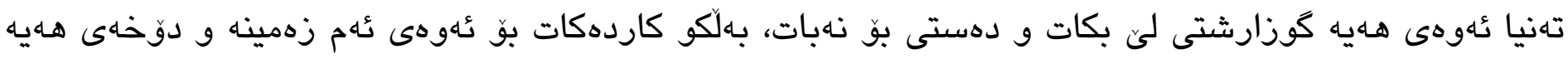

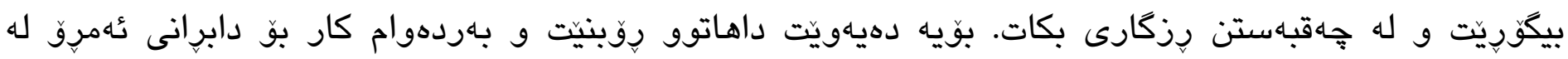

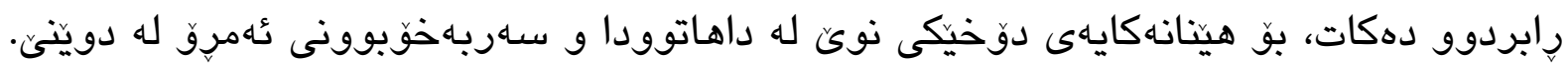




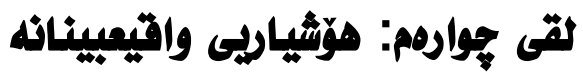

يه كيكى ديكهيه له پِايهكانى بِراكماتيزم. بِراكماتيزم داواكارى ئهوهيه له مشتومر و كَتارى فهلسهفى و بيرياريدا، هوّشيارييهكى ورد بوونى ههبيّ. يُيّويستيشه راستى و درووستى بيروكهكان يهكلابووينهوه. ئهو هوّشيارييه بهنده

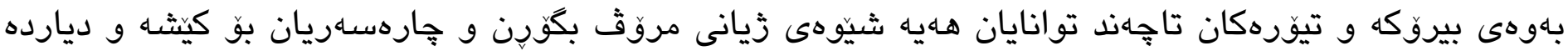

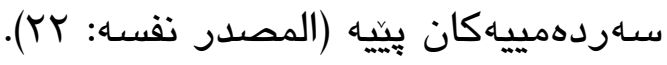

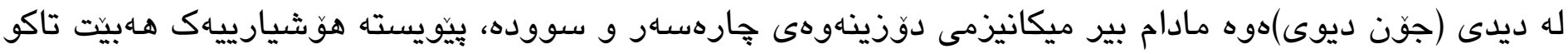

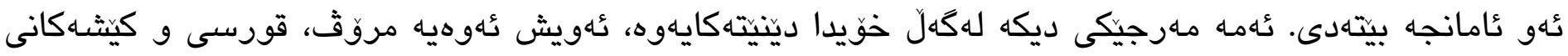

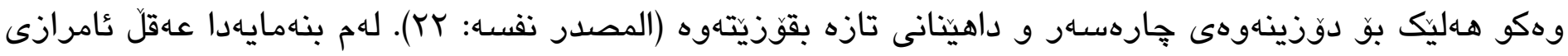
تيكَهيشته له جيهان، كاريش بو كوّرينى تيور و فهلسهاهكانى دهكات، بو بهديهينانى هوّشمهندييهكى باشتر لهبارهى زيانهوه. ئهو هوَشمهندييهش تهنيا تيوريزهكردن نيه، زياتر لهوه هوَشمهندييهكى واقيعييه و واقيع دهخاته زيّر دهستى

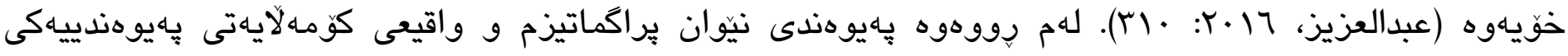

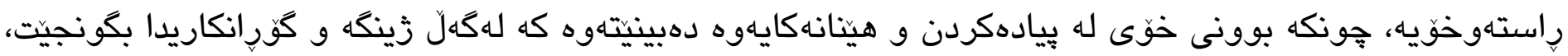

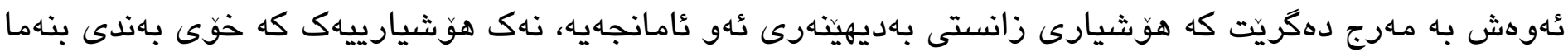
نهُوَرِكان بكات.

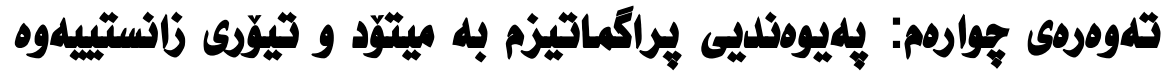
براكماتيزم يهايوهندى جوّراوجوّىى به ميتود و تيورى زانستى و فهلسهفييهوه ههايه. لهم تهوهرهيهدا كَرنكترين

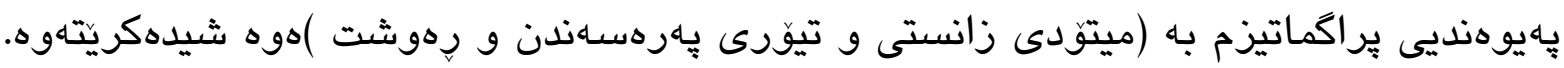

\section{لقى يلكلهم: هراكماتيزم لله ميتوّدى زاتستيلا}

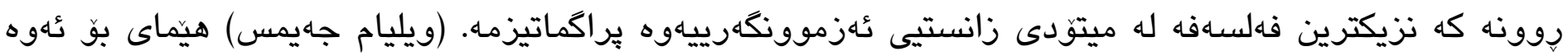
كردووه" به هوَى براكماتيزمهوه، هـريهك له لوك و هيوم و باركلى، بهشدارييهكى كارايان له تيكّهيشتن له راستى

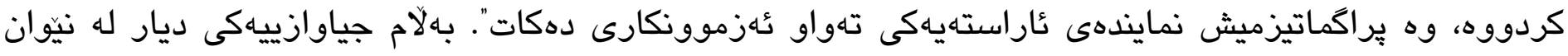

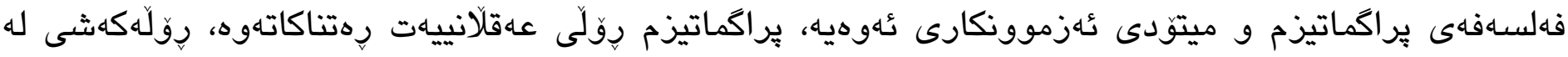

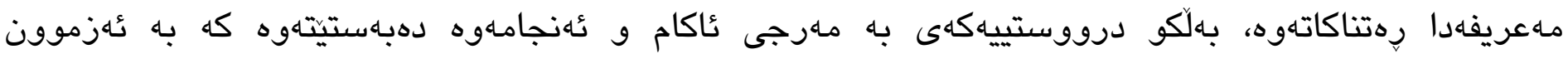

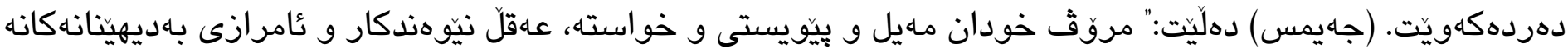

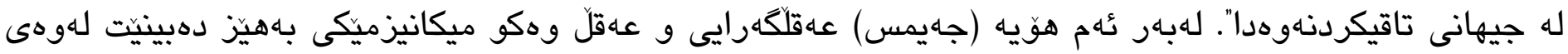

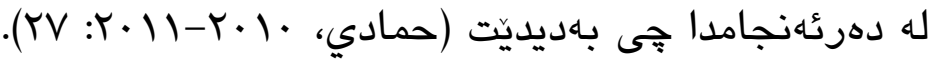




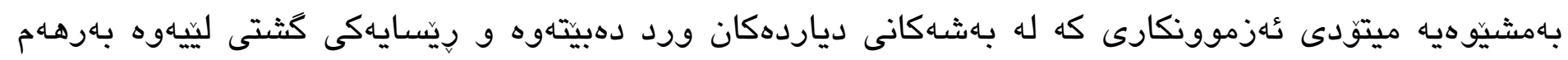

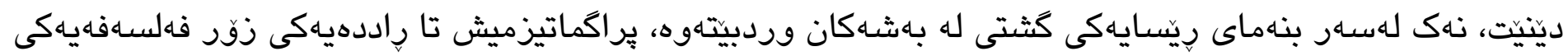
زانستى و ئهزموونييه و لهسهر بنهمایى هـماهـنكيى عهقل و دهرهنجام، پِهندى ئهزموون و تاقيكردنهوه دهدات. دياره فهلسهفهى يراكماتيزم به هوَى كاريكهرييه يِيشكهوتووهكانى زانست له سههدى نوزدهيهم بهرهو سـهر،

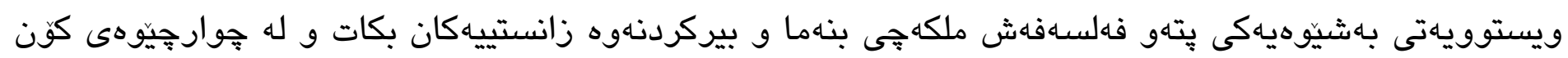
رزخكارينكات.

\section{لقى دووهم: هلهيوهذليى تيوّرى داروينيزم به فهلسهفهى هراكماتيزمهوه}

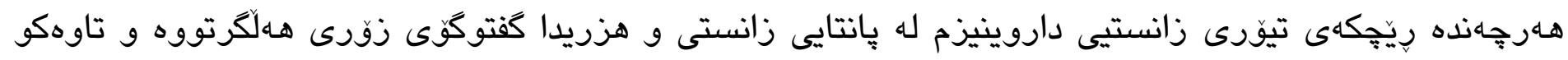

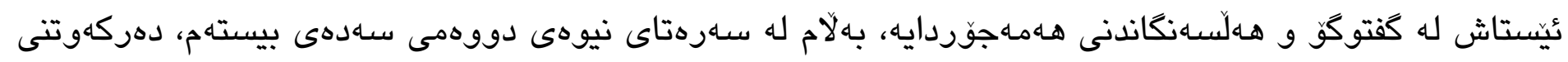

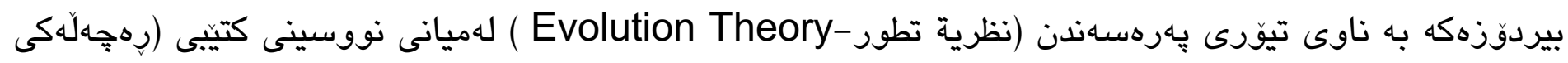
جوَرهكان زانستييهكان بوّ "بوون" درووستكرد. لهبهر تُهوهى هـزَاندنيكى زانستى بوو لهمهر تيكَهيشتنه باوهكانى يِيشوو كه له ديدكاى تاين و فهلسهاهذوه دهيانروانييه بوونى زيندهوهران و مروث.

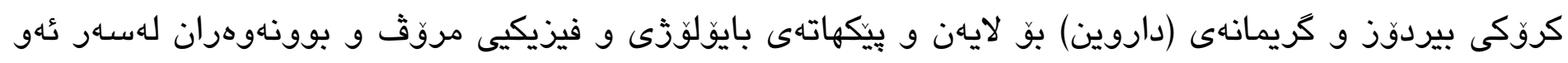

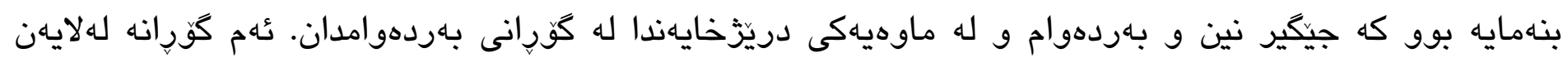

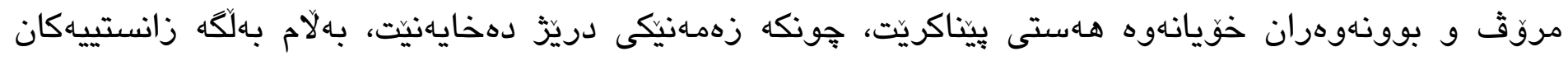

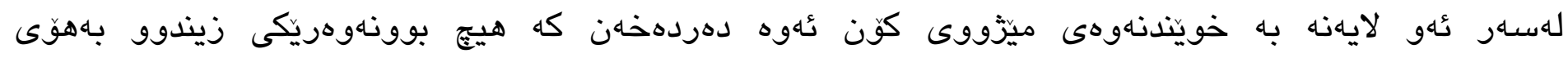

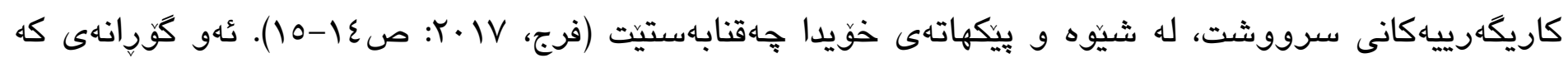

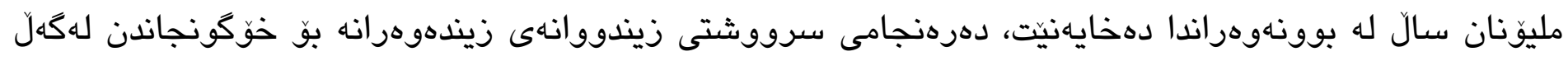

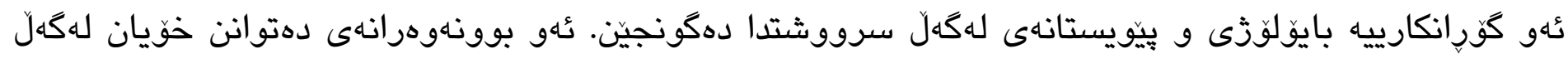
بارودوخى نويَى سرووشتدا بكُنجينَن و خَّيان له هيَزى بوونهوهرانى ديكه بياريَزن دهمينتهوه و ئهوانى ديكه كه ناتوانن خويان لهكَل سرووشتدا بكونجينن له دريّزّماوها كهدهبنهوه و قر دهبن، تُهمهيه كه داروين ناوى

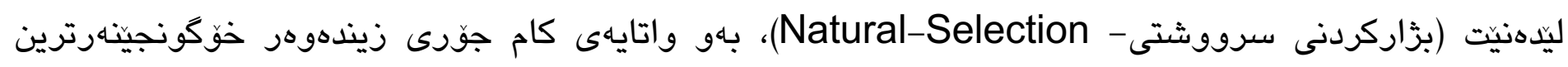

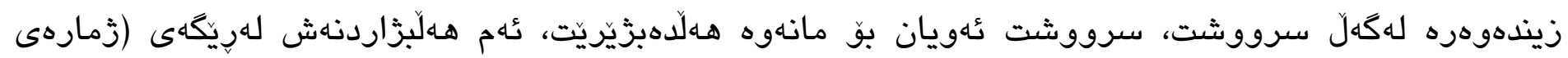

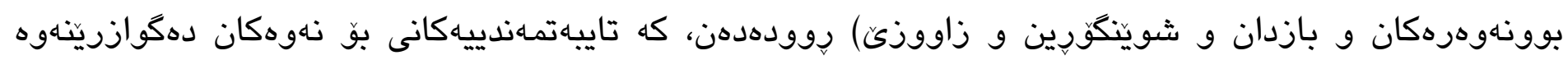

(المصدر نفسـ: (10). 


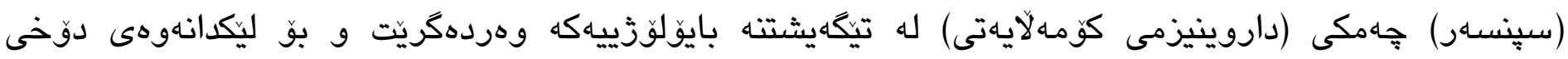

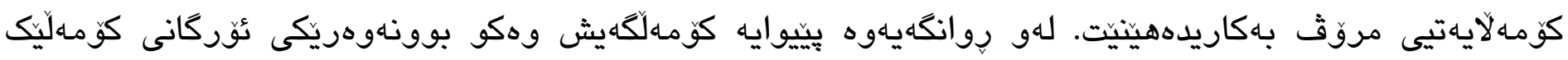

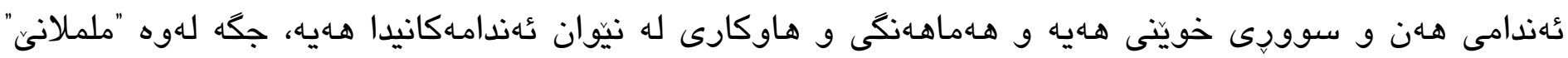

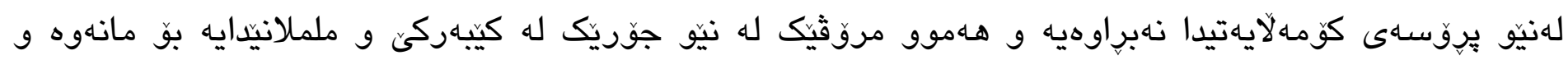

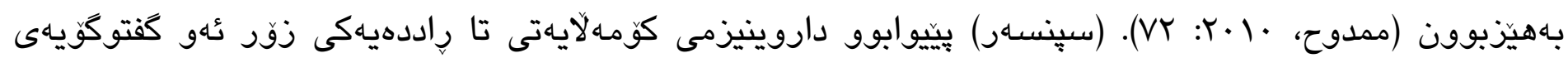

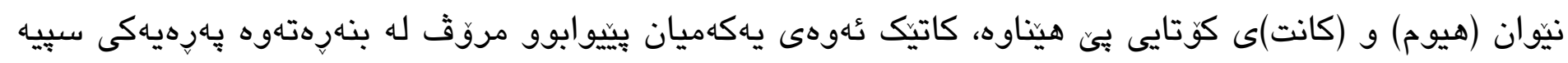

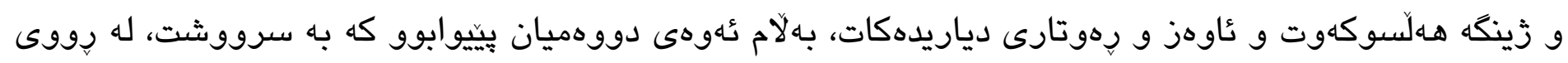

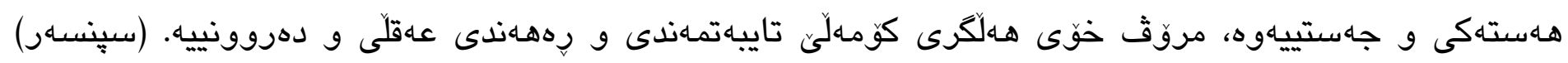

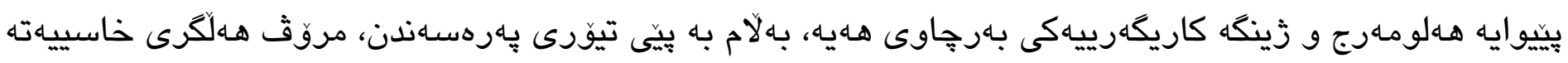
سرووشتيه بايلوَزيـكانى سـردهمى خوّيهتى و نهوه به نهوهش دهيكوازيتهوه، ناو لهوهش دهنيت (يهرهسهندنى

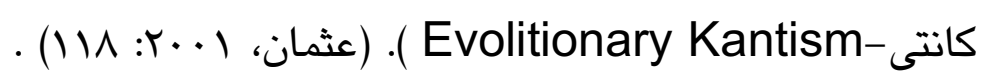

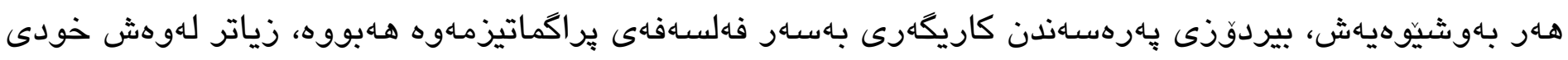

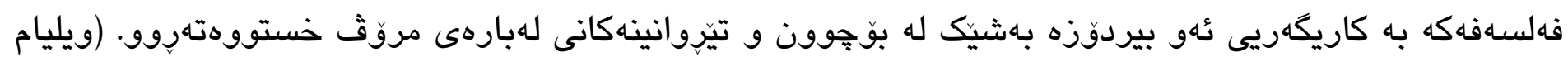

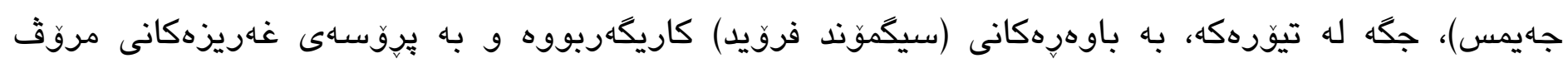
(Instincts)

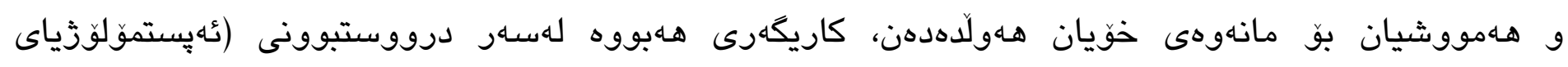

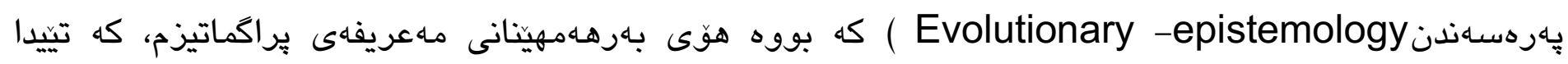
راستيى بيروكهكان و كردارى بهرجهاته و بـسوود بو مروق دهكاته درووشم، له بهرانبهردا خهيال و بوّجوونه

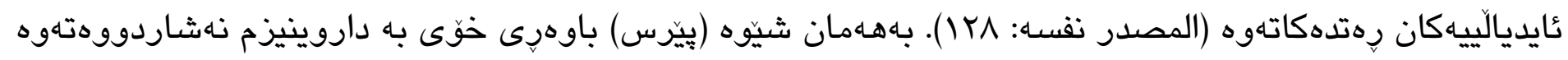
و يّيّيوابووه هيّز و رِاستهقينهبوونى كريمانهكان كرهنتى مانهوه دهكهن. تُهو كريمانانه دهبيت ملكهجى تاقيكردنهوهى

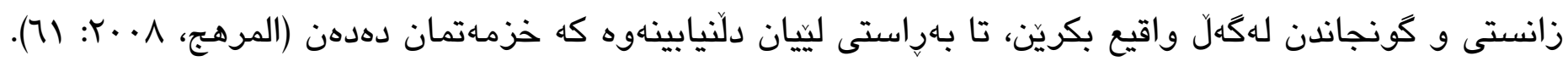

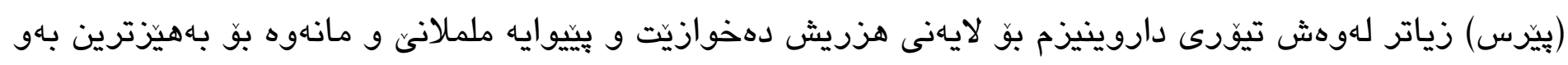

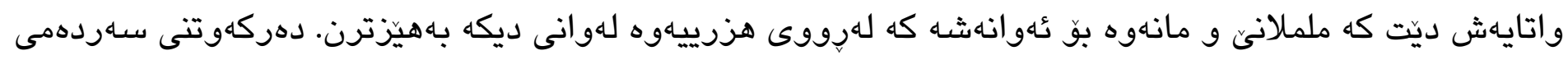

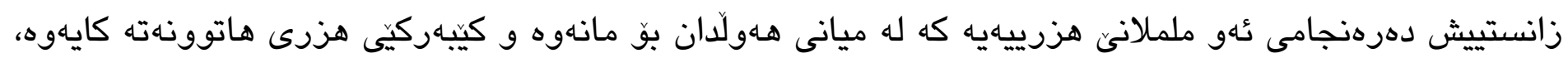

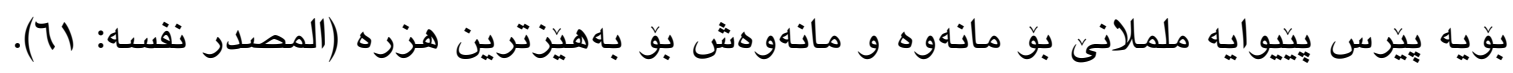

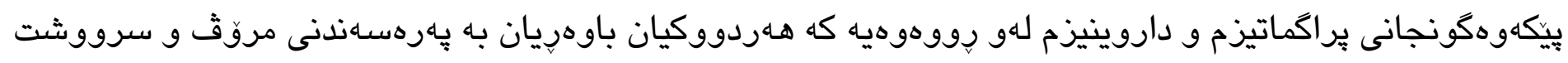

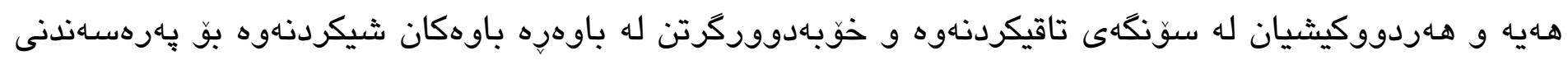

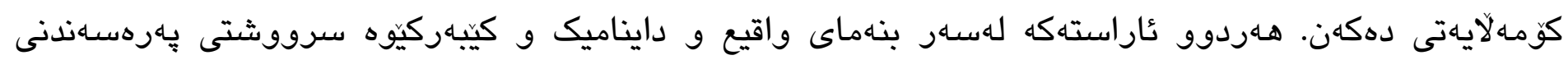




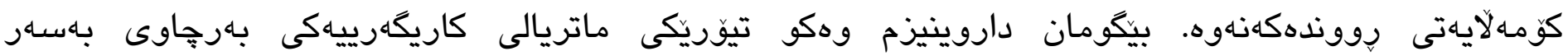
يراكماتيزماوه هـبووه.

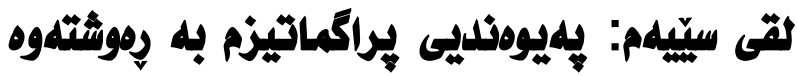

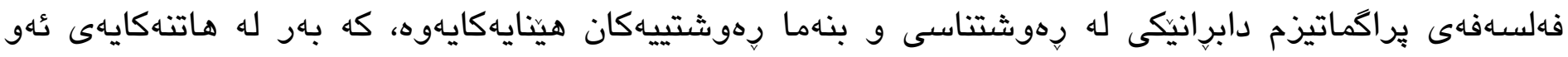

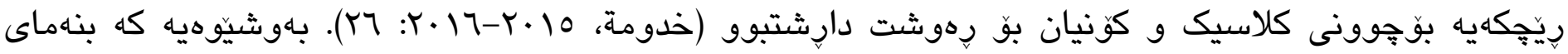
سهرهكى ئامانج و سوود بيت، برياردانى رهوشتى و نارِوشتيى هـه كاريّك به دهرهنجامى كارهكه دهبهستريتهوه

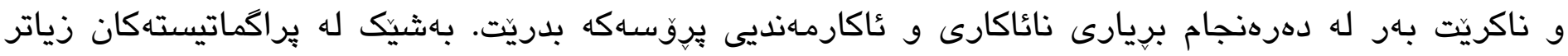

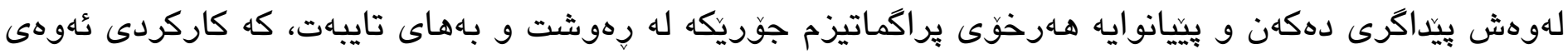

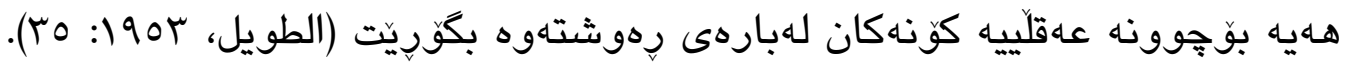
ئهو تيوّره رهوشت به حاقيقهتى كرداريياوه دهبهستيتهوه و ئهمه شهاهيوهسته به بهرهامى سوودبهخش. ئهوهش

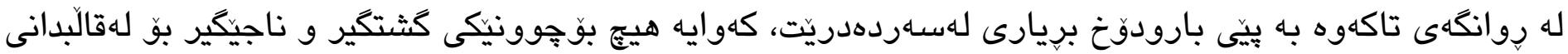

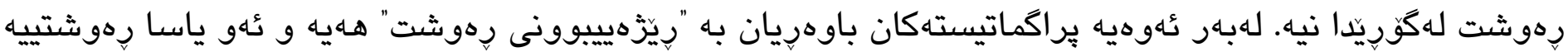

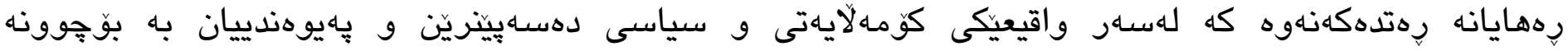

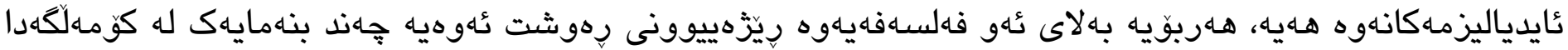

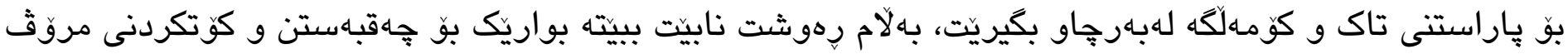

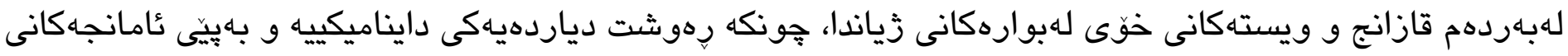

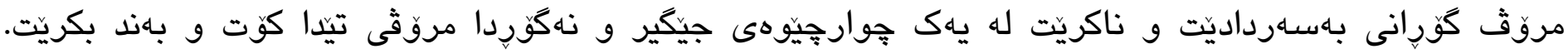

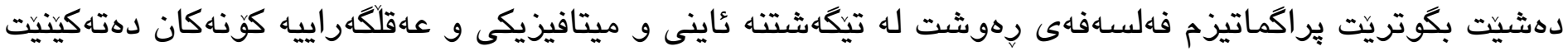

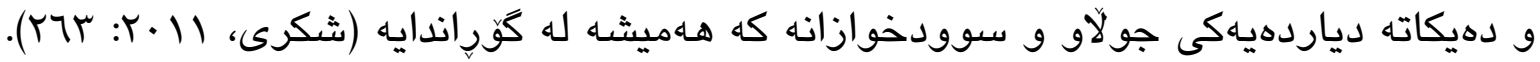

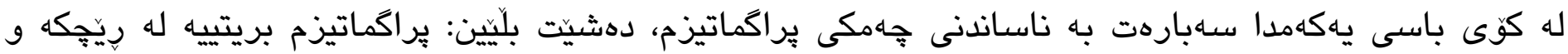

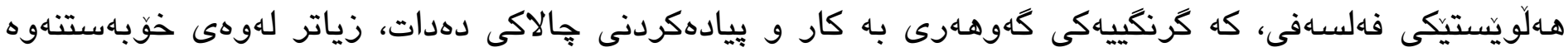
بيّت به هـلويّسته فكرى و كايديياييهكانهوه كه زقوبهى جار بهكرداركرنيان له زهمينهى سياسى و كومالآيهتيدا قورسه، بهو ئامانجهى لهكهل زهمينهى يِيّويستدا، دهرئهنجامئكى ساركهوتوو و واقيعييانه له كردار و جالاكييهكه بكهويتهوه و به سوود و قازانج بشكيتهوه، ههر ئهوهش به بنهماى حهقيقهتبوون و راستى دادهنيت كه دهتواندريتي به روونى دهرئهنجامى جالاكييككه بيينريت و سوودى ليّ بكهويتهوه. يُراگماتيزم دهرهنجامهكان وهكو بيّوهرى

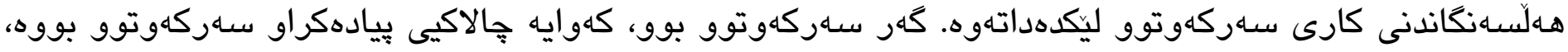

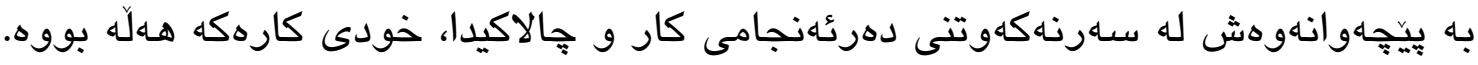




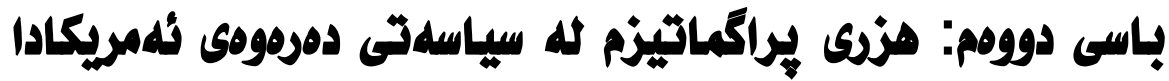

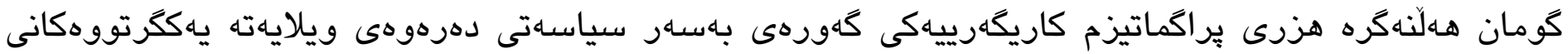

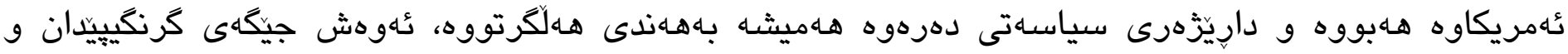
شيكردنهوهيه.

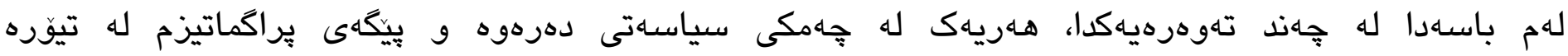
نيّودهولَهتيهكان و يِيكّهى براكماتيزم له سياسهتى دهرهوهى ئهريكا بهجيا خراونهته بهرباس. له تهوهرهيهكى ديكهشدا بهراوردى يِيادهكردنى بِراكماتيزمى ئيدارهى (باراك ئوباما) و (دونالّد ترهمب) كراوه.

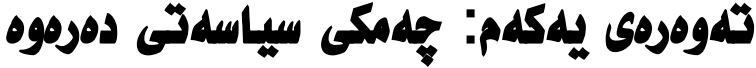

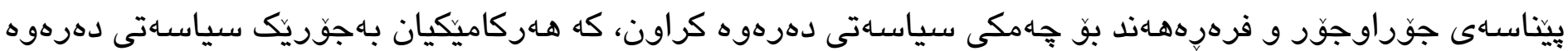
شيدهكهنهوه و بنهماكانى دياريدهكهن.

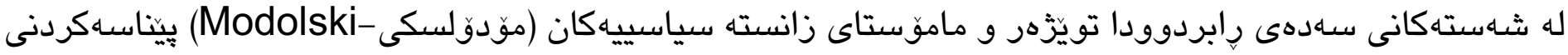

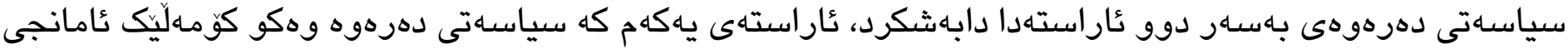

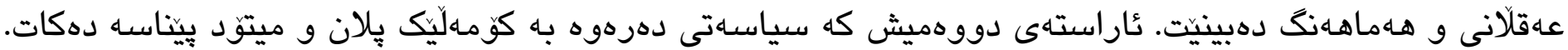

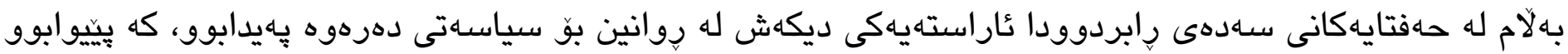

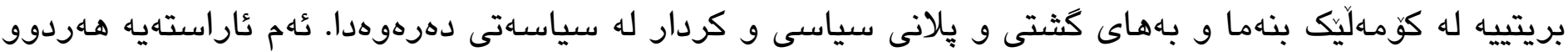

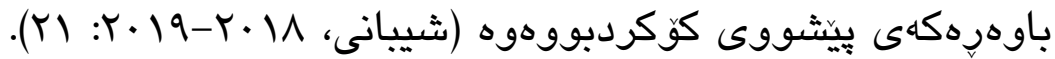
بهشيك لهو يِيناسانه سياسهتى دهرهوه به باوهر و خواستهكانى برياردهرانهوه دهبهستنهوه. ليّرهدا يهكيك له

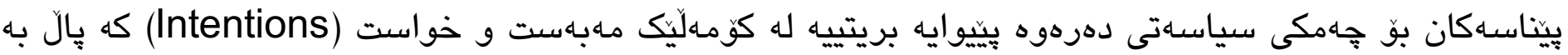

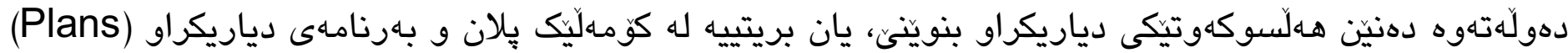

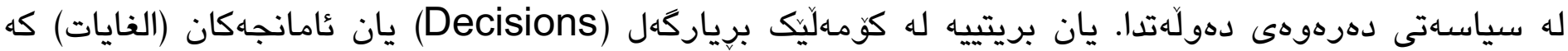
دهولّه بو بهديهينانى خواست و ويستهكانى دهيانكريتهبهر. له هـهان كاتدا كوزارشتيشه له كومهلّيّ بنهما و تيكّيشتنى كثتيى دهولّت(General Principles) كه جلّهوى كار و كاردانهوهى دهولّهت و جالاكييهكانى له

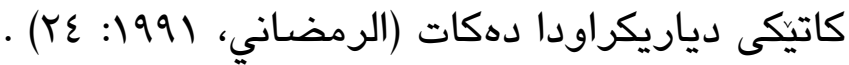
هـروهها سياسهاتى دهرهوه ودكو كومهليّك جالاكيى يهك لهدواى يهك (Activity) دهبينريّن كه برياردهر له سياساتى

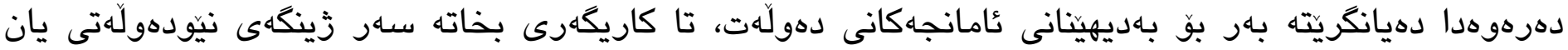

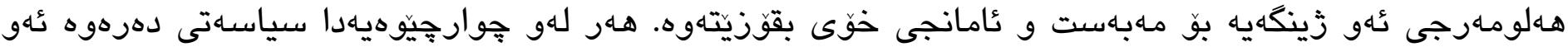


كاردانهوانهش (Reactions) دهكريتهوه كه زينكهى سياسهتى نيّوان ئهكتهره نيّودهولَّتييهكان بهاسهر دهولَهتيدا دهساءيتين (المصدر نفسه).

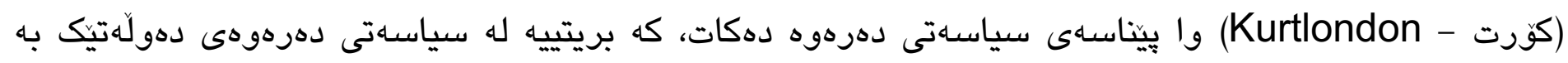

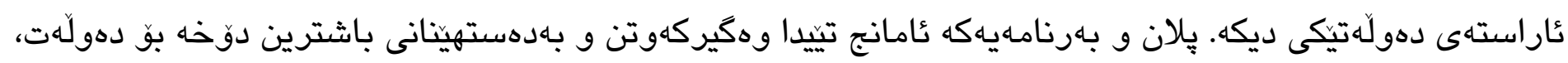

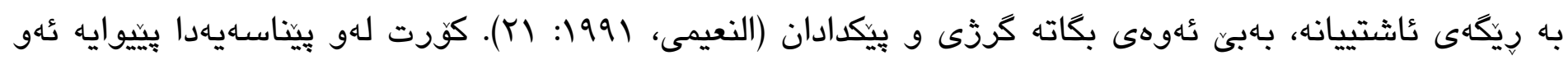

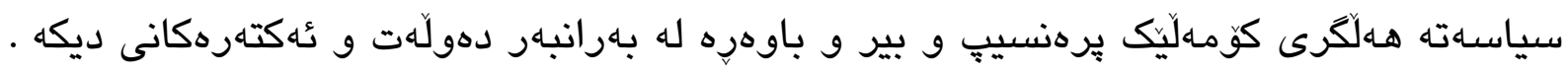

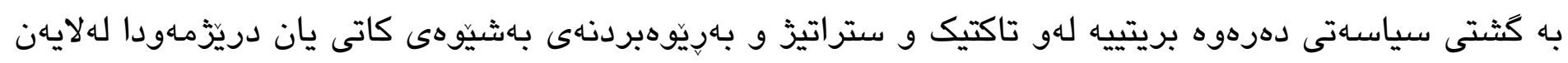

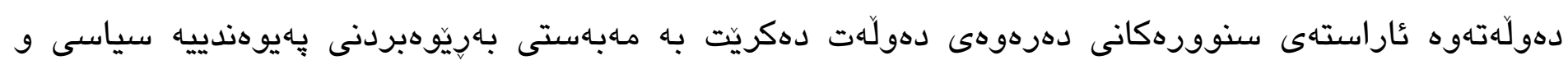

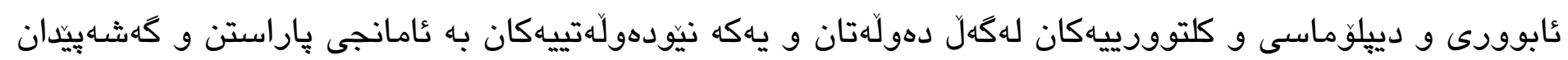
و بهاهيَزكردنى دهولّهت.

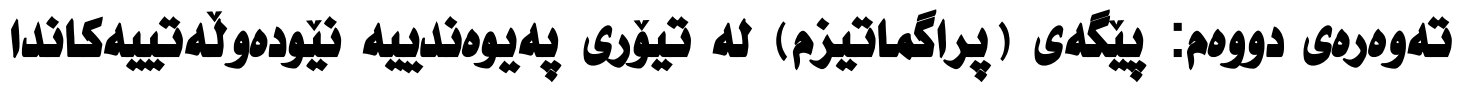

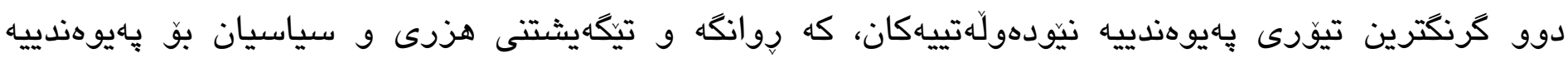

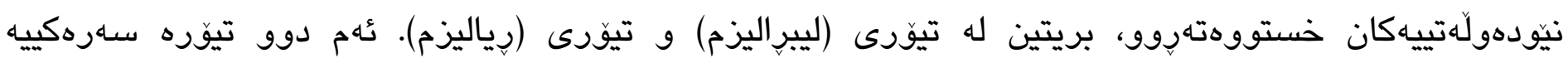

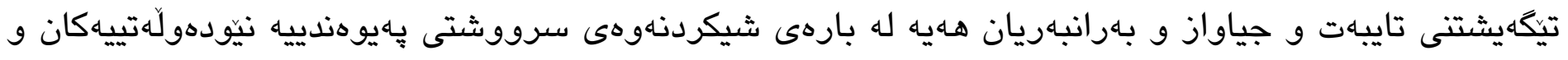

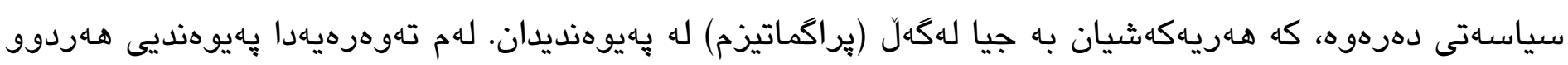

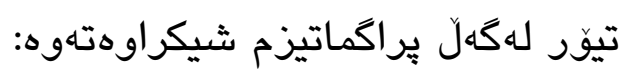

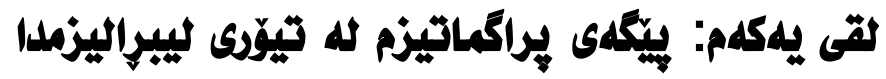

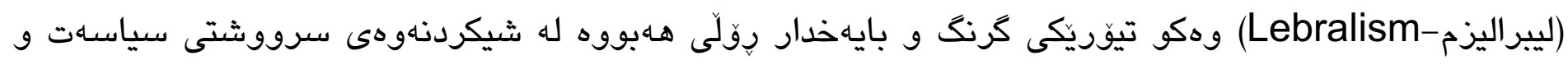

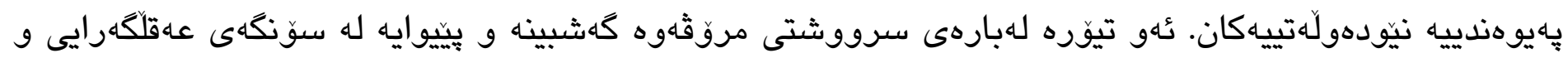

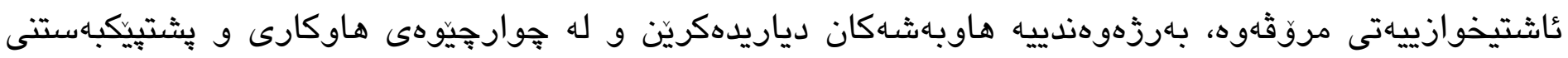

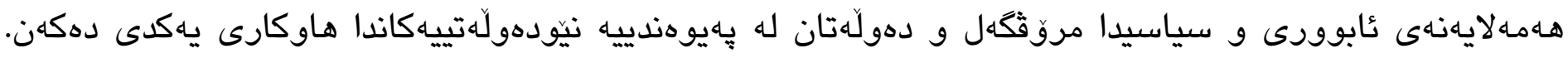

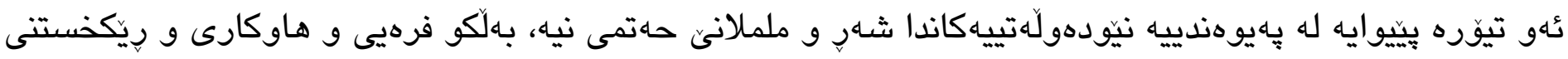

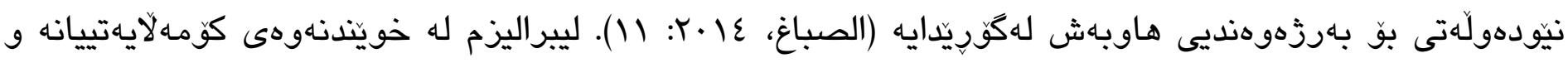

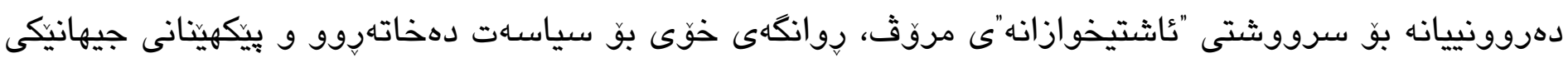

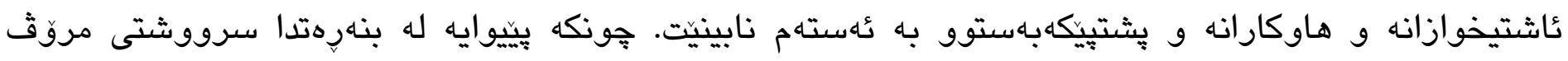

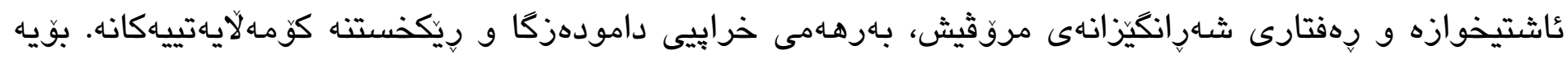

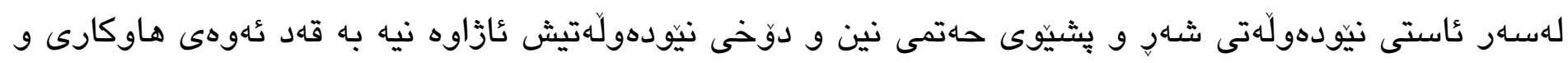

DOI:https://doi.org/10.26750/Vol(8).No(3).Paper27 http://journal.uor.edu.krd/index.php/JUR Vol.8. No.3,September.2021 


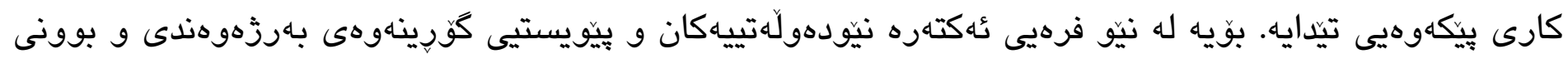

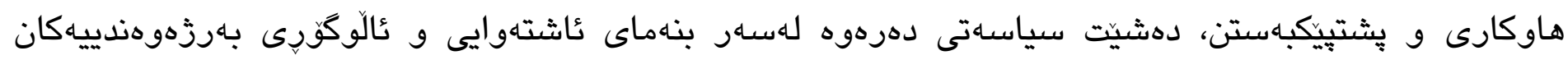

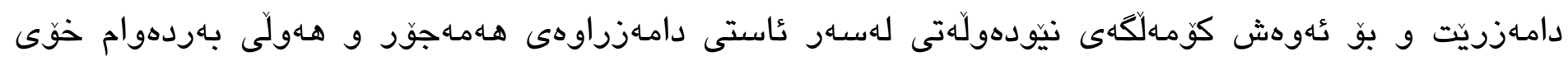

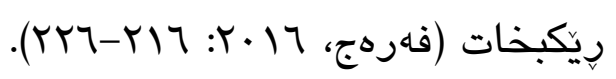

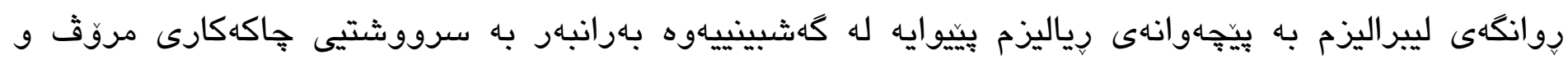

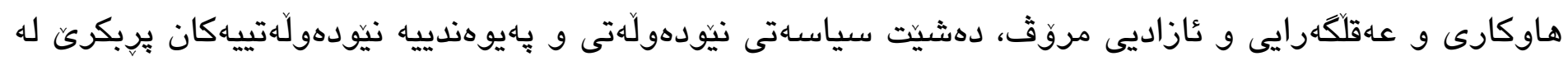

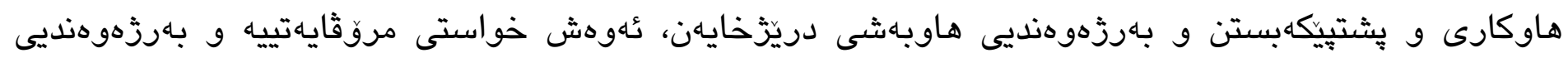

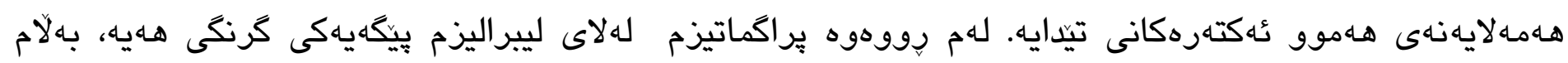

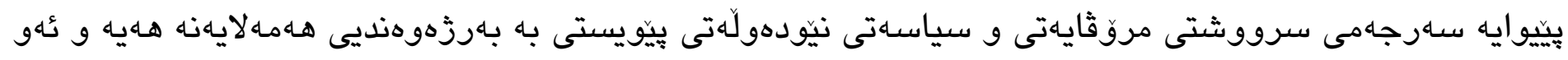

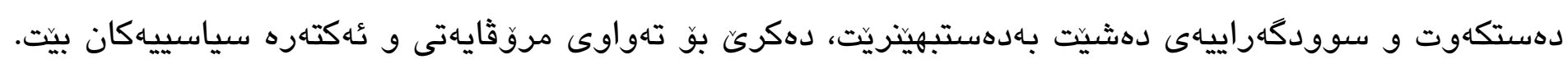

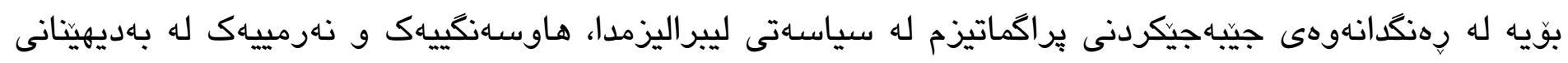

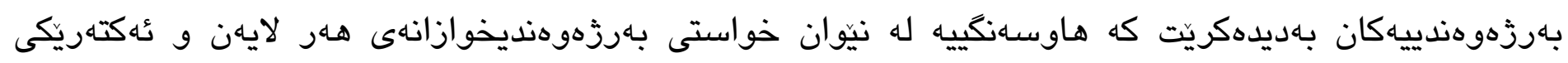

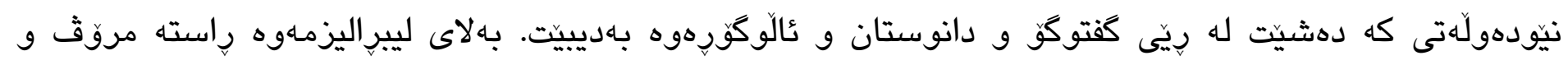

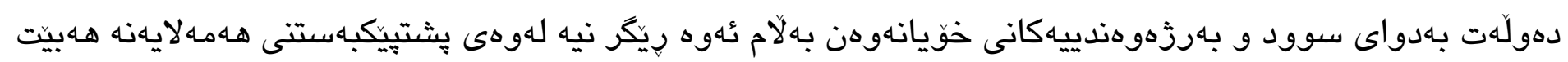

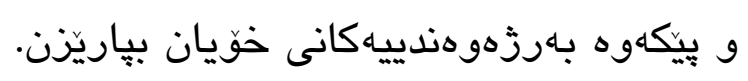

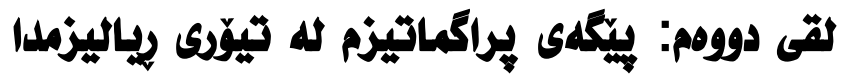

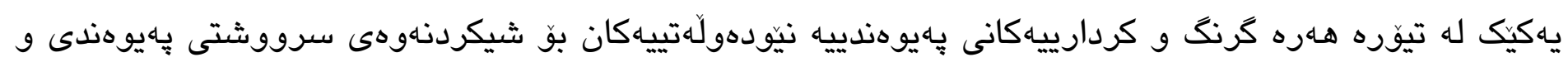

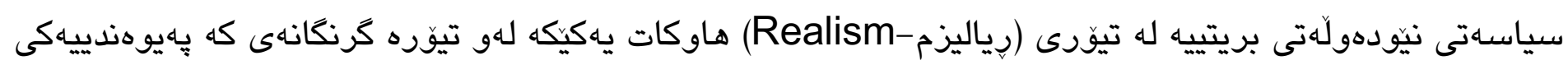

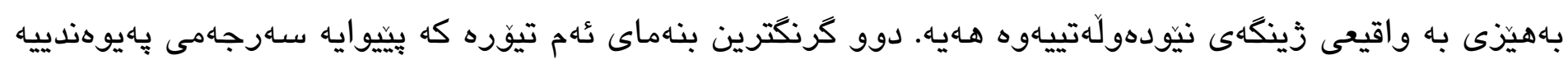

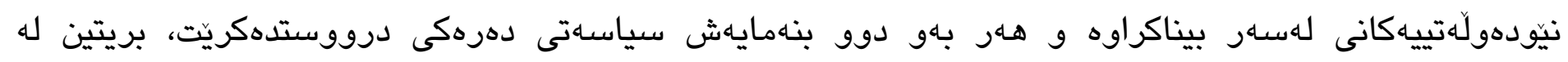

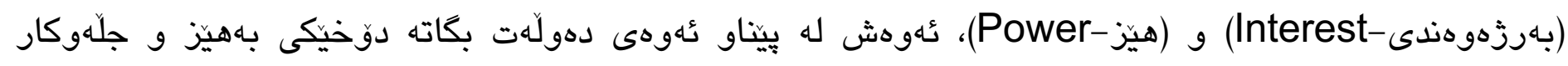

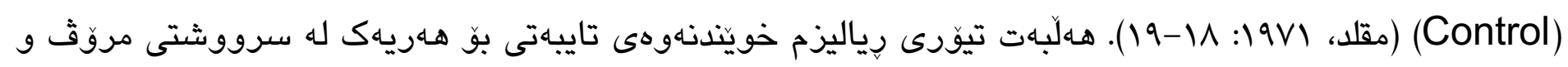

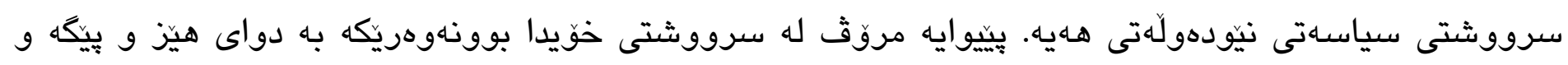

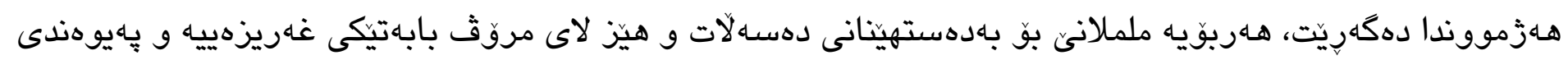

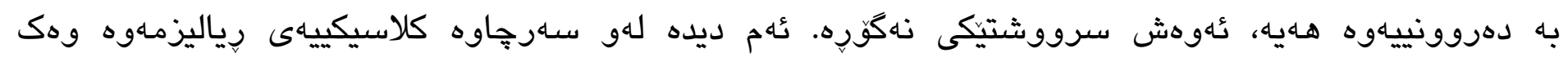

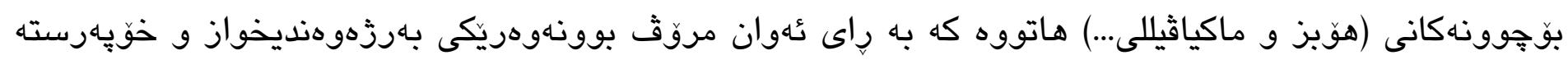

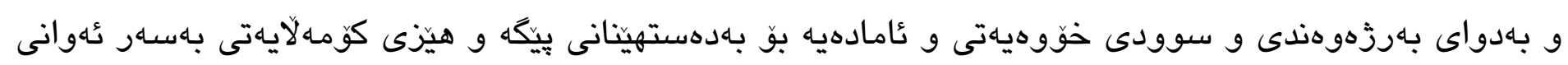

DOI:https://doi.org/10.26750/Vol(8).No(3).Paper27 http://journal.uor.edu.krd/index.php/JUR Vol.8. No.3,September.2021 


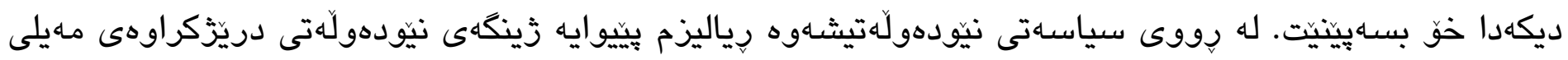

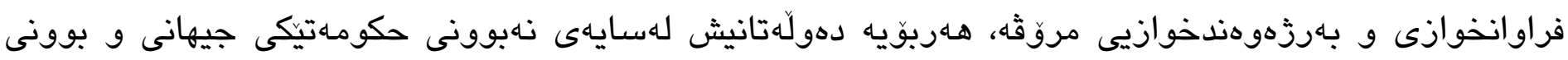

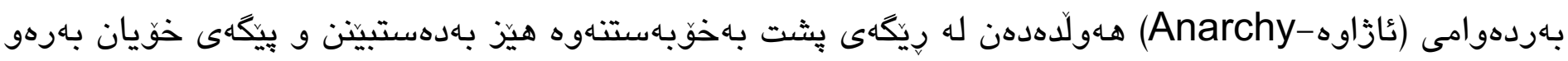

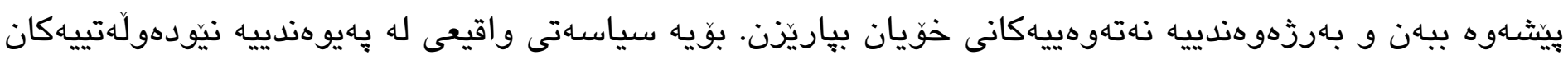

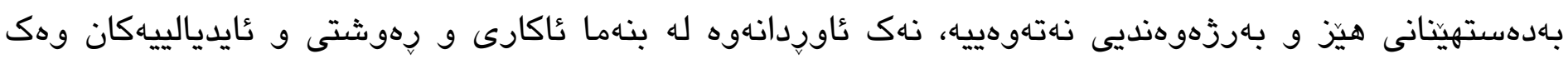

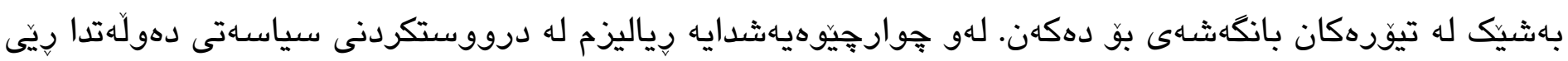

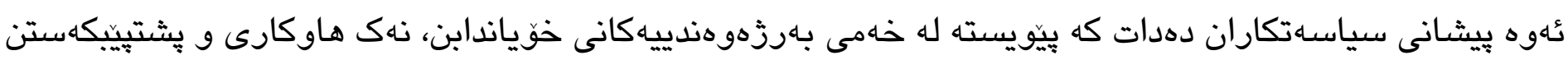

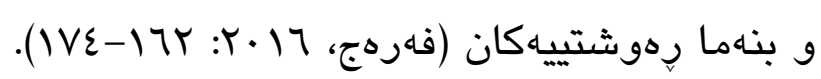

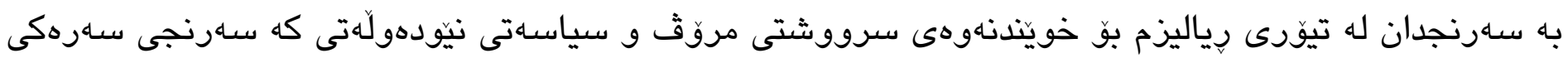

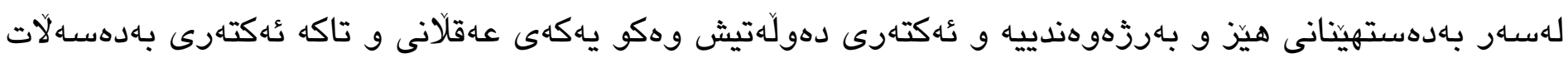

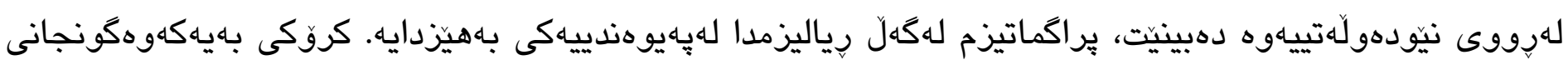

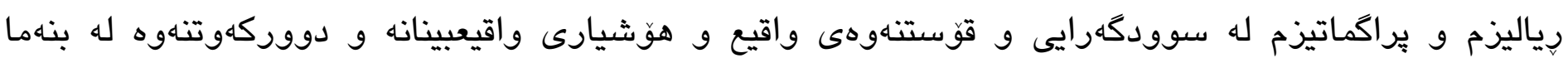

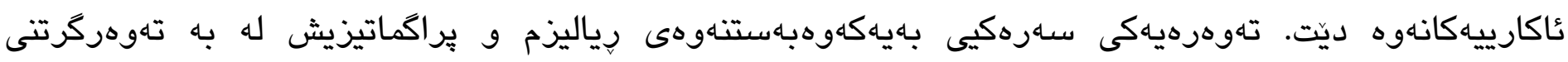

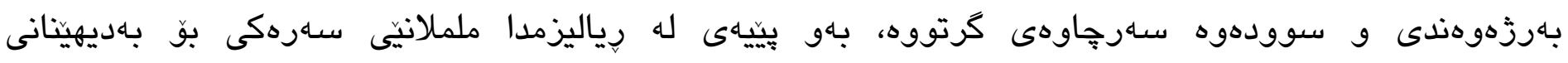

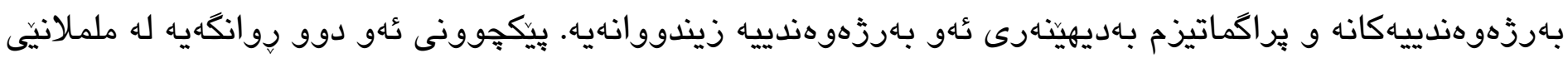

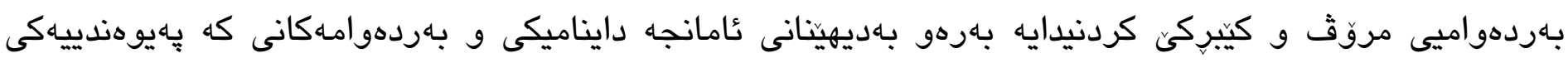

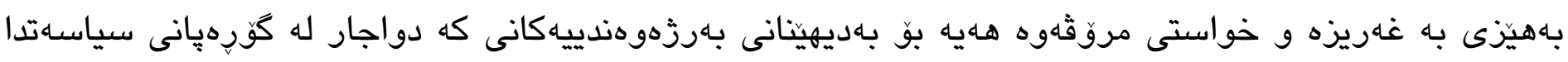

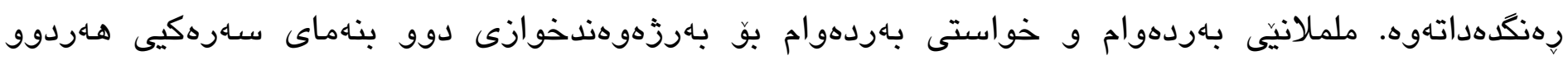

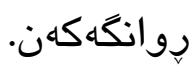

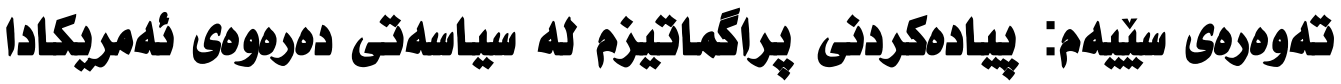

رهكوريشاهى فهلسهفهى يراكماتيزم كاريكهرييهكى بهرجاوى لهسهار هزرى سياسيى عُهمريكا و سيستهمى سياسيى

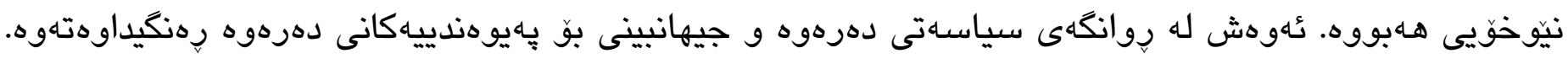

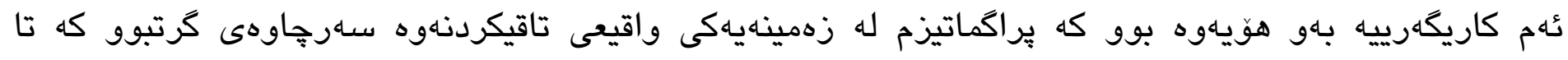

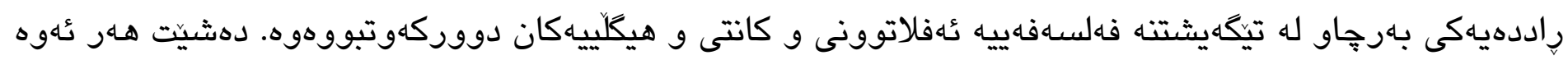

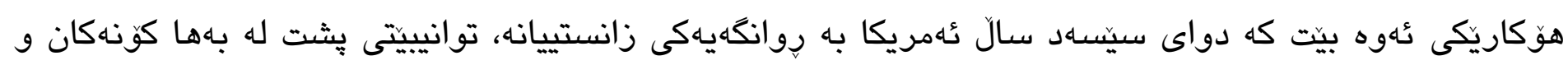

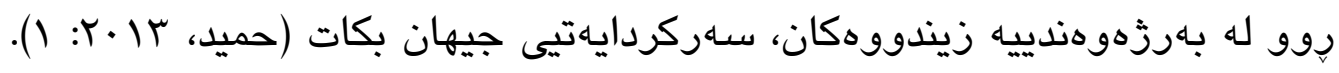




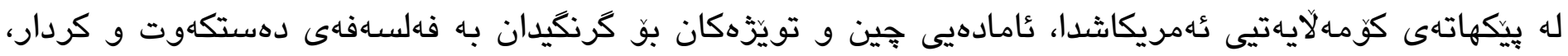

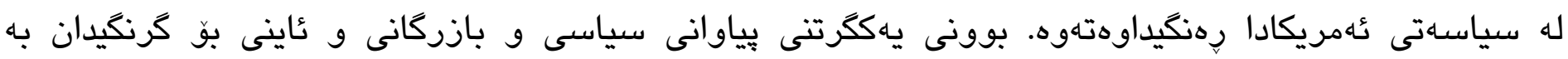

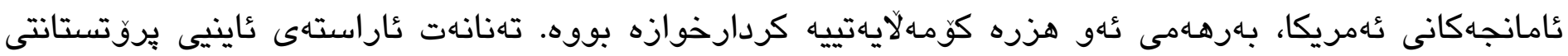

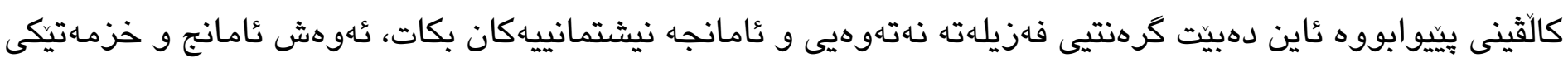

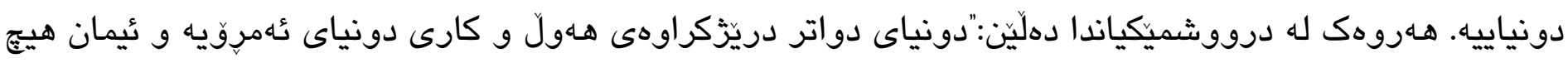

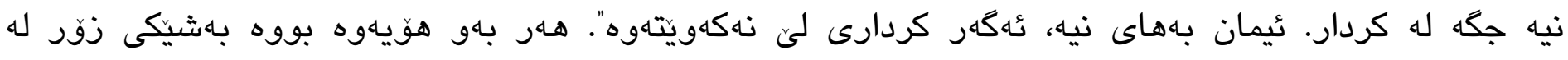

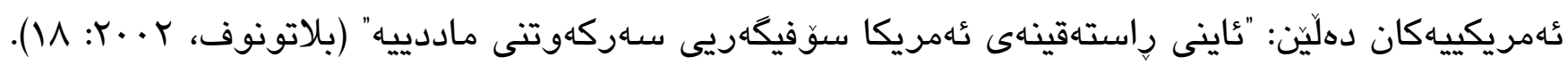

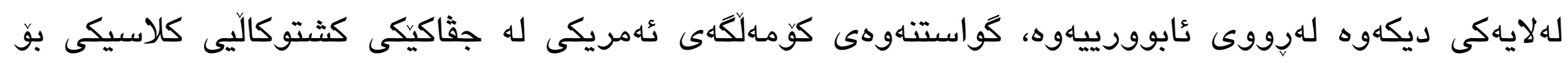

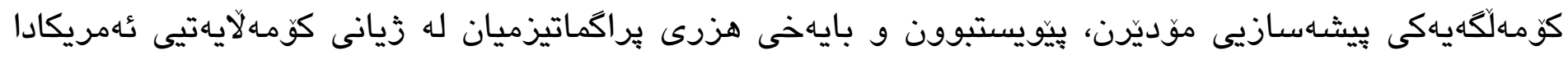

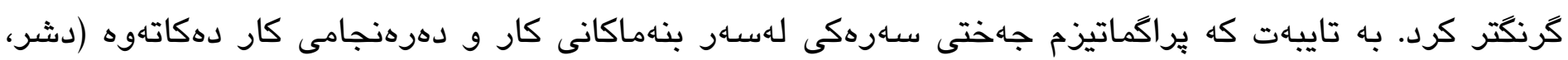

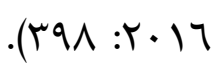

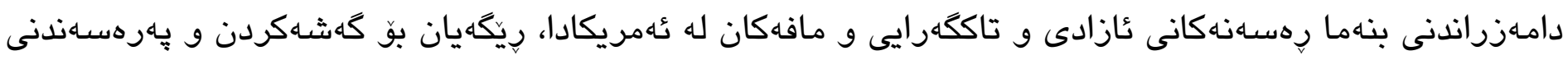

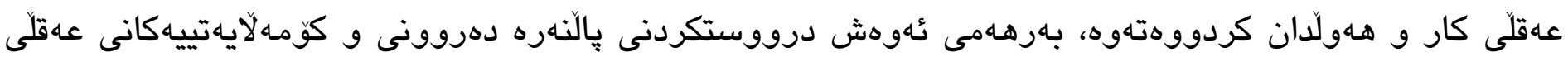

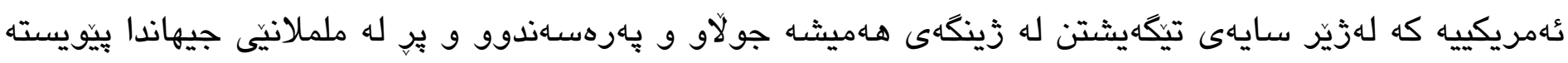

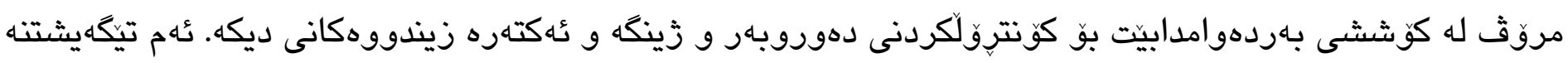

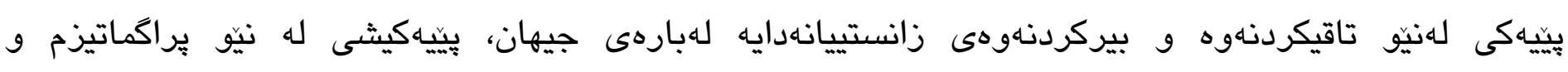
سوودكهراييدايه (المصدر نفسيه: 1).

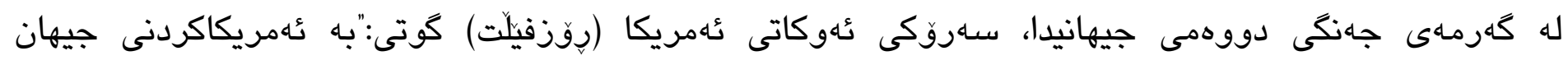

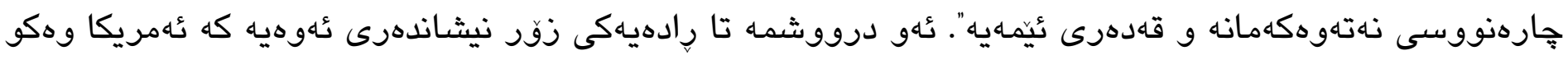

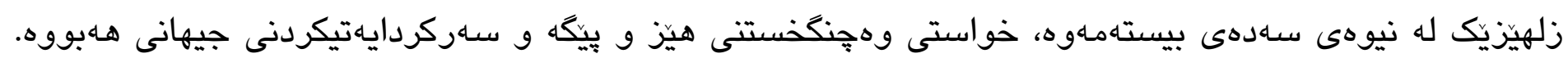

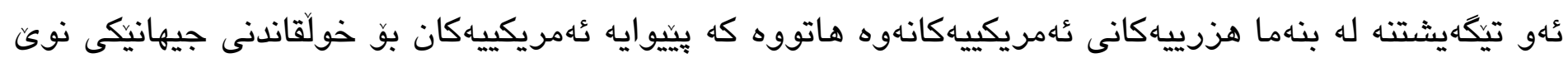

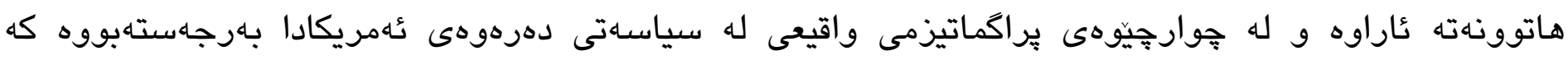

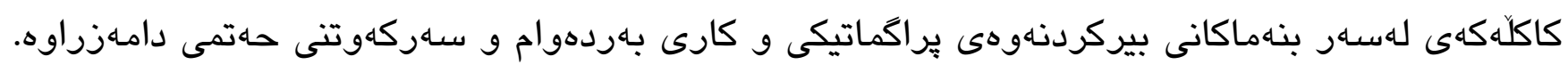

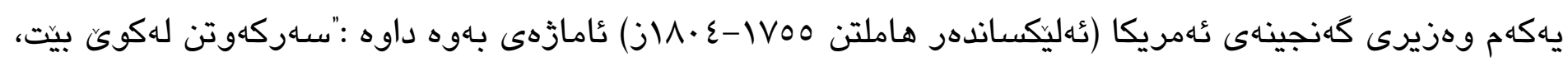

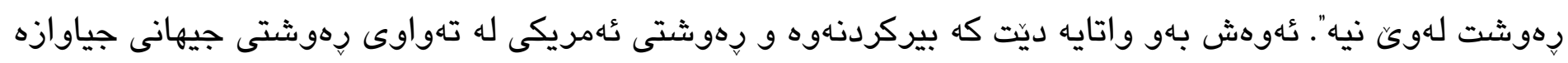

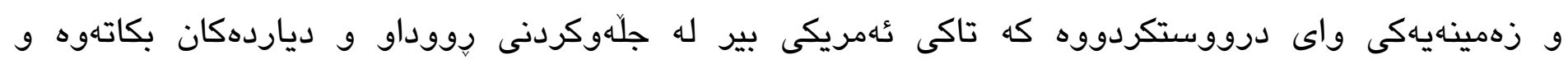

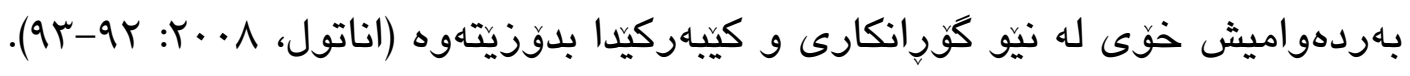




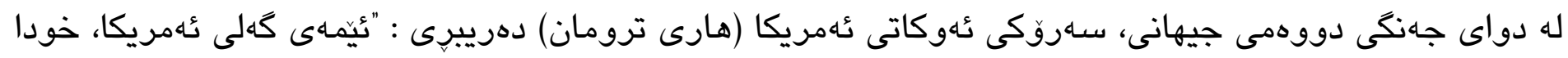

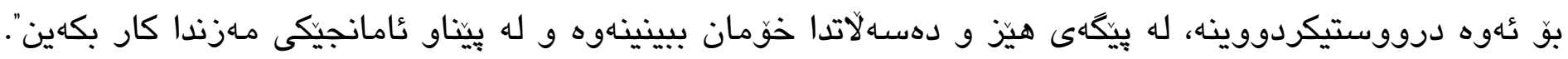

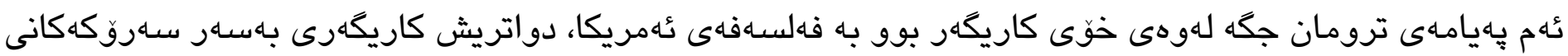

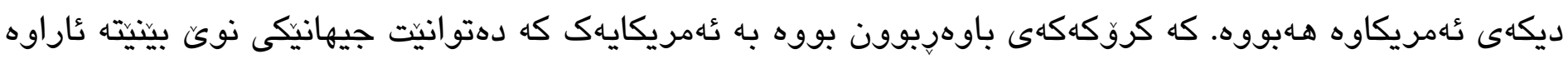

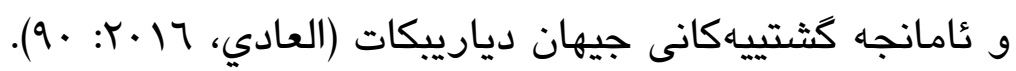

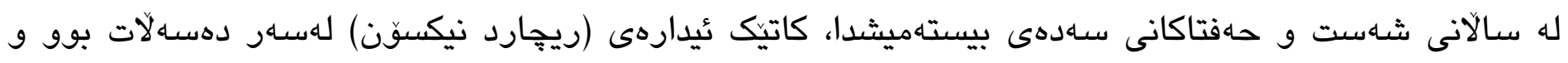

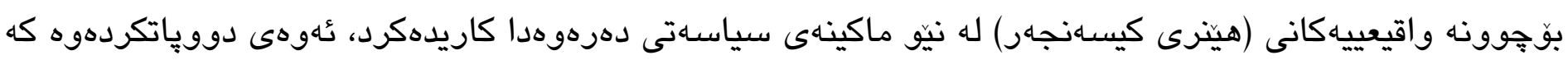

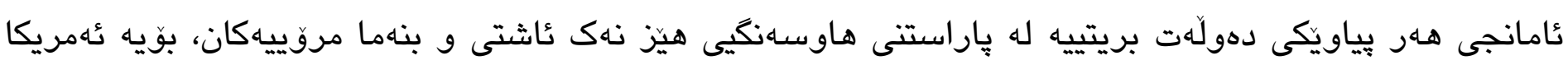

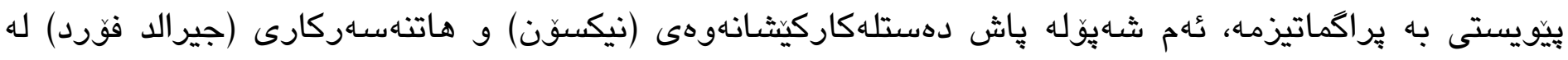

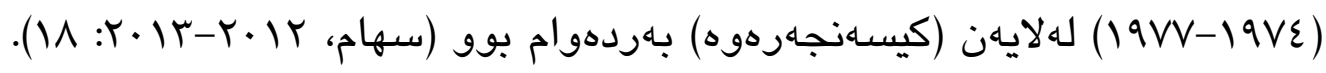

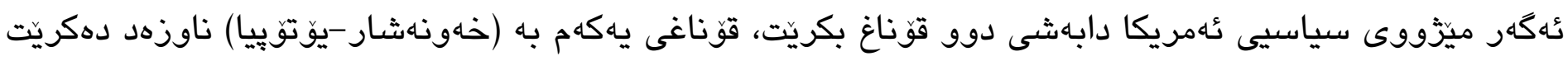

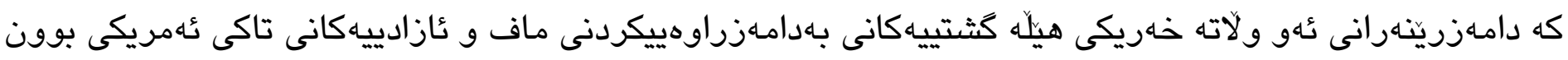

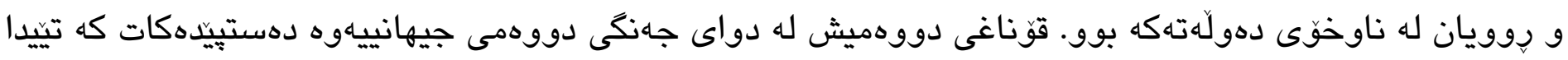

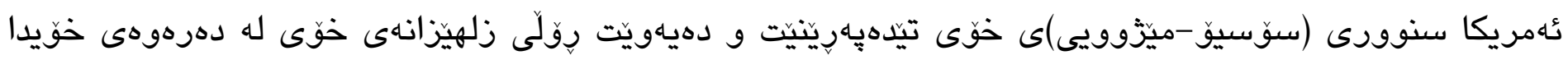

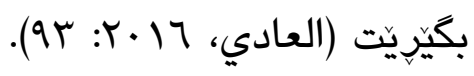

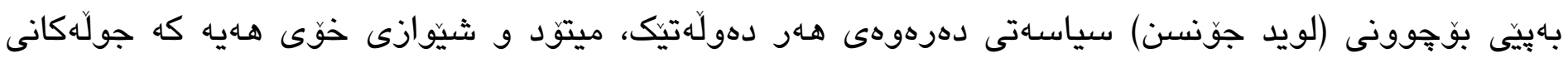

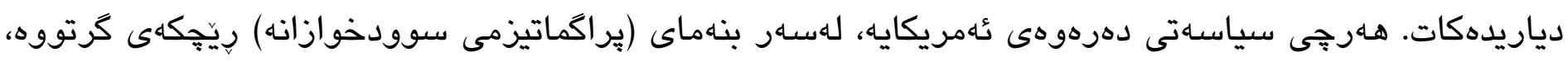

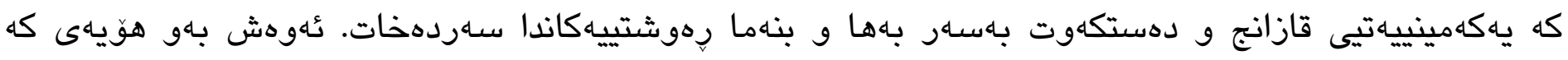

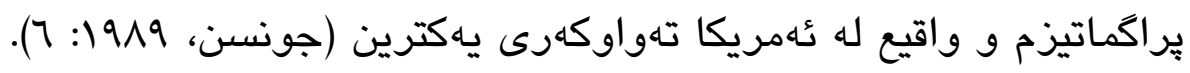

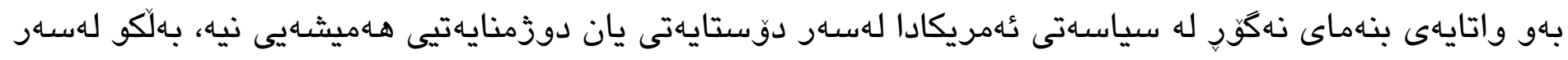

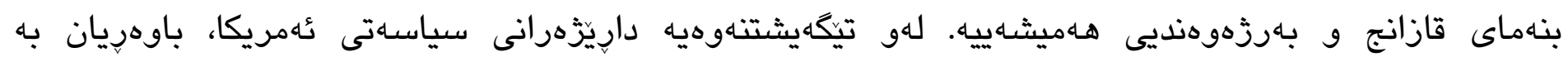

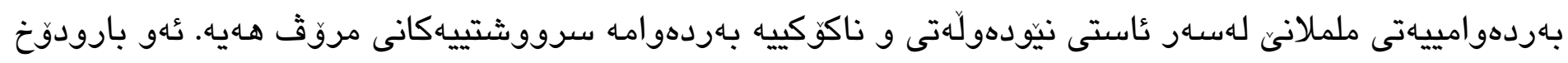

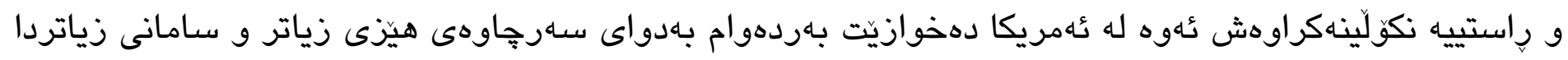

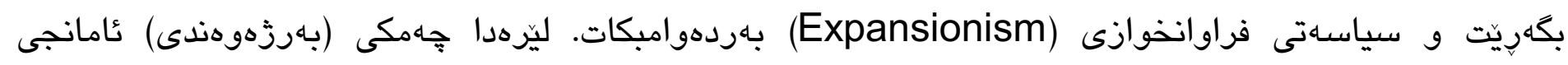

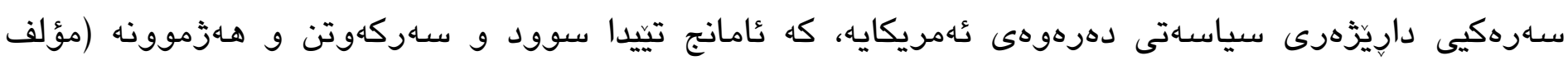

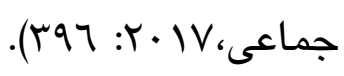

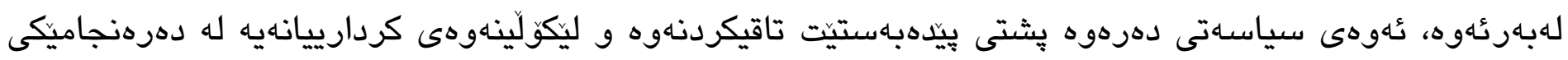

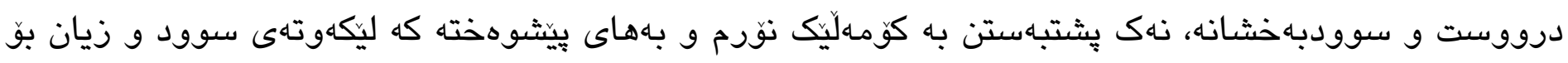




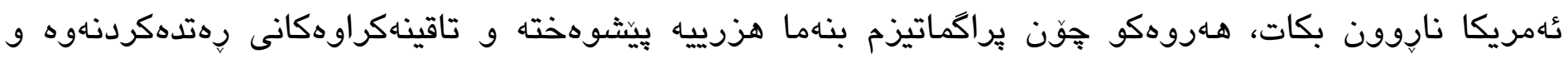

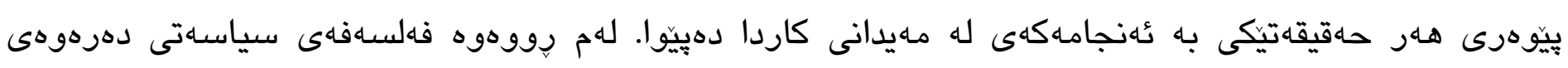

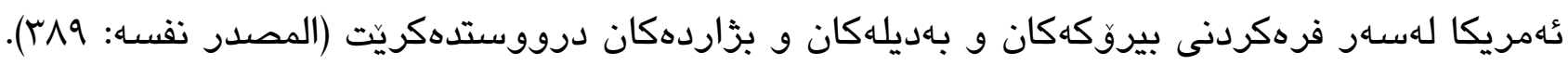

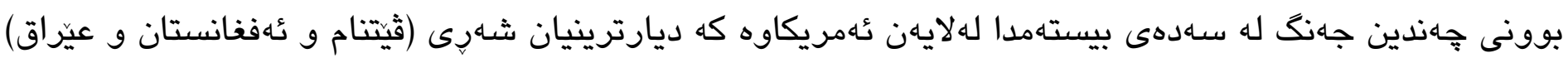

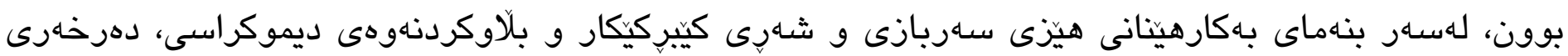

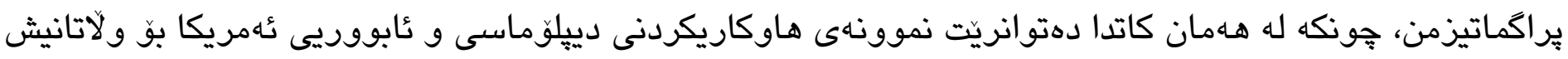

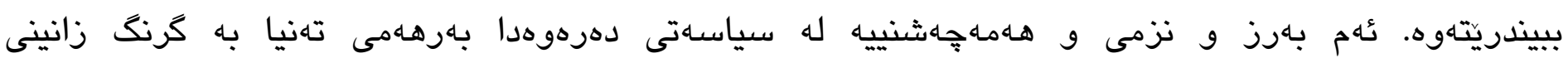

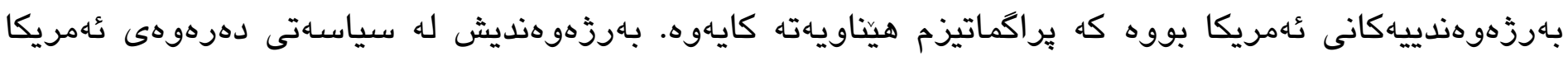

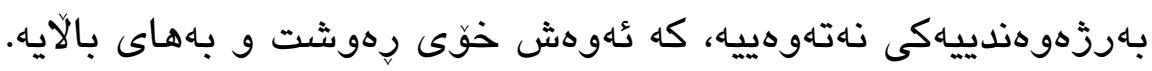

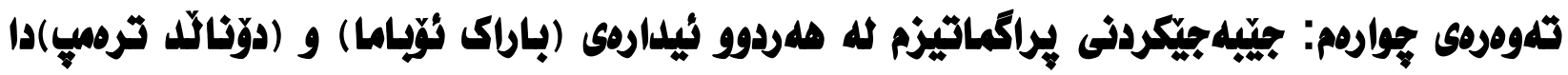

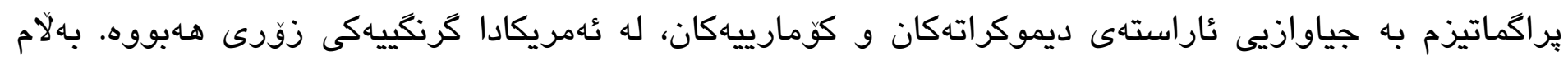

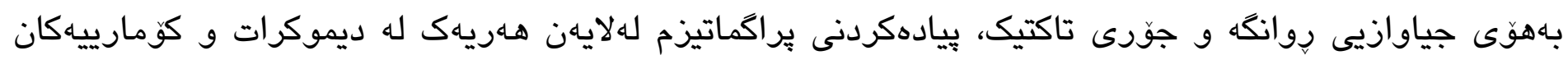

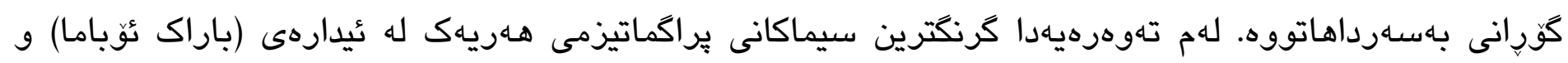

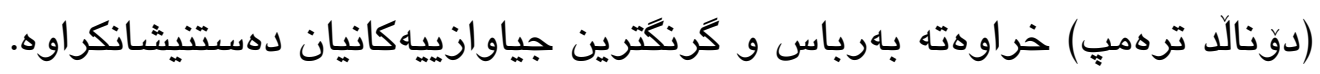

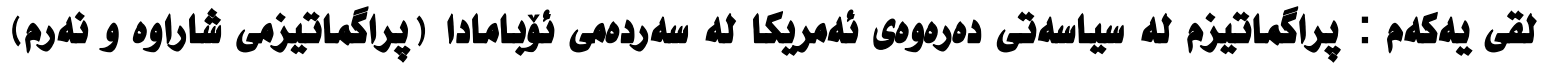

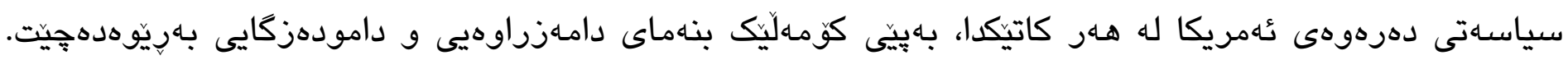

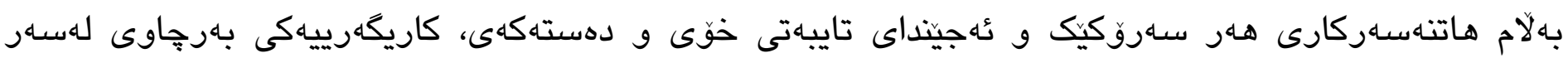

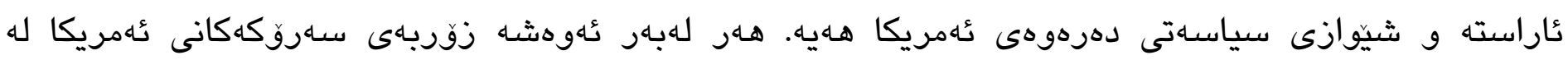

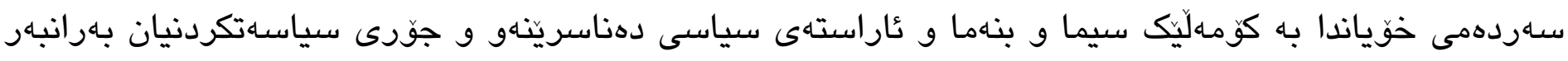

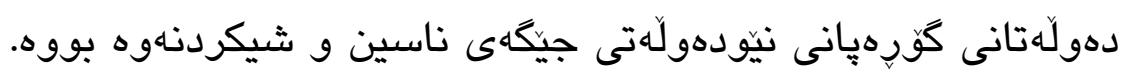

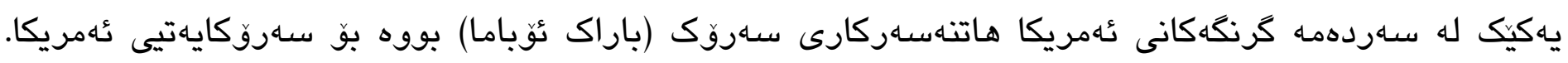

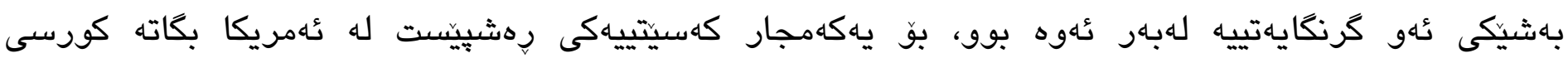

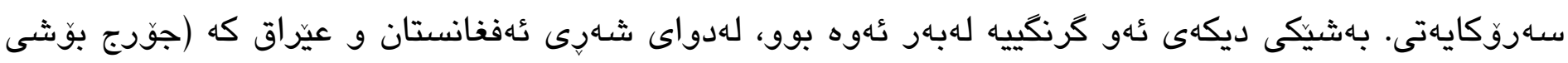

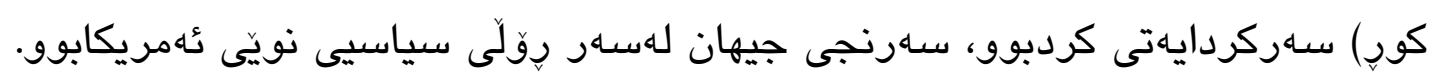

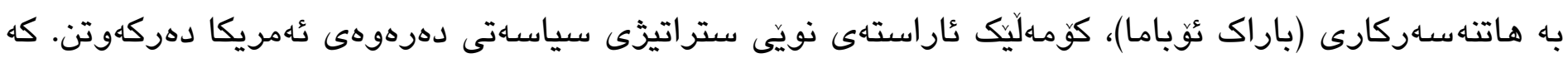

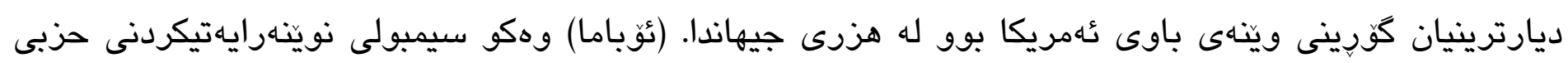


ديموكراتهكانى ئهمريكا، له دواى دوو خولى سـاروكايهتيى (جورج بوّش) كه بهكارهينّهى هيَّى سهاربازى و

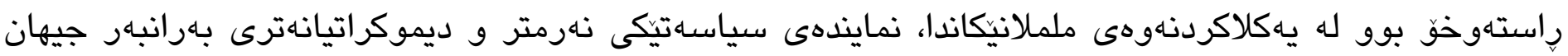

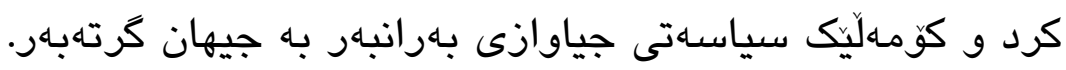

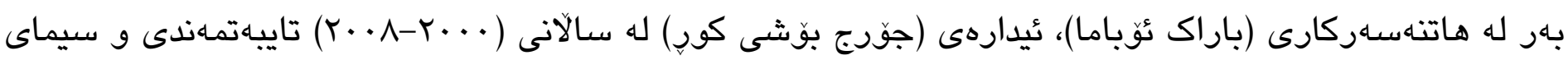

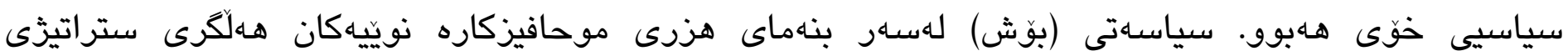

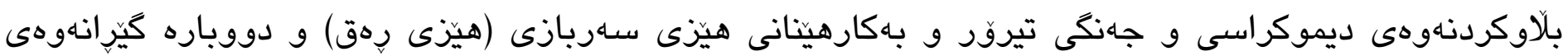

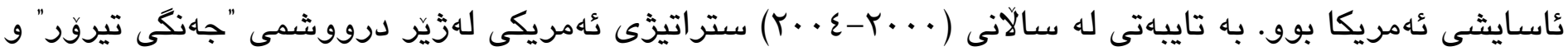

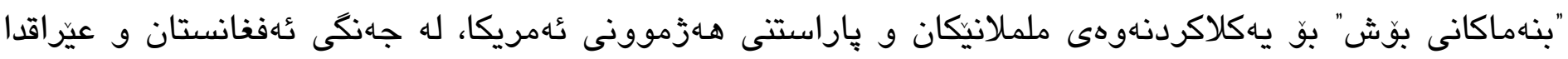

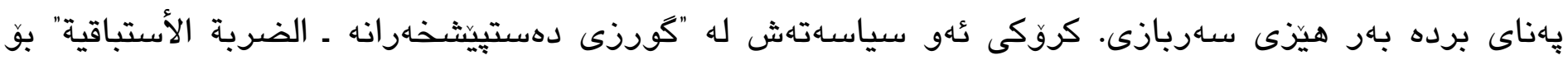

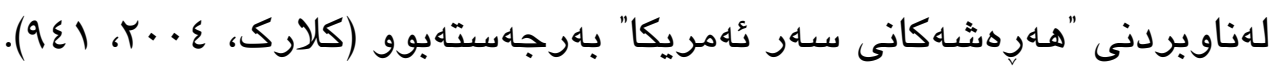

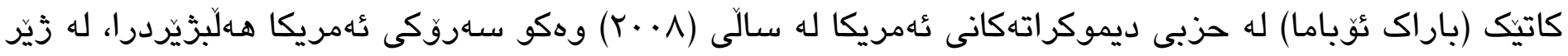

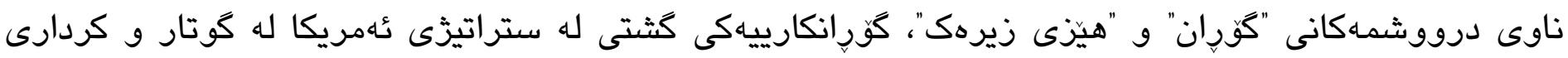

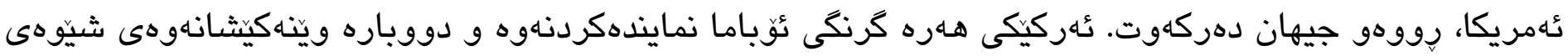

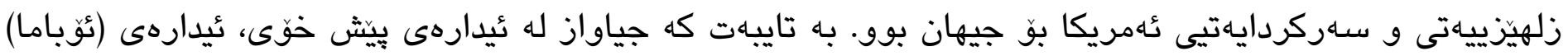

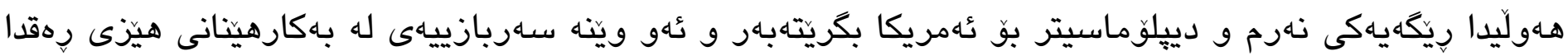

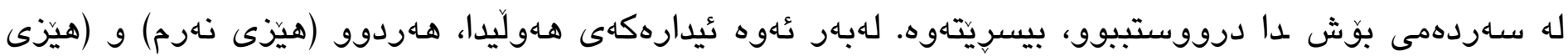

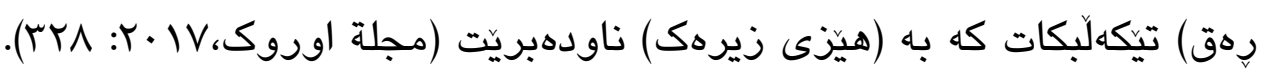

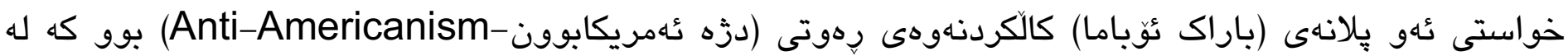

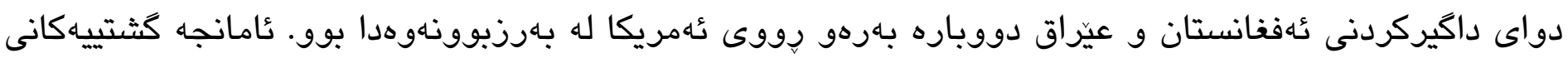

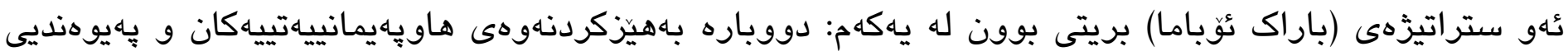

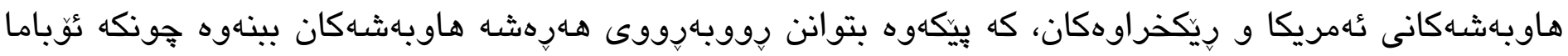

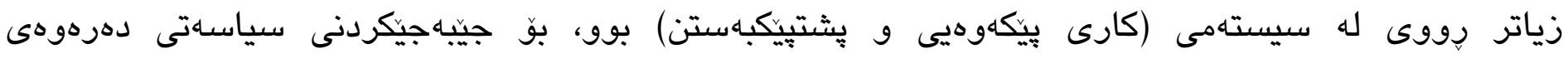

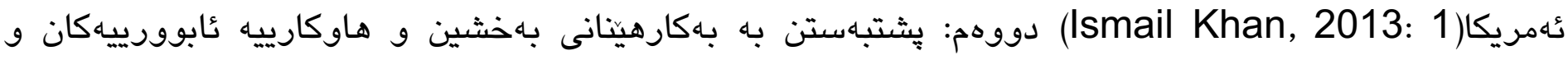

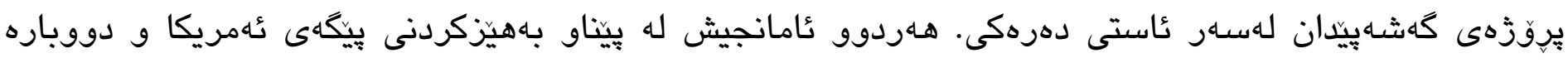

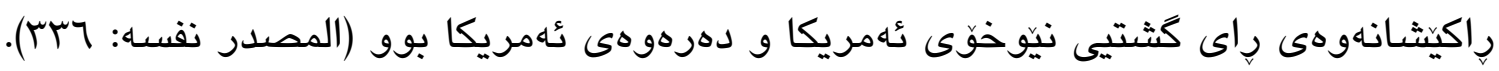

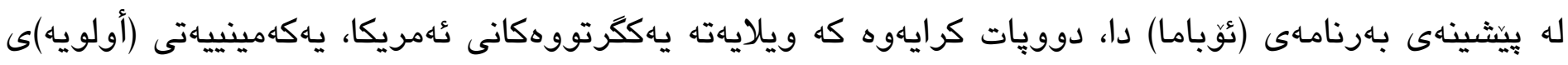

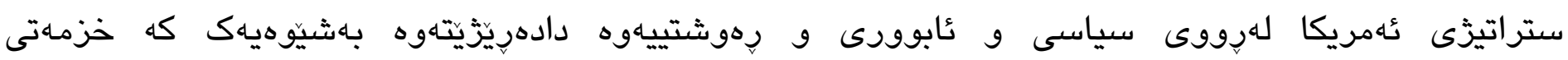

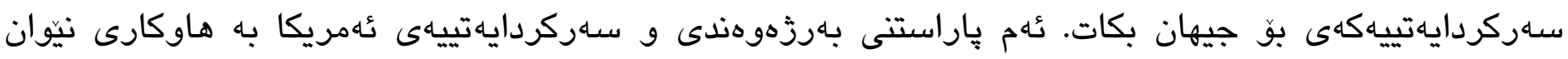




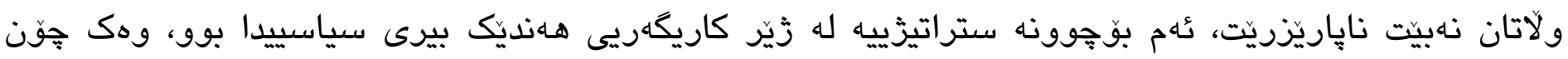

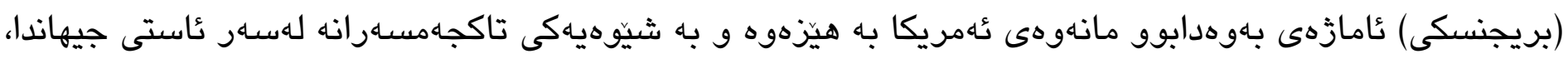

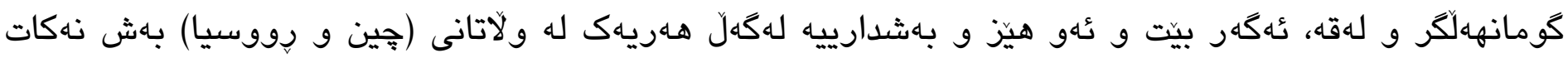

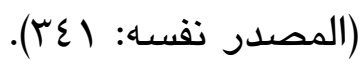

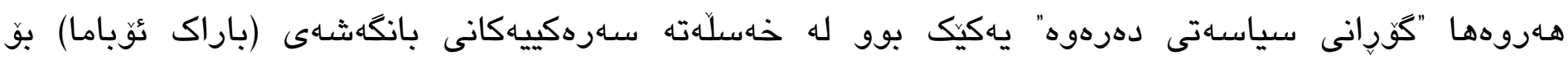

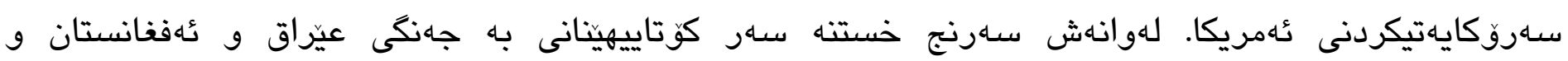
كثاندنهوهى بهرهبهرهى هيزّهانى ئهمريكا لهو دوو ولآته. لهلايهكى ديكهوه سهرنجى لهسهر ئهوه بوو دووباره

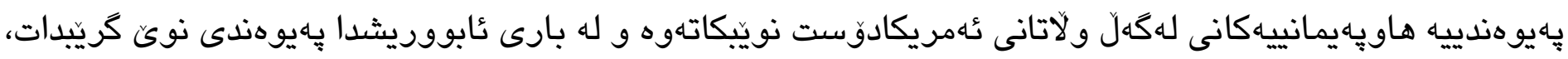

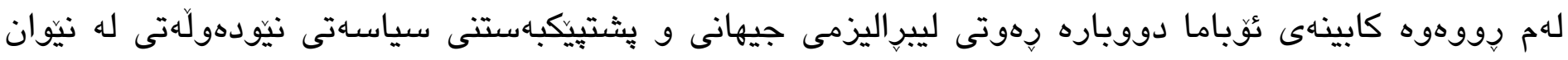

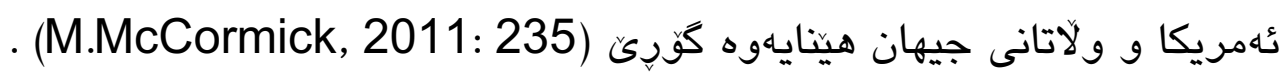

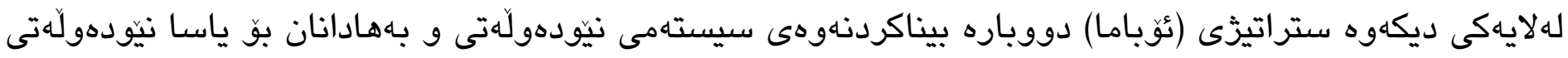

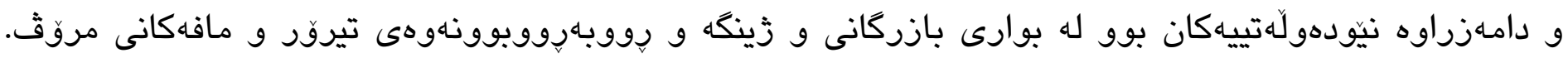

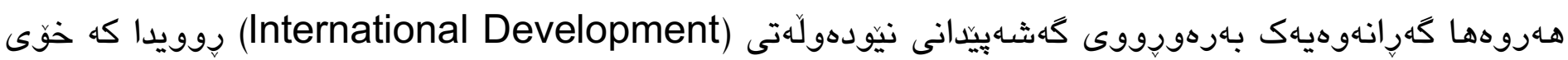

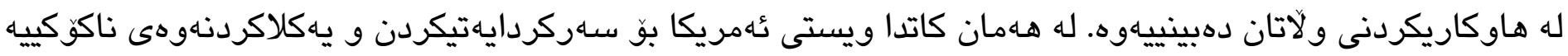

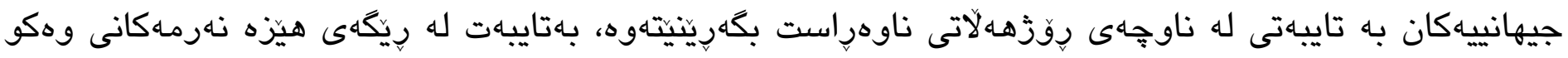

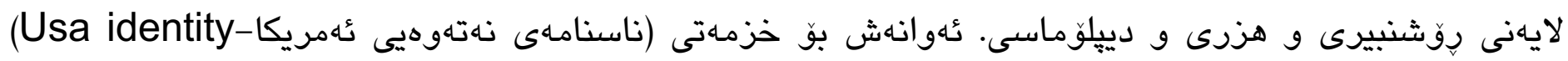

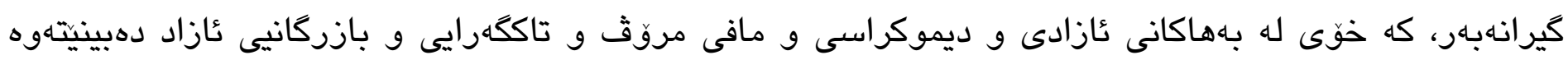

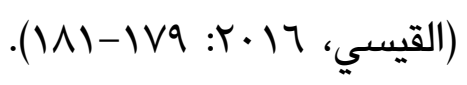

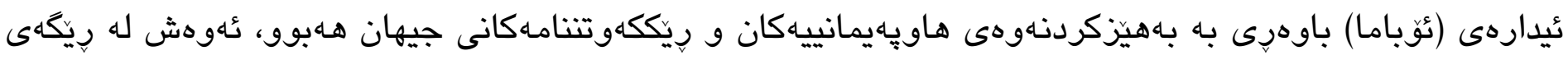

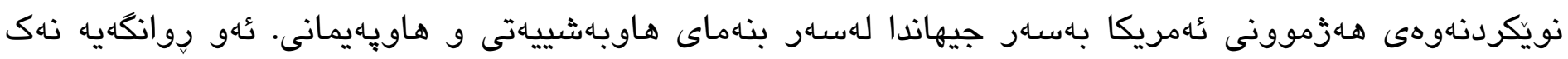

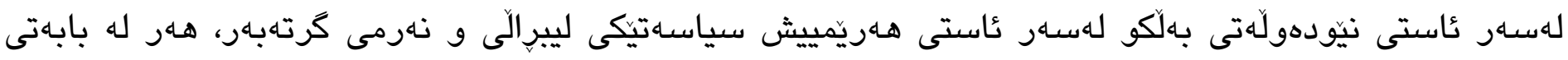

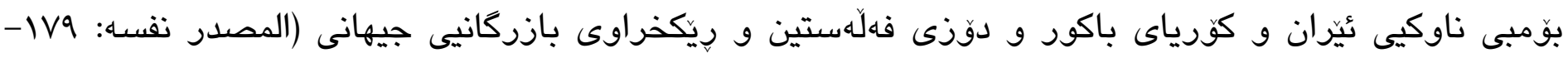

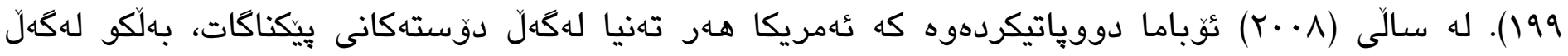

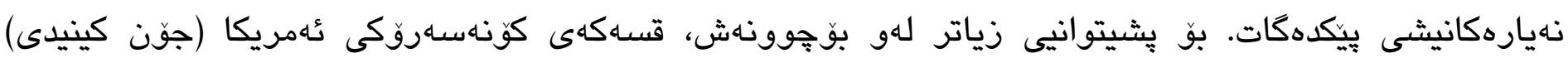

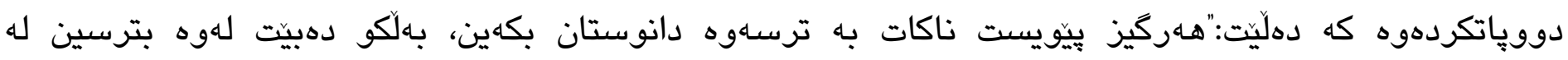

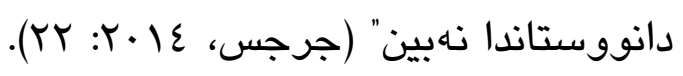

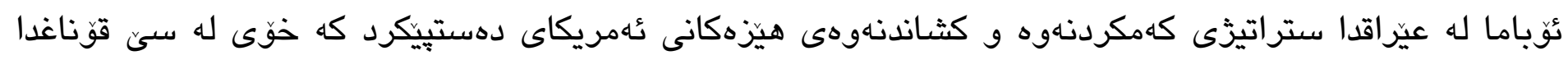

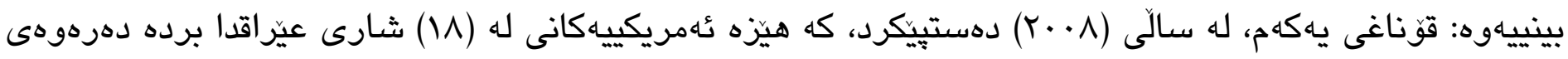




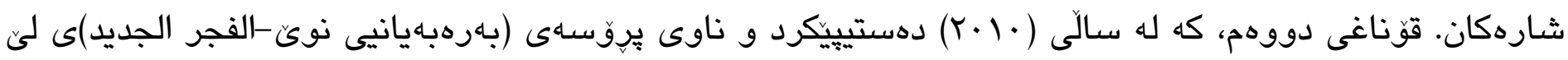

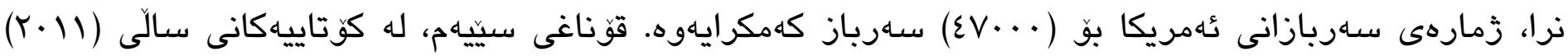

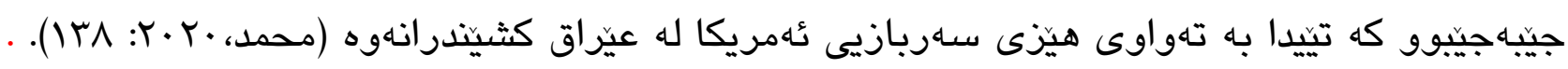

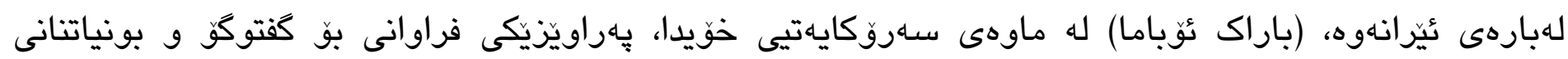

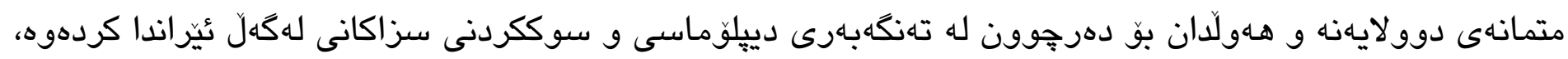

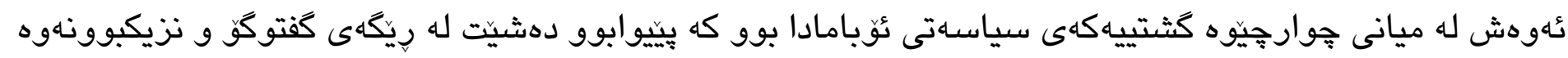

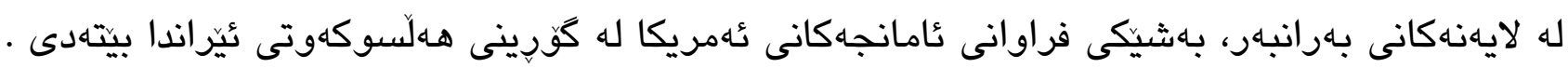

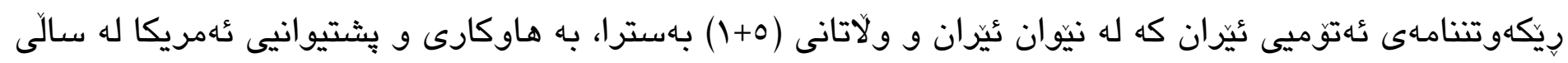

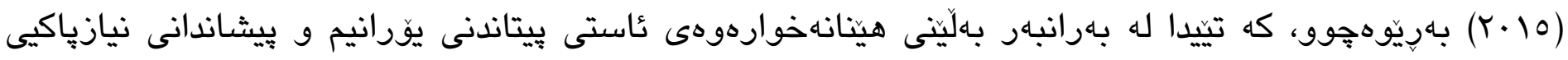

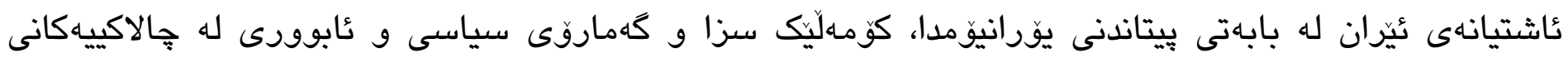

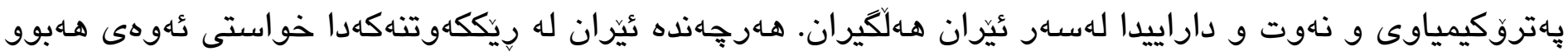

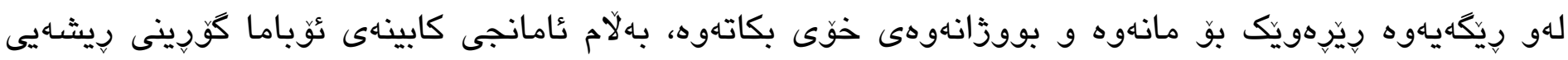

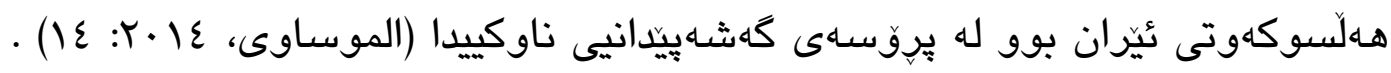

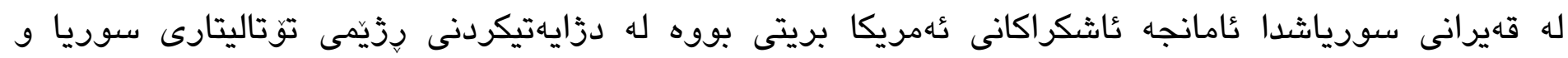

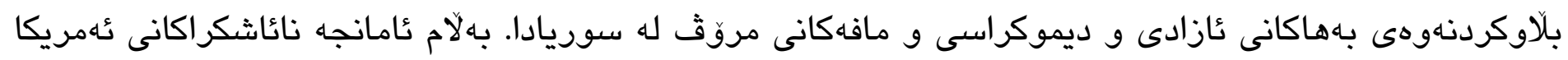

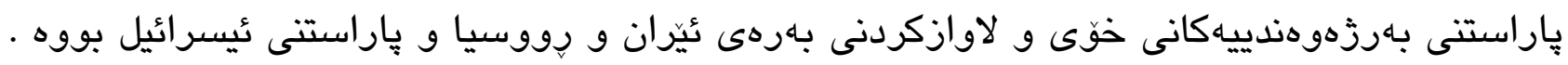

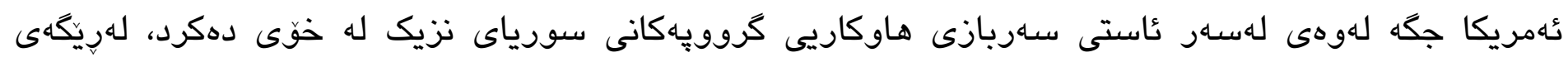

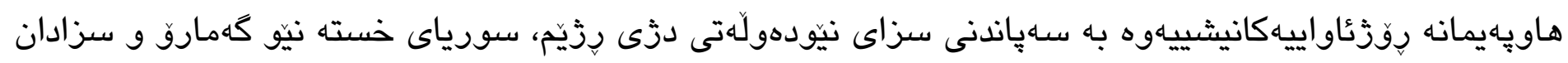

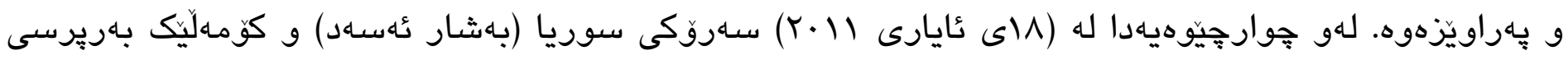

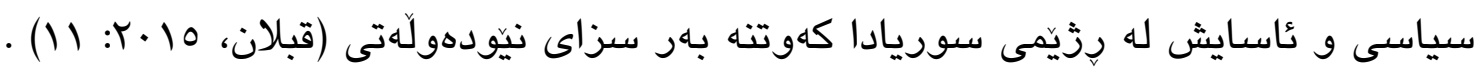

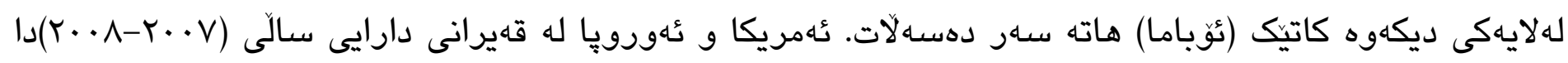

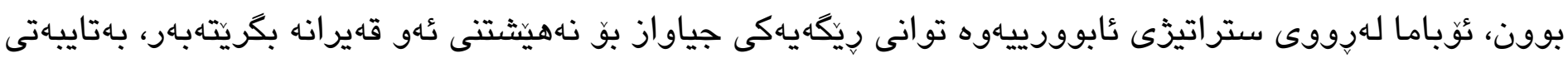

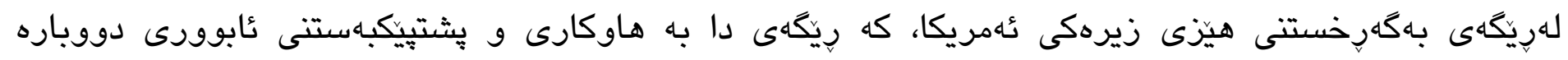

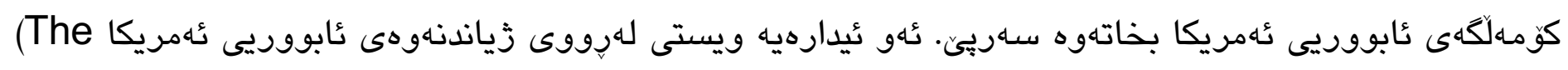

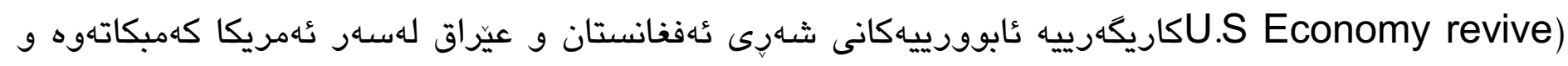

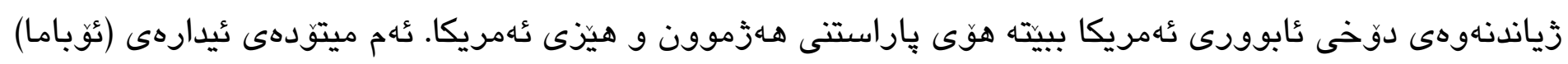

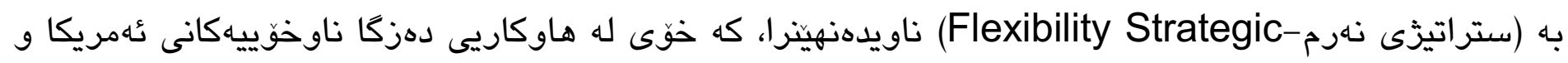

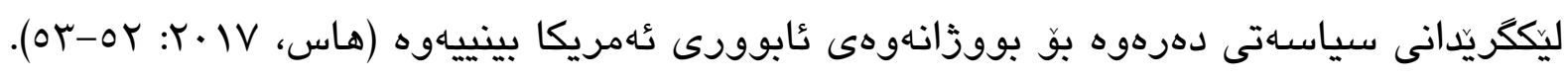




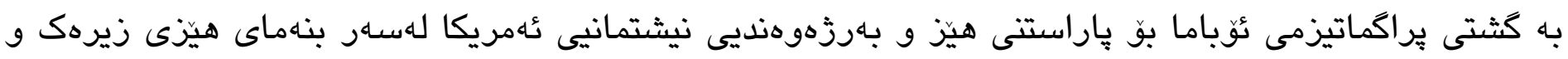

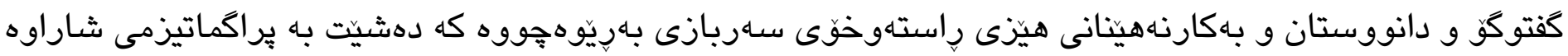
و نهرم ناوى بهينين.

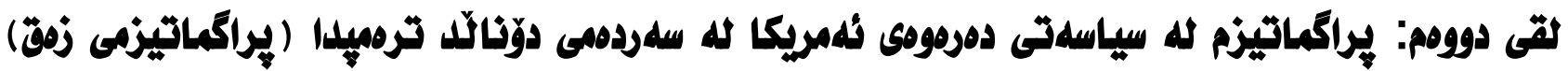

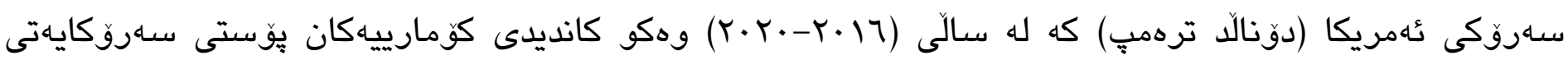

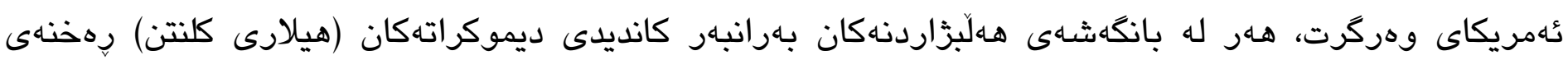

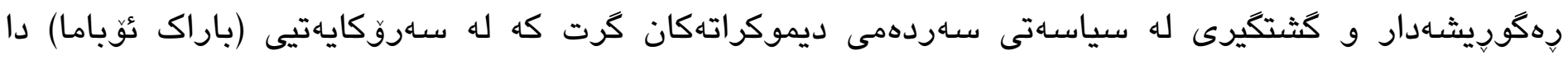
بهرجهاهتبوو .

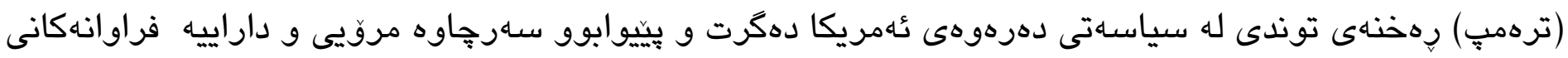

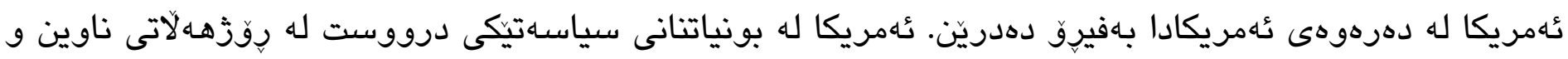

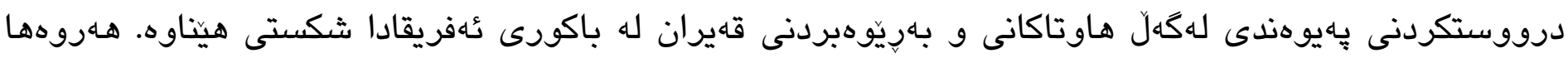

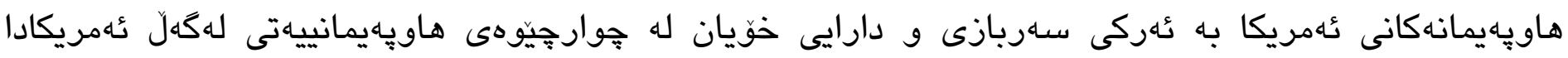

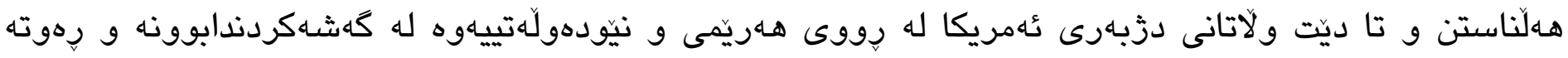

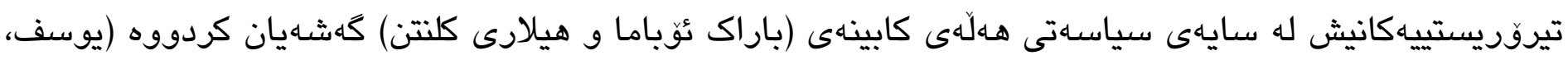
(1) $7: T \cdot 19$

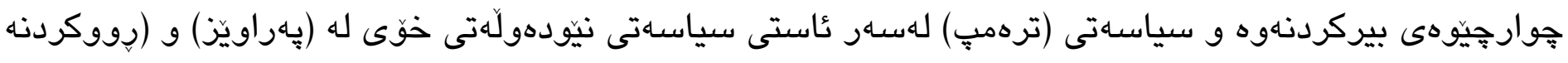

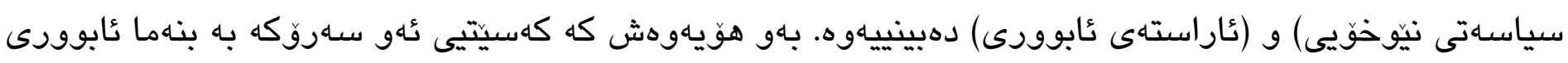

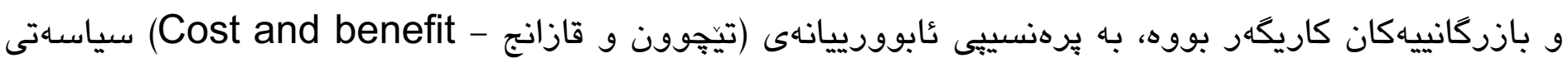

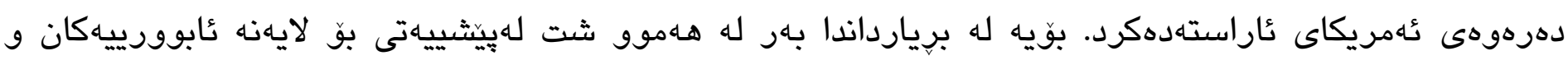

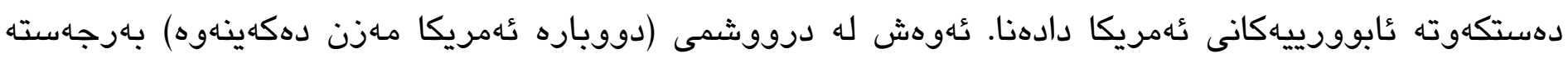

بووبوو.

دهشيت له جهند خاليّكا بِرهنسيِه كثتييهكانى سياسهتى دهرهوهى (دوّنالد ترهمب) بخهينهروو: (مؤلف جماعي، (rq): $:$. IV

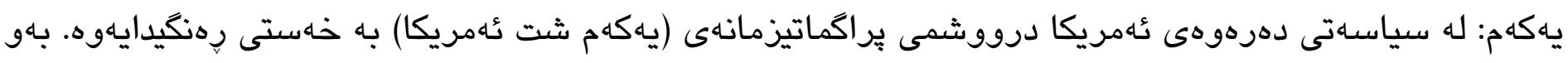

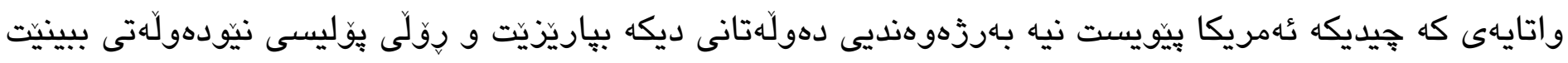

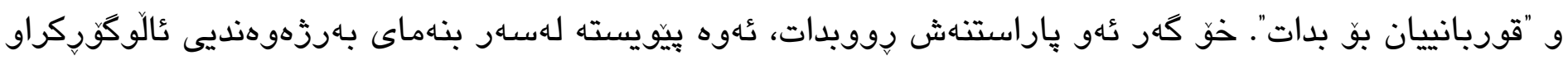

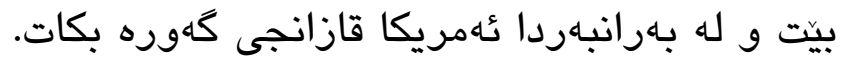




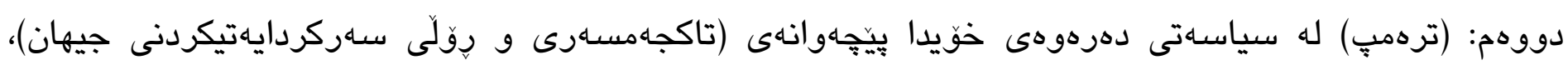

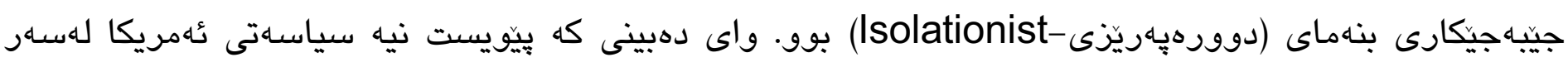

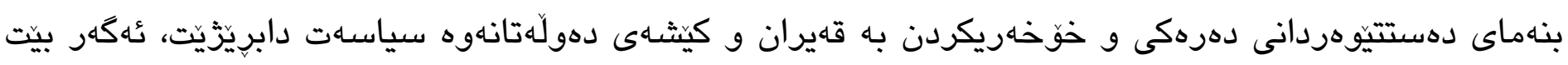

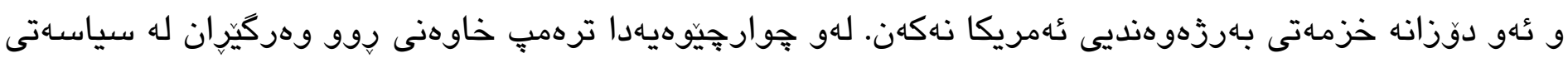

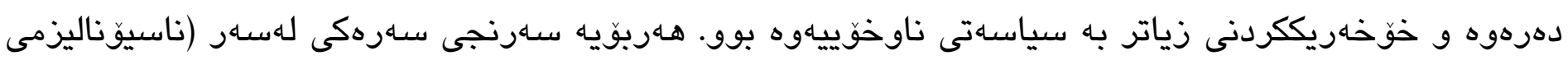

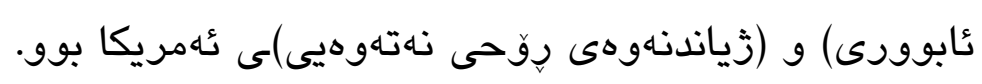

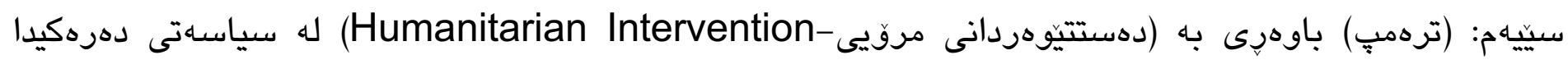

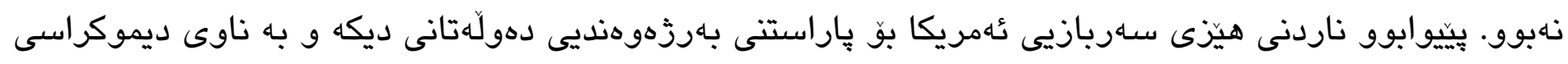

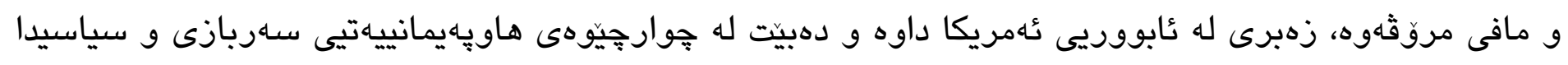

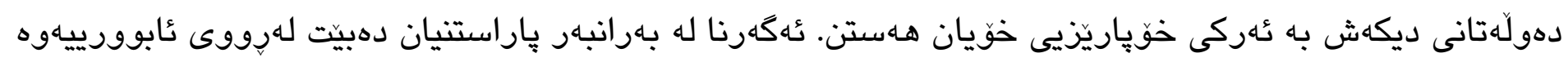
قهرهبووى ئهمريكا بكهنهوه.

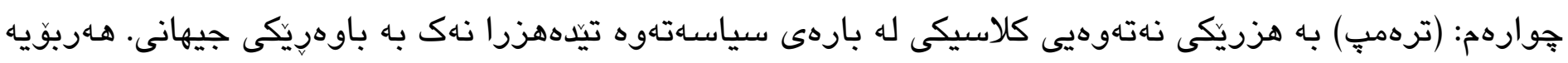

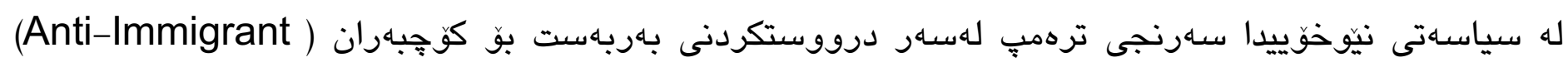
and nativist

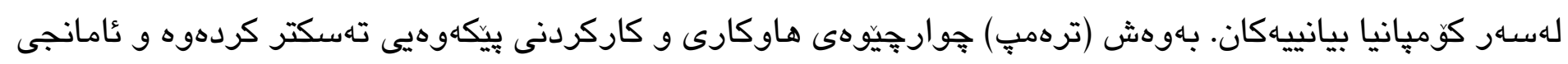

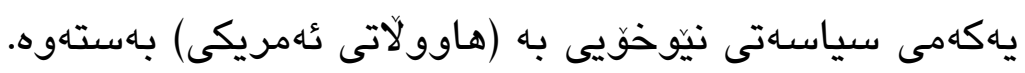

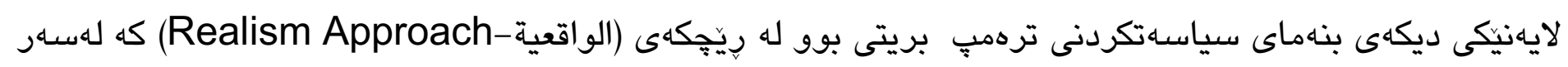

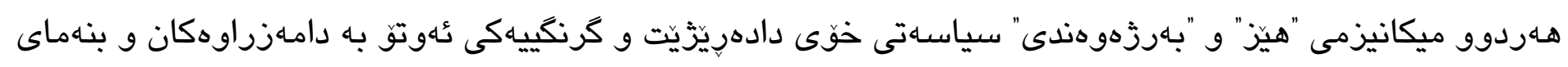

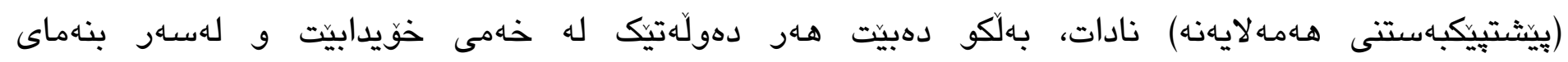

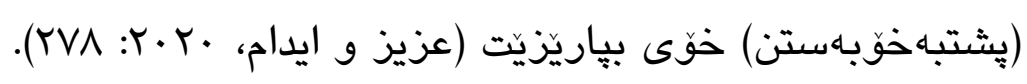

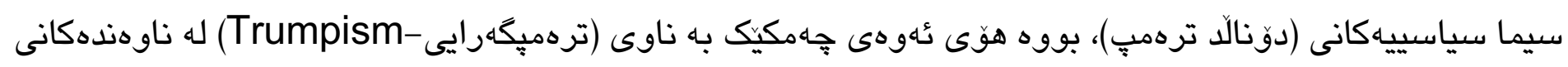

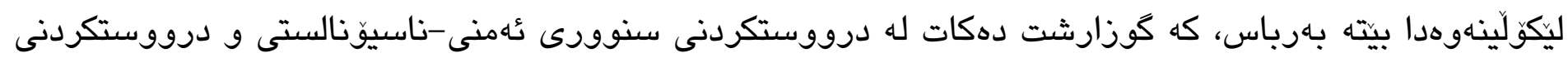

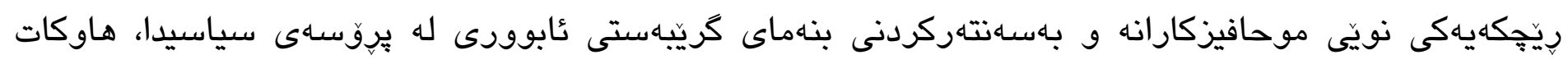

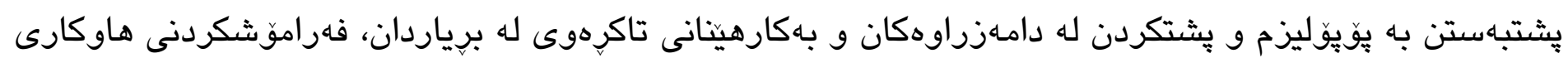

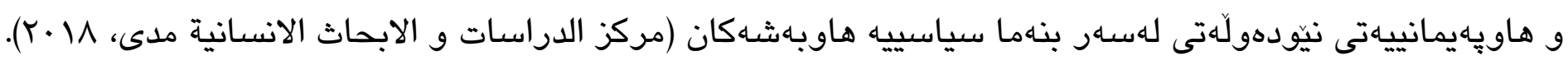

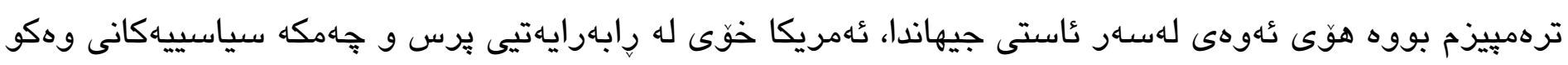

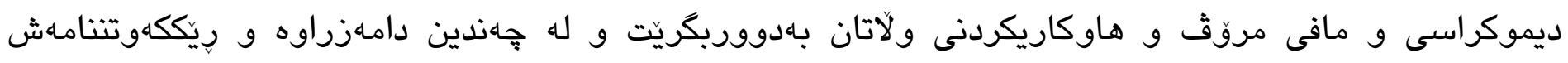

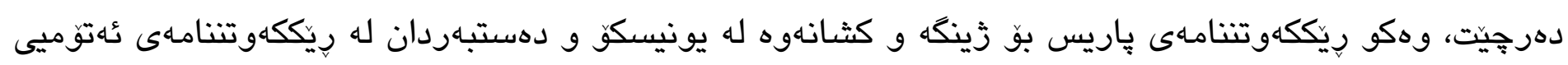




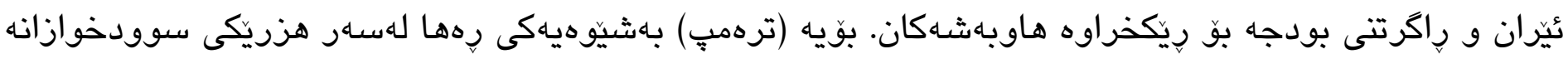

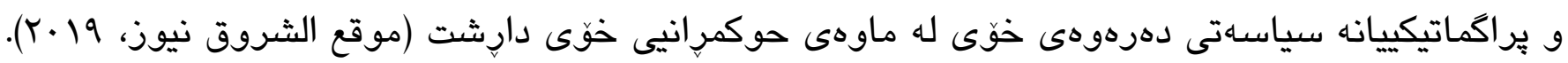

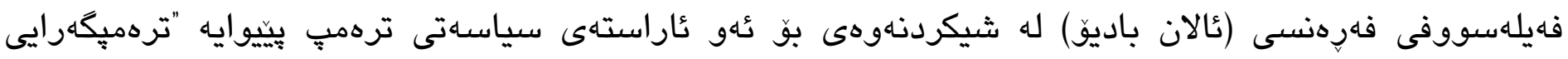

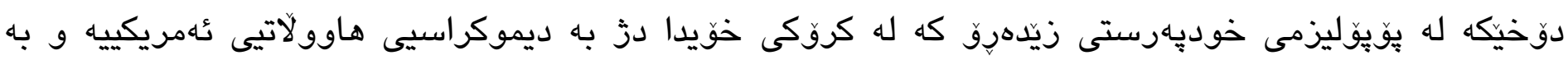

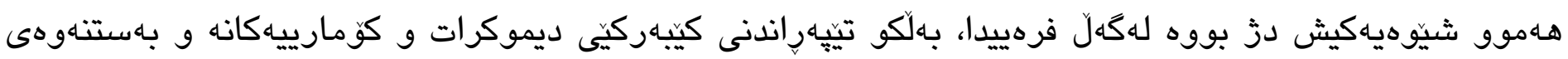

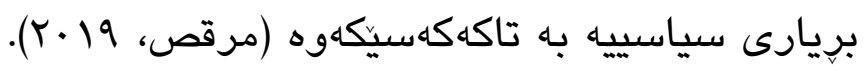

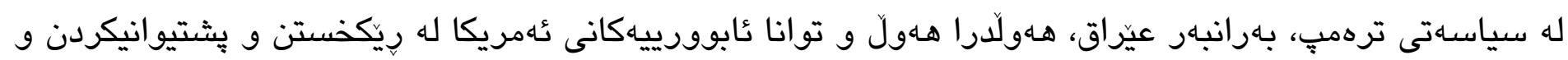

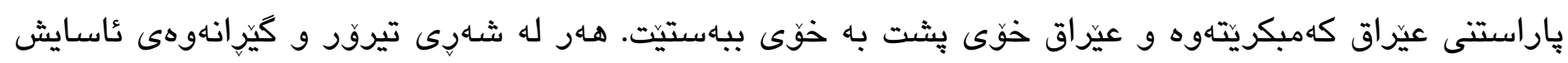

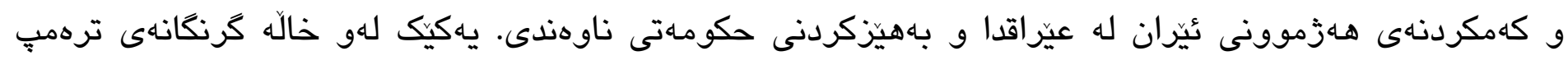

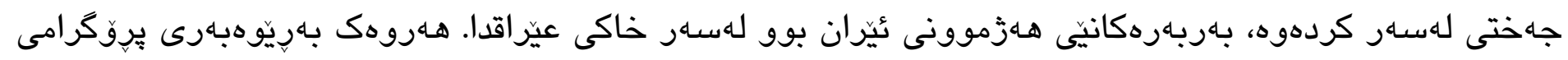

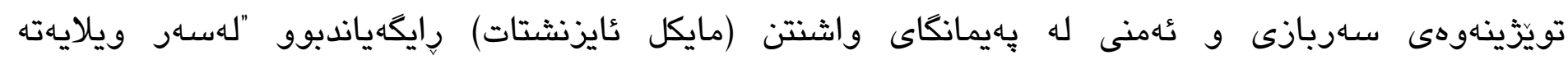

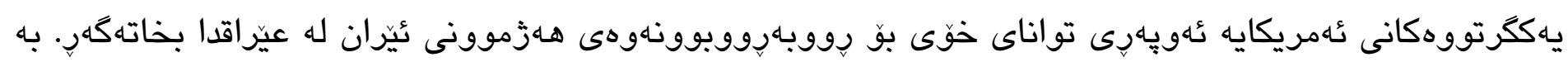

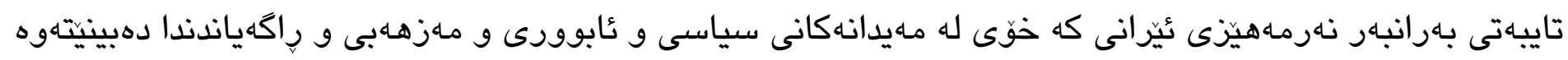

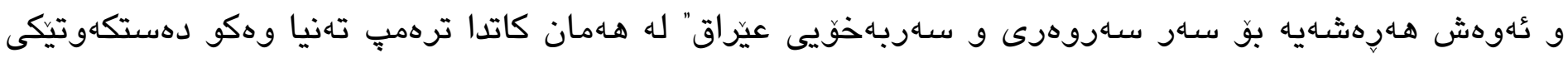

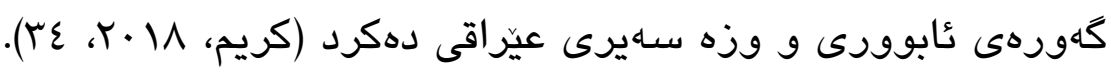

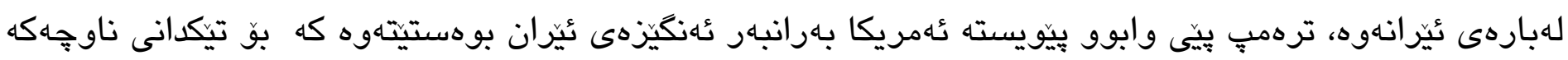

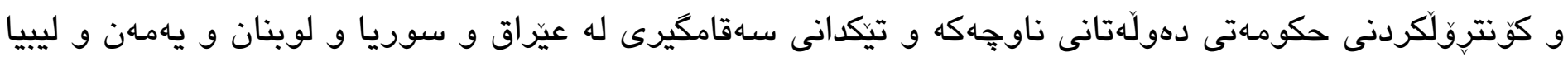

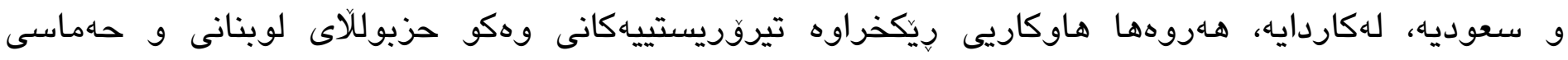

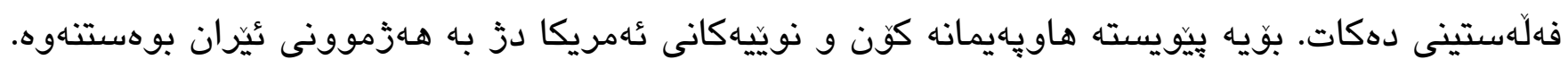

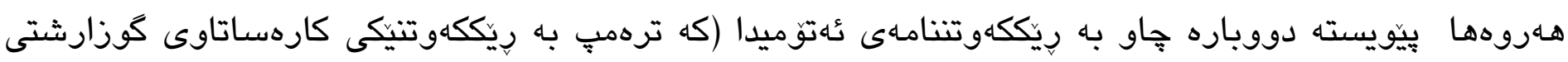

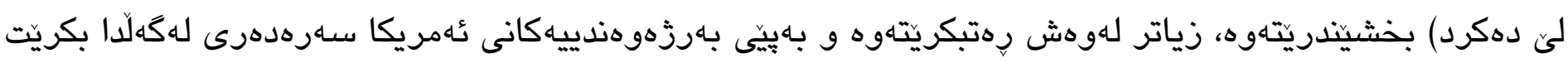

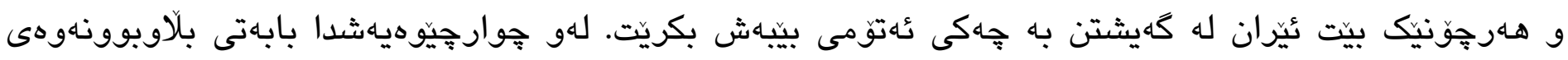

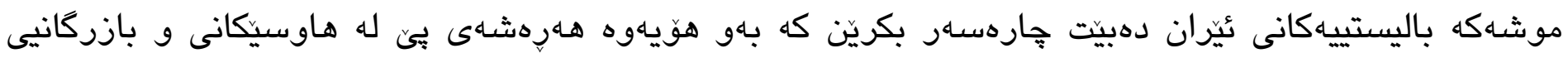

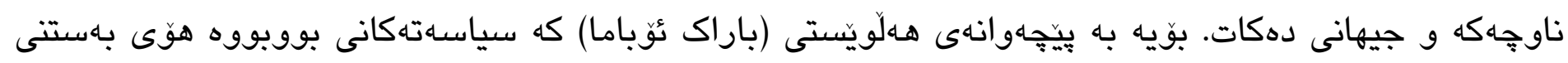

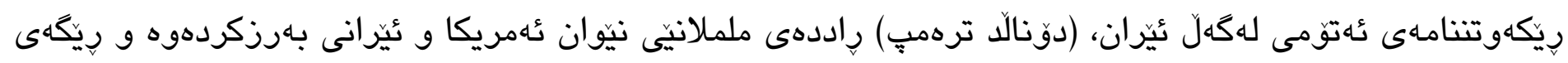

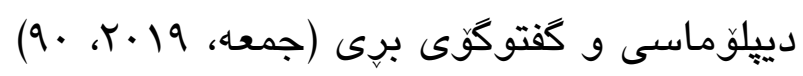

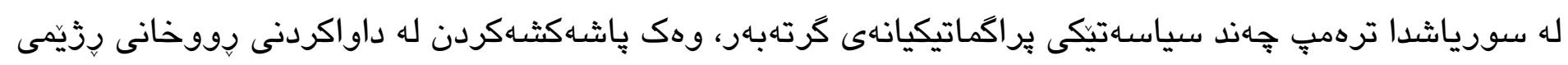

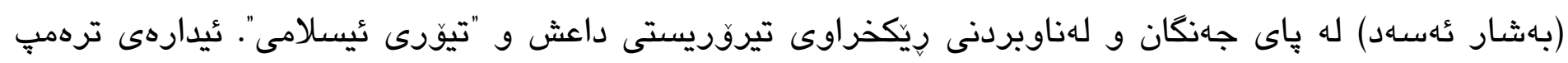




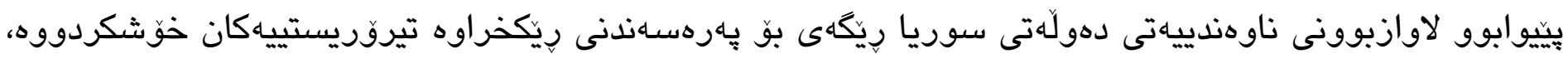

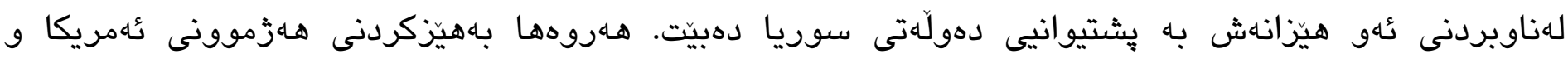

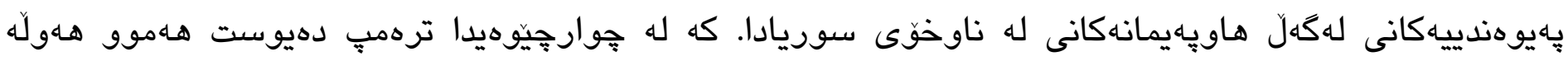

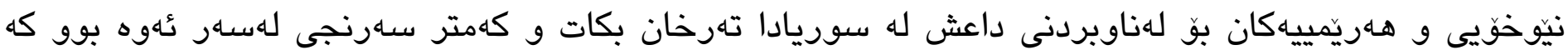

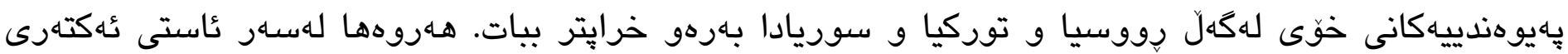

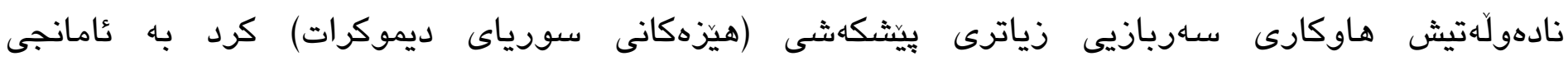

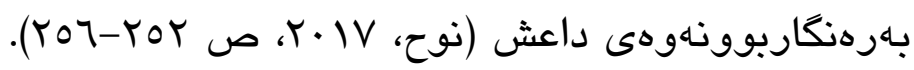

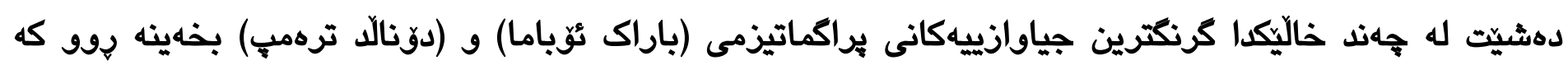
بريتين له:

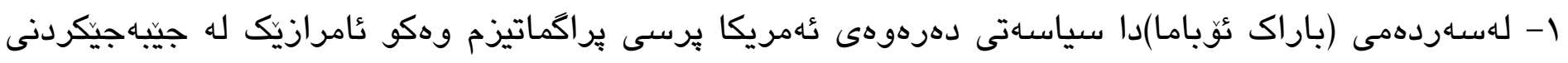

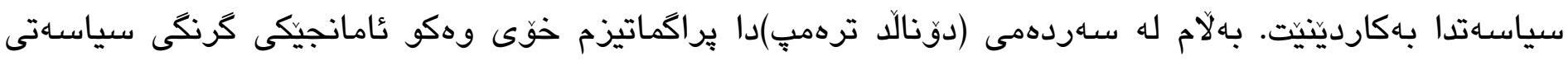

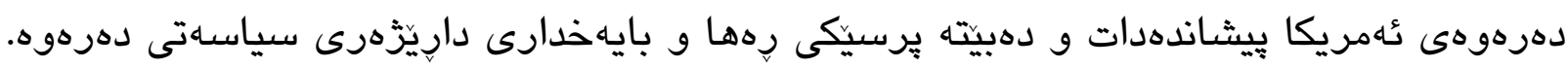

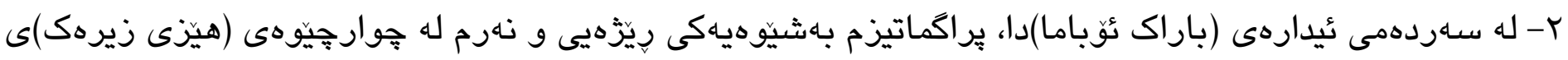

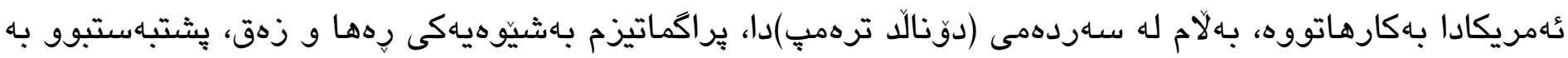

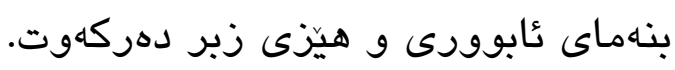

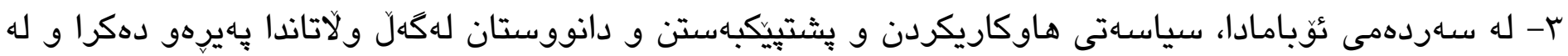

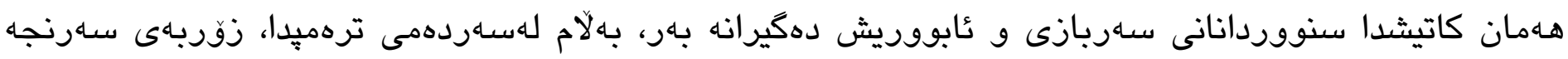

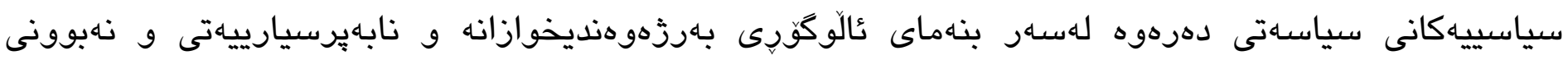

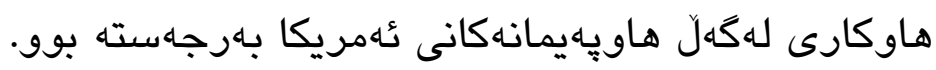

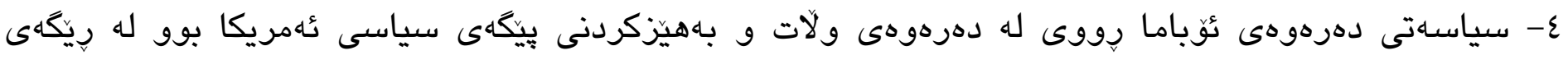

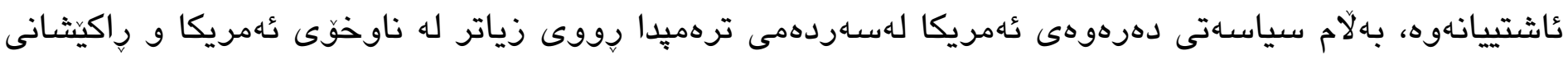
راى كَثتيى عُهمريكا بوو.

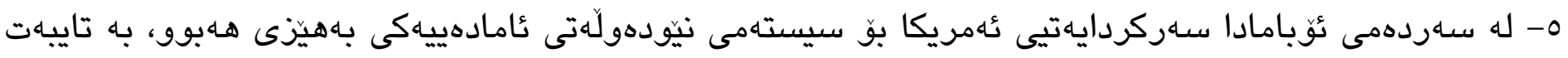

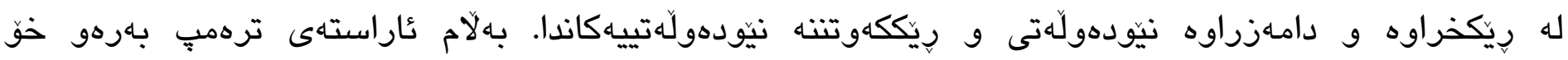

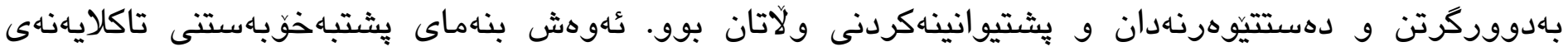
بهاهيزتر و رهوتى سياسهاتى ئهمريكاى زياتر بهردو تاكلايهنى برد. 
له كوتاييدا، دهشيتّ كرنكترين دهرئهنجامهكانى تُهم تويّزينهوهيه لهم خالآنى خوارهوهدا كورت بكهينهوه: 1- له كوتاييهكانى سهدهى نوزده و سهرهتاى سهدهى بيستهما، سهرهالدانى فهلسهفهى براكماتيزم ودكو فهلسهاهيهكى كردارى و ئامانجخواز كه لهسهر بنهماى تاقيكردناهوه و ئهزموونكردن له بيركردنهوه و فهلسهاهى ئهمريكادا دهركهوت. ئهو فهلسهفهيه دهرهنجامى شيّوهى زيانى ئهمريكييهكان و كلتوورى كومهالكَهى ئهمريكى بوو كه كَنكييِّدريكى ساهرهيى عاينده و درووستكردنى ئهنجام و فهلسهفهى كردار بووه.

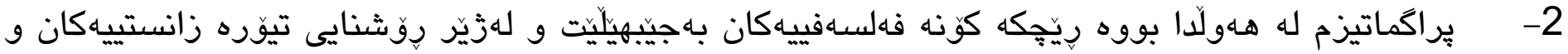

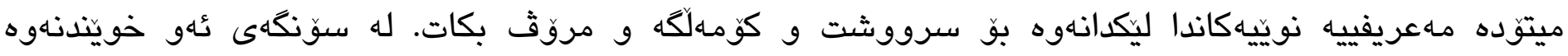
كومهالايهتى و بايلوزّى و دهروونييانهوه، بهى به سرووشتى ململاني و زيندويتيّى بهرزهوهندييهكان و سوودخوازيى مروث بردووه و بوّى ساغ بووهتهوه كه كومهلخكَى مروّيى جكه له ململانييهكى نهبراوه و بهاديهينانى بهرزهوهندييه جوّربه جوّرهانى، شتيكى ديكه نيه.

3- سياسهتى دهرهوهى ئهمريكا به تايبهتى له دواى جهنكى يهكهمى جيهانى و جهنكى دووهمى جيهانى، له زيّر

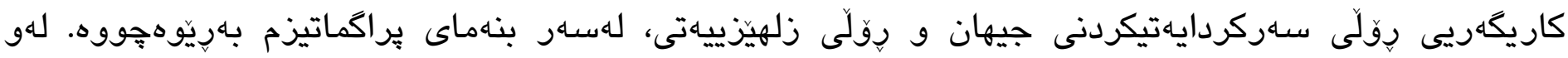

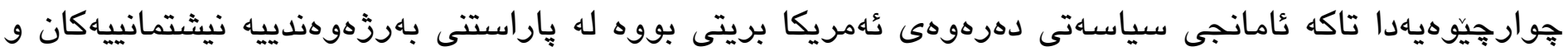

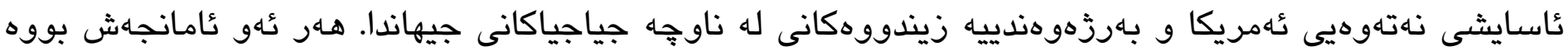
وايكردووه ئهريكا لهسهر ئاستى جيهان وهكو دهولّتيكى فراوانخواز و بههيّز بيريكاتهوه و رِولّى سهركردايهتيكردنى

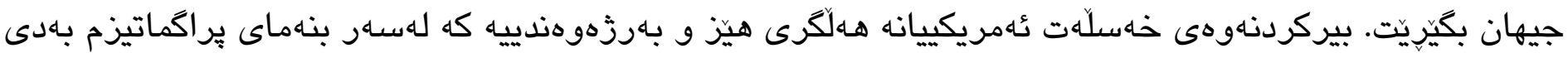
هاتوون.

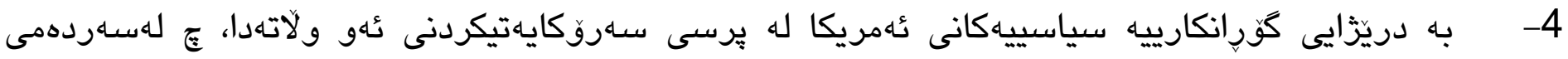
ديموكراتهكان يان كومارييهكاندا بووبيت، كُورانكارى لهسهار ئاستى سهاروكايهتيكردن و تاكتيك و ميكانيزم بهديهاتووه، بهلاّم بههاى نهكَّر بريتى بووه له بهديهينانى ئامانجه ستراتيزييهكانى ئهريكا لهسهر بنهماى سوود و

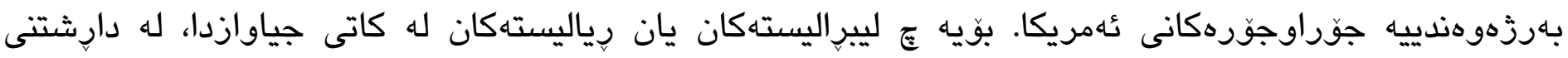

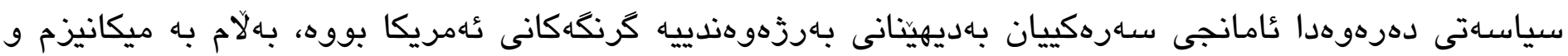
ئامرازى جياوازى سياسهتكردن.

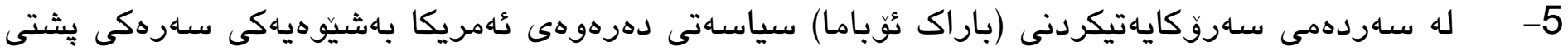

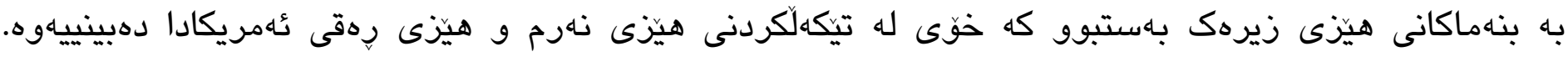
تاقيكردنهوه و ئهزموونكردنى ئهو سياسهاته كومهليكيك بهرزهوهندى و ئامانجى بو ئهمريكا له ماوهى هـاشت سالّى حوكمرانيكردنى (باراك ئوياما) ليكهوتهوه. لهلايهكهوه تاقيكردنهوهى كومهليّك بنهماى سياسى نويى بوو دوور له 


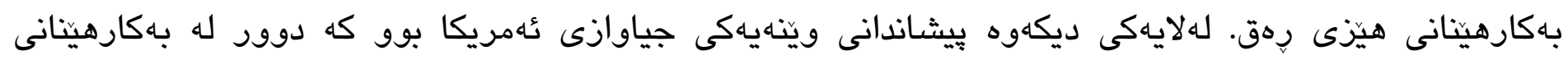

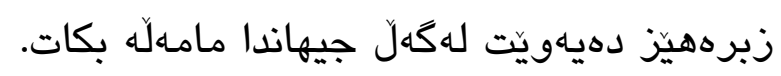

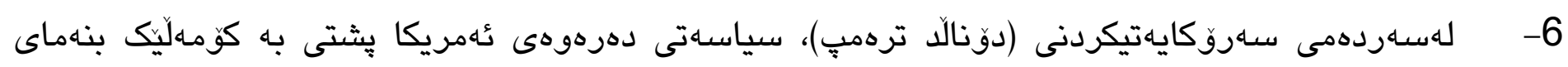

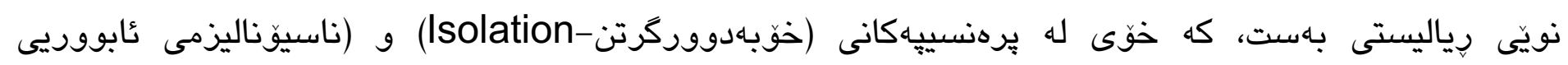

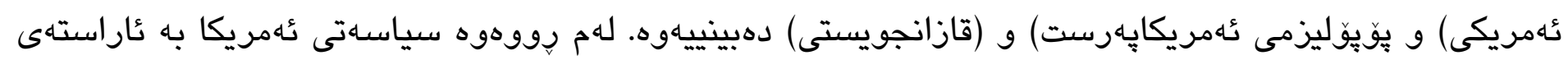

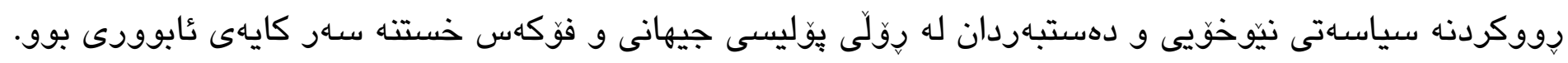

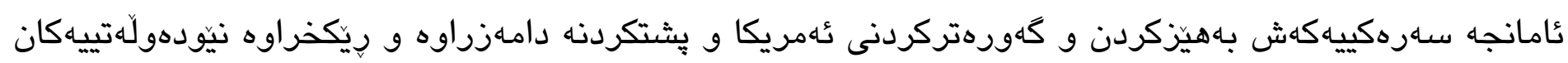

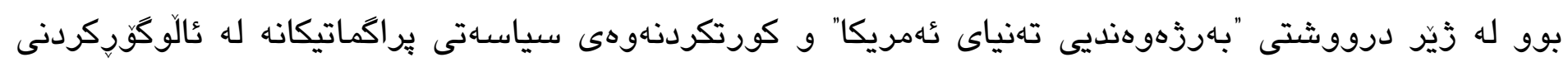
قازانج و سوود لهُّلَ دهولَهتاندا. 


\title{
The Pragmatism of US Foreign Policy in the Obama and Trump Administrations. (Analytical comparative political study)
}

\section{Hema Niazi Hamad}

International Relations \& Diplomacy Department, College Of Political Science, University Of salahaddin, Erbil, Kurdistan Region, Iraq.

E-mail: Hema.niazy@yahoo.com

\begin{abstract}
:
This researched has tried to analyze the philosophy of pragmatics and its development as well as applying it on the level of America's foreign policy in the cabinet of both American Presidents Barack Obama and Donald Trump in a comparative way to analyze and investigate it.

The philosophy of Pragmatics in the center of American policy had an important position in the formulation of foreign policies and decisions and its application between Barack Obama and Donald Trump's administration, was embodied in different forms and mechanisms which understanding this political perspective and direction is helpful to increase an understanding about formulation and application of American foreign policy.

It has been tried to answer the main question of the research within the context of this research, which is how did the main and clear difference of getting benefit from pragmatism between both Obama and Trump's administration has reflected in the American foreign policy?

In the research, it was hypothesized that pragmatism was generally used in American foreign policy to protect America's living interests and applying pragmatism between each Obama and Trump's administration and how it is reflected in American foreign policy.

This research has reached the conclusion that pragmatism in the era of Barak Obama's administration has embodied itself in the form of a clever and hidden soft Power that has not ignored actors and other parties in the international arena despite the desire to protect American interests. But in Donald Trump's era, pragmatism has applied itself in the form of hard, obvious pragmatism, economic, and political interests of America, which was the main desire to protect America's interests.
\end{abstract}

Keywords: Pragmatism, Foreign Policy, Barack Obama, Donald Trump. 
فهردج، ئهنوهر محهمهد (T/ (Y)، تيوّى رياليزم له بهيوهندييه نيّودهولَهتيهكاندا، و: خهليل كهريم محهمهد و ئهمهد عهلى ئهمهد، سليمانى، دهزكاى روشنبيريى جهمال عيرفان.

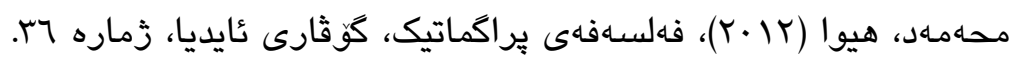
احلام، بن سلامة (17 (Y)، أصول فلسفة التربية عند جون ديوي (رسالة ماجستير)، كلية العلوم الانسانية و الاجتماعية، جامعة محمد بوضياف.

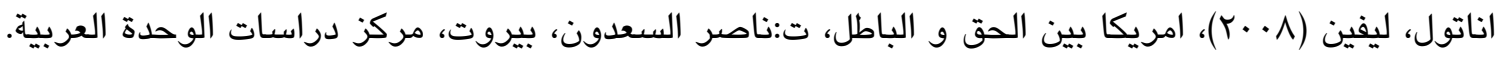
بلاتونوف، أوليغ (Y..r)، لهذا كلة ستنقرض أمريكا (الحكومة العالمية الخفية)، ت:أئلة موسى و ايرنيا بولمشينكايا، دمشق، ط:الاولى، دار الحصارد للطباعة و النشر. الجاسور، ناظم عبدالواحد (ع . +؟)، موسوعة علم السياسة، ط الاولى، عمان، دار مجدلاوي للنشر و التوزيح.

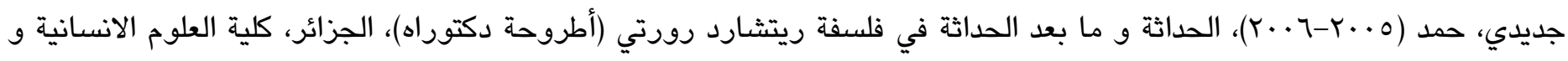
العلوم الاجتماعية، جامعة منتوري قسنطينة. جرجس، فواز (عا.r)، أوباما و الثرق الأوسط: مقاربة بين الخطاب و السياسات، ط:الثاني، ابوظبي، مركز الامارات للدراسات و

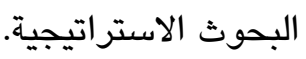
جلال، شوقي (·(1)، العقل الامريكي، القاهرة، الهيئة المصرية العامة للكتاب. جمعة، فادي (V) (Y)، العلاقات الامريكية و تداعياتها على منطقة الشرق الأوسط، ط:الاولى، القدس، دار الفكر للطباعة و النشر و التوزيع. جونسن، لويد (1919)، تفسير السياسة الخارجية، الرياض.

جيمس، وليام (^• •r) البراجماتية، ترجمة محمد علي العريان، تقديم زكي نجيب محمود، القاهرة، المركز القومي للترجمة. جيمس، وليام (بدون سنة)، بعض مشكلات الفلسفة، ت: محمد فتحي الشنيطي، المؤسسة المصرية العامة للطباعة و النشر. جيمس، وليم (ع|·r)، البراغماتية، ت: وليد شحادة، دمشق، دار الفرقد الطباعة و النشر. الحجيلي، منصور بن عبدالعزيز (بدون سنة)، البراجماتية: عرض و نقد، السعودية، جامعة طيبة.

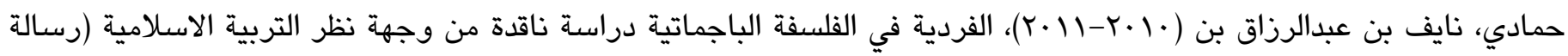
ماجستير)، كلية تربية، جامعة أم القرى. حميد، نزار نجيب (rا (Y)، الذريعة في الفلسفة البراكماتية و انعكاسها على السياسة الخارجية الامريكية في القرن الحادي و العشرين، الموصل، مجلة كلية العلوم الاسلامية في جامعة الموصل، عددعا. 
خدومة، بالهواري (10 •Y-7 • (Y) أسس المذهب البراجماتي وليام جيمس نموذجا (رسالة ماجستير)، كلية العلوم الاجتماعية و الانسانية، جامعة الدكتور مولاى الطاهر. دشر، ميثاق مناحي (17 • (Y)، النظرية الواقعية: دراسة في الاصول و الاتجاهات الفكرية الواقعية، مجلة أهل البيت، العدد •r. راسل، برتراند (19VV)، تاريخ الفلسفة الغربية ، ت: فتحي شنيطي، الهيئة المصرية العامة للكتاب. الرمضاني، مازن اسماعيل، السياسة الخارجية، بغداد، جامعة البغداد.

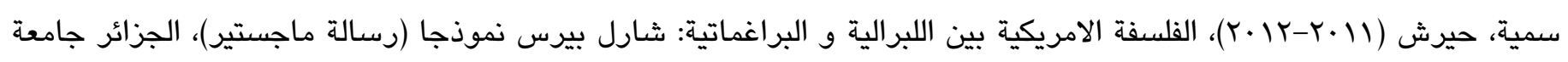
وهران، كلية العلوم الاجتماعية.

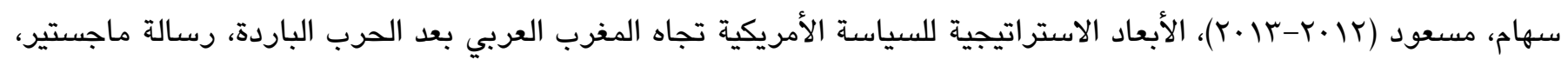
مستغانم، جامعة عبدالحميد بن باديس. شكري، فايزة أنور(|(1)، القيم الأخلاقية، الاسكندرية، دار المعرفة الجامعية للنشر. شيباني، اناس (1/ •r -19 •r) في تحليل السياسة الخارجية: النماذج النظرية بين ضرورات التعدد و مساعي التكامل (اطروحة دكتوراه)، ، باتنة، جامعة الحاج لخضر.

الصباغ، عبداللطيف (ع (Y)، العلاقات الدولية، ط:الاولى، بنها. الصفار، ايناس مهدي ابراهيم (ع (†)، ابعاد الفكر البرجماتي في فن الباوهاوس، مجلة جامعة بابل، المجلد بr، العدد 0. الطويل، توفيق (س (1901)، مذهب المنفعة العامة في فلسفة الأخلاق، ط: الأولى، القاهرة.

العادي، سالم حسين رمضان (T/ (Y)، الذرائعية كأداة تحليل للخطاب السياسي الأمريكي، مجلة الساتل العلمية المحكمة، العدد IV. عزيز و ايدام، عباس هاشم سعد رزيح (عا •r)، السياسة الخارجية الامريكية ازاء منطقة الشرق الاوسط في عهد الرئيس دونالد ترامب و افاقها المستقبلية، بغداد، جامعة بغداد.

قبلان، مروان (10 • ب)، المسألة السورية و استقطاباتها الاقليمية و الدولية، الدوحة،المركز العربي للابحاث و دراسة السياسات.

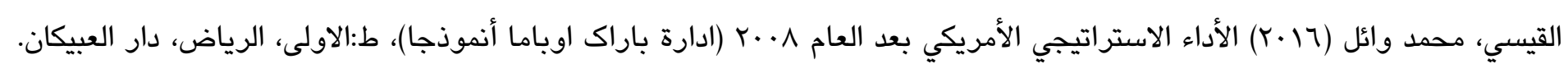
كاظم، رائد جبار (·r·r) الفلسفة البرجماتية: نقد الفهم السائد، موقع الالكتروني شبكة النبأ، على الرابط الاتي: https://annabaa.org/arabic/authorsarticles/22246

كريم، منصور أبو (V) (Y)، أبرز ملامح السياسية الخارجية الأمريكية تجاه منطقة الشرق الأوسط بعد فوز ترامب، غزة، مركز رؤية للدراسات و الأبحاث. كلارك، ويسلي (ع •.ب)، الانتصار في الحروب الحديثة: العراق و الارهاب و الامبراطورية الأمريكية، ت: عمر الايوبي، دار الكتاب العربي. 


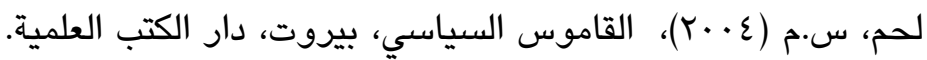

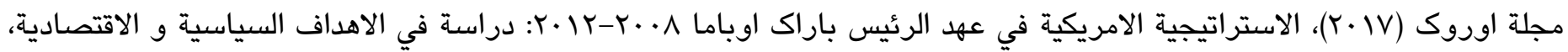

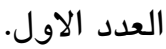

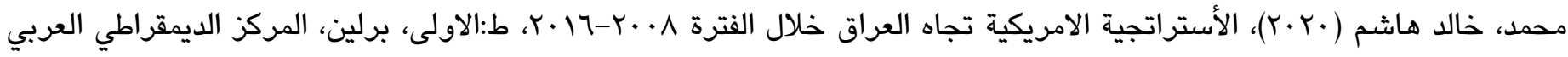
للدراسات الاستراتيجية و السياسة و الاقتصادية.

محمود، زكي نجيب (س (199)، من زاوية الفلسفة، ط: الرابعة، القاهرة، دار الشرق.

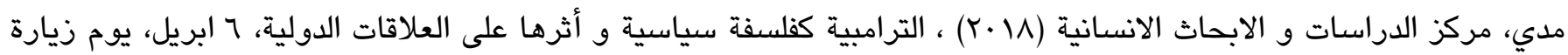

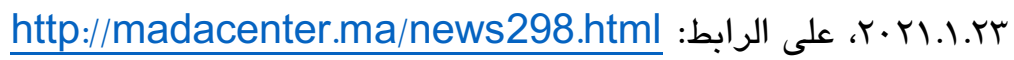

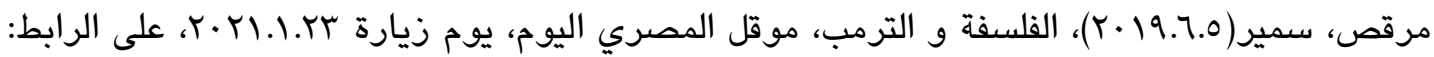
https://www.almasryalyoum.com/news/details/1402727

مقلد، اسماعيل صبري (19V1) العلاقات السياسية الدولية، دراسة في الأصول و النطريات، الكويت: مطبوعات جامعة الكويت. ممدوح، مجدي (YV)، الداروينية الاجتماعية: منطلقاتها النظرية و اعلامها، اردن، مجلة افكار، عدد7. المهرج،، علي عبدالهادي (^^ •r)، الفلسفة البراجماتية: اصولها و مبادئها، ط: الاولى، بيروت، دار الكتب العلمية. الموساوي، عبدالحميد العيد (ع اب)، العلاقات الأمريكية الايرانية في عهد الرئيس أوباما، بغداد، مركز الدراسات الاستراتيجية و الدولية.

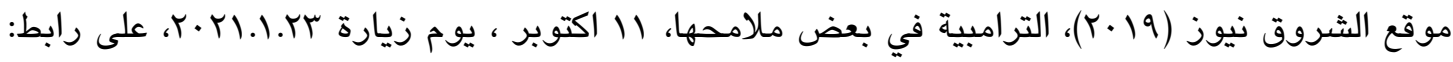
https://www.shorouknews.com/columns/view.aspx?cdate=11102019\&id=871ca0c9-ec9d-42ee-a5db-

مؤلف جماعي (VIV)، الشرق الاوسط في ظل اجندات السياسة الخارجية الامريكية، ط: الاولى، برلين، المركز الديمقراطي العربي للدراسات الاستراتيجية و السياسية و الاقتصادية. النعيمي، أحمد نوري (1991)، السياسة الخارجية، ط: الاولى، بيروت، دار السنهورى.

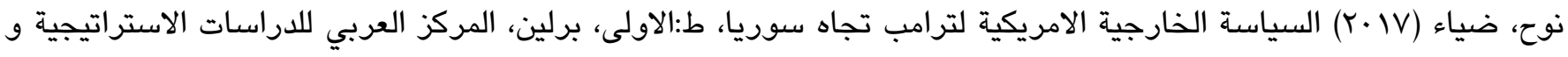
السياسة و الاقتصادية.

هاس، ريتشارد (V +. ()، الفرصة: لحظة أمريكا لتغيير مجرى التأريخ، ت: أسعد كامل الياس، ط:الاولى، الرياض، دار العبيكان. وين، رالف ن • (ع797)، قاموس جون ديوي للتربية ، ت: محمد علي عريان، القاهرة، مؤسسة فرانكلين للطباعة و النشر. يوسف، ليث بدر الخطاب (9 (r)، الاعلامي للرئيس ترامب في الانتخابات الامريكية، ، بغداد.، مجلة باحث الاعلامي، العدد rع. 
Barbalet, Jack William James (2004), Pragmatism, Social Psychology and Emotions, European Journal Of Social Theory, London, 7(3).

Cambridge Dectionary:from:

https://dictionary.cambridge.org/dictionary/learner-english/pragmatism

James, William (1907), Pragmtism : A new name for some old ways or thinking.

james, william What Pragmatism Means, distinguishes two different but interrelated stands of pragmatism:a theory of meaning and theory of truth, Rydenfelt.

Khan, Ismail (2013), The Obama Doctrine- a multipolar foreign policy (Research paper), linneuniversitet university. Lacey, A.R. (2005), A dictionary of Philosophy, Department of Philosophy, King's College, New York M.McCormick, James(2011), The Obama Presidency: A Foreign Policy of Change?, Jowa State University Nubiola, Jaime C.S. Peirce (1996): Pragmatism and logicism,Philosophia Scientice, University of Navarra. Oxford Dectionary(2008), from https://www.oxfordlearnersdictionaries.com/definition/english/pragmatism?q=pragmatism 